\title{
In-Tank Processing (ITP) Geotechnical Summary Report
}

by

R. J. Cumbust

Westinghouse Savannah River Company

Savannah River Site

Aiken, South Carolina 29808

L. A. Salomone

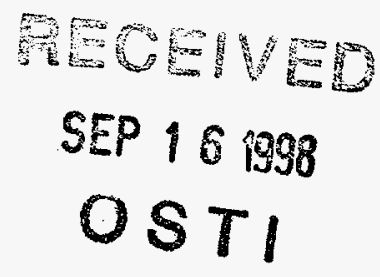

DOE Contract No. DE-AC09-89SR18035

This paper was prepared in connection with work done under the above contract number with the U.S.

Department of Energy. By acceptance of this paper, the publisher and/or recipient acknowledges the U. S.

Government's right to retain a nonexclusive, royalty-free license in and to any copyright covering this paper, along with the right to reproduce and to authorize others to reproduce all or part of the copyrighted paper. 


\section{DISCLAIMER}

This report was prepared as an account of work sponsored by an agency of the United States Government. Neither the United States Government nor any agency thereof, nor any of their employees, makes any warranty, express or implied, or assumes any legal liability or responsibility for the accuracy, completeness, or usefulness of any information, apparatus, product, or process disclosed, or represents that its use would not infringe privately owned rights. Reference herein to any specific commercial product, process, or service by trade name, trademark, manufacturer, or otherwise does not necessarily constitute or imply its endorsement, recommendation, or favoring by the United States Government or any agency thereof. The views and opinions of authors expressed herein do not necessarily state or reflect those of the United States Government or any agency thereof.

This report has been reproduced directly from the best available copy.

Available to DOE and DOE contractors from the Office of Scientific and Technical Information, P.O. Box 62, Oak Ridge, TN 37831; prices available from (615) 576-8401.

Available to the public from the National Technical Information Service, U.S. Department of Commerce, 5285 Port Royal Road, Springfield, VA 22161. 


\section{DISCLAIMER}

Portions of this document may be illegible in electronic image products. Images are produced from the best available original document. 
1194 $00 \quad 742424$

WSRC-TR-94-0369

REV. 0

JULY 1994

\section{INFORMATION ONLY}

Site Geotechnical Services (SGS)

In Tank Processing (ITP) Geotechnical Summary Report (U)

Site Geotechnical Services Department

Westinghouse Savannah River Company

Savannah River Site

Aiken, SC 29808

PREPARED FOR THE U.S. DEPARTMENT OR ENEROY UNDER CONTRACT DE-ACO9-89R18035
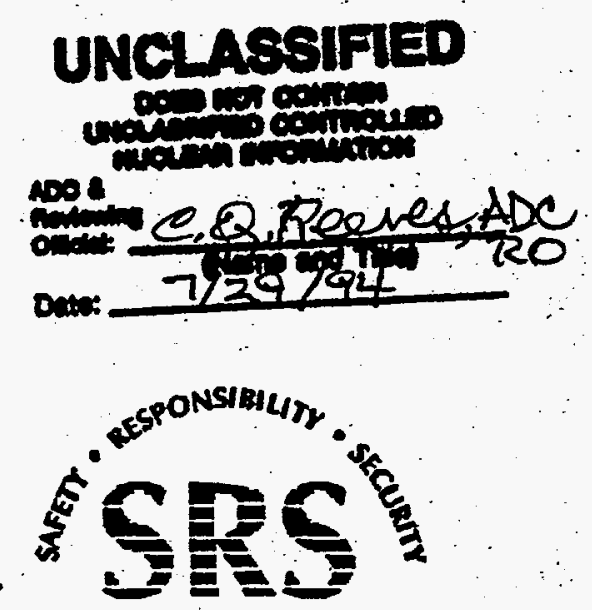

SAVANNAH RIVER SITE 
Site Geotechnical Services
In Tank Processing (ITP) Geol

In Tank Processing (ITP) Geotechnical Summary Report

WSRC-TR-94-0369, Rev. 0

july 29, 1994

Project: In Tank Processing (TTP) Facility

Document: WSRC-TR-94-0369, Rev. 0

Title: In Tank Processing (TTP) Geotechnical Summary Report (U)

Approvals:

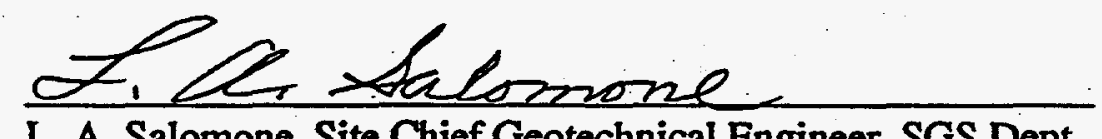

L. A. Salomone, Site Chief Geotechnical Engineer, SGS Dept. $\frac{7 / 29 / 94}{\text { Date: }}$ 


\section{TABLE OF CONTENTS}

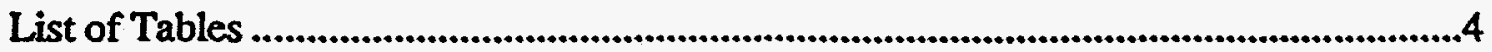

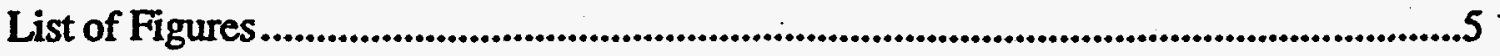

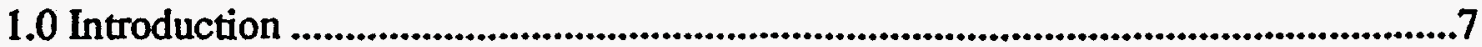

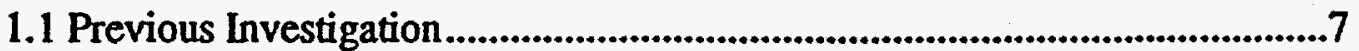

1.1.1 "High Level Waste Storage Tanks Nos. 48 through 51 Raymond International Inc., 1976; Mueser et. al., 1977)"............................7

1.1.2 "New High Level Waste Storage Tanks Nos. 50 and 51 (Mueser et. al., 1978)"'.............................................................8

1.1.3 "In-Tank Precipitation Facility (Mueser et al., 1984a)" .................8

2.0 Seismology and Geology 8

2.1 Summary of Parameters Associated with the Development of the EBE Soil Spectra

2.1.1 Source Parameters. 8

2.1.2 Structure $Q$

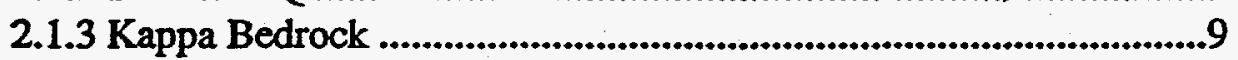

2.1.4 Soil Model.................................................................................9

2.2 ITP Median and 84th Percentile Rock Motions ..........................................9

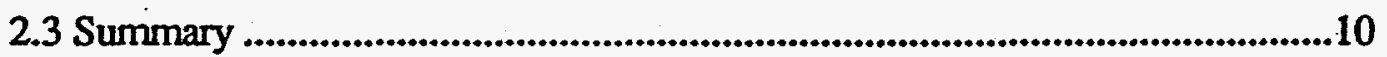

2.4 Introduction Calcareous Sequences Beneath the GSA .................................10

2.5 Carbonate Stratigraphy ..........................................................................10

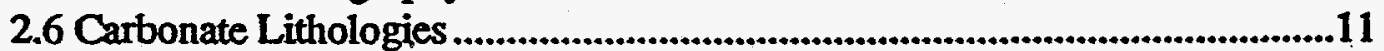

2.7 "Loose Zones" in the GSA Area ............................................................ 12

2.8 Faulting Associated With Carbonate Buildups .........................................13

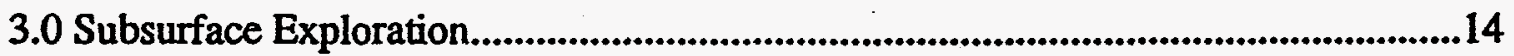

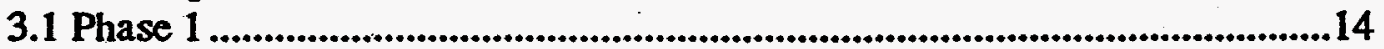

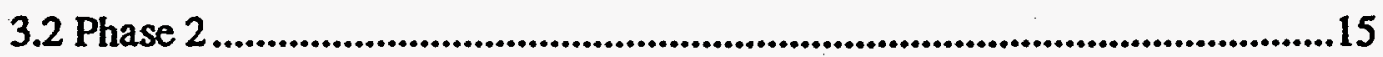

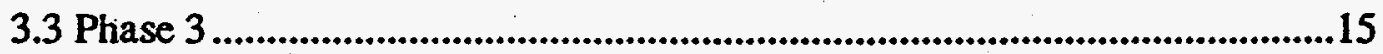

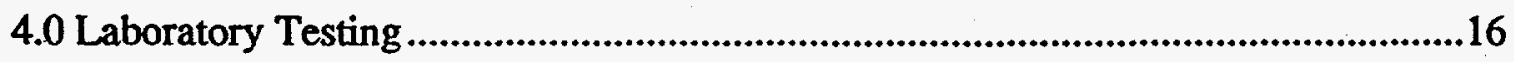

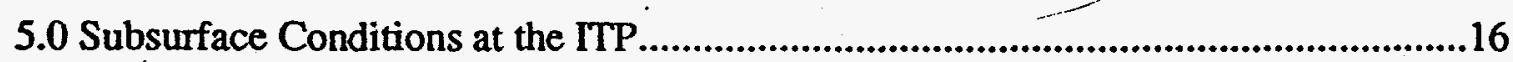

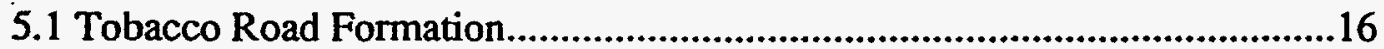

5.2 Dry Branch Formation ..........................................................................17

5.3 Santee Formation .................................................................................17

5.4 Soft Zones in the Dry Branch and Santee Formations ................................18

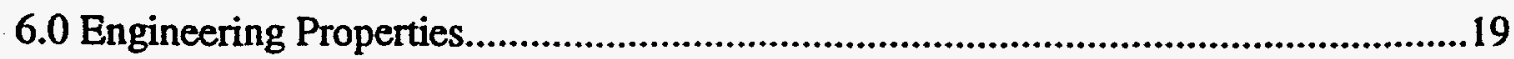


7.0 Engineering Analyses..........................................................................................19

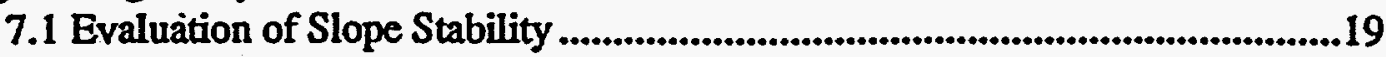

7.1.1 Static Factors of Safety...............................................................20

7.1.2 Pseudo-Static (Short Term) Analysis .............................................20

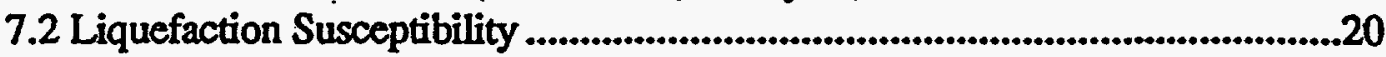

7.2.1 Criteria for Clayey Soils...................................................................20

7.2.2 Shear Wave Velocity Approach .......................................................21

7.2.3 Performance of Old Sand Deposits ...................................................22

7.2.4 The Stress Method ......................................................................................23

7.2.5 The Strain Method .................................................................................24

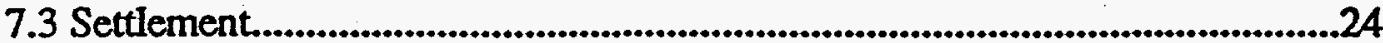

7.3.1 Dynamic Settlement Due to Dissipation of Seismically-Induced Pore Pressure .................................................................................24

7.3.2 Static Settlement Due to Tank Loading During Operation and :-

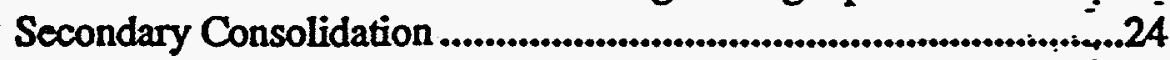

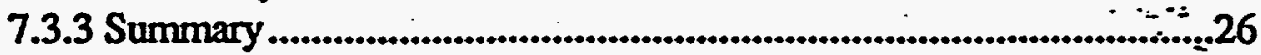

7.4 Worst Case Settlement...........................................................................26

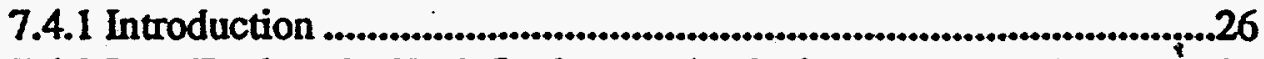

7.4.2 Post-Earthquake Tank Settlement Analysis....................................27

7.4.3 Worst Case Settlement Estimates: Summary ..................................28

8.0 Conclusions

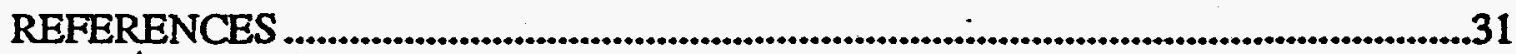

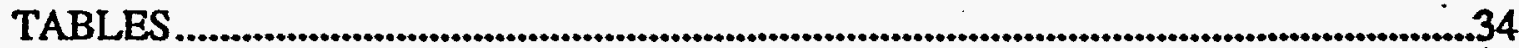

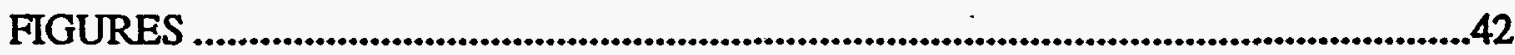




\section{LIST OF TABLES}

Table 2-1 Chronology of Geologic Events Showing the Depositional History in the Vicinity of the $\mathrm{H}$-Area Tank Farm

Table 4-1 Triaxial Laboratory Testing Program

Table 6-1 Average Soil Properties for ITP Facility

Table 7-1 Best Estimate Shear Strength Parameters for Slope Stability Analysis

Table 7-2 Average and Normalized Shear Wave Velocities for the ITP Soil Column

Table 7-3 Soil Parameters Used in Settlement Analysis (after Mueser et al., 1984b)

Table 7-4 Tank Settlement 


\section{LIST OF FIGURES}

Figure 2-1 Comparison of the Smoothed 5\% Damped Distant Event K-Reactor Soil Response Spectrum (ITP Interim Soil Spectrum), K-Reactor Local Event Spectrum, and the Blume (1982) Envelope Spectrum.

Figure 2-2 Comparison of the 5\% Damped IIP Interim Rock Response Spectrum to the 50th and 84th Percentile Rock Spectra Developed for the ITP.

Figure 2-3 Isopach Map of Calcareous Sediments in the GSA

Figure 2-4 Comparison of Nomenclature

Figure 2-5 Map of Shelfal relief Around Cape Canaveral, Florida. Modem Analog for Depositional Setting of the Santee Limestone After Field and Duane, 1974.

Figure 2-6 Drilling Data for Well BGX-4A

Figure 2-7 ITP Correlation Panel Hung on 330' Elevation. Curves are Gamma-ray or Tip Resistance

Figure 2-8 Elevation of Tobacco Road Top Near ITP

Figure 3-1 Boring Exploration Plan

Figure 5-1 Subsurface Profile A - A'

Figure 5-2 Subsurface Profile B - B'

Figure 5-3 Idealized Facies Map of the Upper Santee Formation

Figure 6-1 Idealized Cross Section Showing Mean Shear Wave Velocities, Poisson's Ratios, and Unit Weights for Each Formation.

Figure 7-1 Cross Section 1 Embankment Fill

Figure 7-2 Variation of Permanent Displacement with Yield Acceleration

Figure 7-3a Chinese Criteria for Clayey Soils

Figure 7-3b Chinese Criteria for Clayey Soils

Figure 7-3c Chinese Criteria for Clayey Soils

Figure 7-3d Chinese Criteria for Clayey Soils

Figure 7-3e Chinese Criteria for Clayey Soils

Figure 7-4

Figure 7-5

Figure 7-6

Cyclic Stress Ratio versus Modified SPT N Value $\left(\mathrm{N}_{\mathrm{l}}\right)$

Cyclic Stress Ratio versus Shear Wave Velocity

Shear Wave Velocity versus Maximum Acceleration

Figure 7-7

Figure 7-8

Charleston Earthquake: Liquefaction / Marginal Liquefaction Data

Figure 7-9

Figure 7-10

Figure 7-11

Figure 7-12

Figure 7-13

Figure 7-14

Figure 7-15

Charleston Earthquake: No Liquefaction / Marginal Liquefaction Data

Influence of Period of Sustained Pressure on Stress Ratio Causing 100\% Pore

Pressure

Figure 7-16

Figure 7-17

Influence of Age on Relative Strength Against Liquefaction

Cyclic Stress Ratio versus Cone Penetration Tip Resistance

Volumetric Strain versus Factor of Safety

Pore Pressure Ratio versus Shear Strain

Load / Settlement versus Time

ITP "Soft Zone" Subsurface Profile A - A'

ITP "Soft Zone" Subsurface Profile B - B'

ITP Worst Case Settlement Profile 


\section{Disclaimer}

This report was prepared as an account of work sponsored by an agency of the United States Government. Neither the United States Government nor any agency thereof, nor any of their employees, makes any warranty, express or implied, or assumes any legal liability or responsibility for the accuracy, completeness, or usefulness of any information, apparatus, product, or process disclosed, or represents that its use would not infringe privately owned rights. Reference herein to any specific commercial product, or process or service by the trade name, trademark, manufacturer, or otherwise, does not necessarily constitute or imply its endorsement, recommendation, or favoring by the United States. Government or any agency thereof. The views and opinions of authors expressed herein do not necessarily state or reflect those of the United States Government or any agency thereof. 


\subsection{INTRODUCTION}

A geotechnical investigation has been completed for the In Tank Processing Facility (TTP) which consists of buildings $241-96 \mathrm{H}$ and $241-32 \mathrm{H}$; and Tanks $241-948 \mathrm{H}, 241-949 \mathrm{H}, 241-950 \mathrm{H}$, and 241-951H. The investigation consisted of a literature search for relevant technical data, field explorations, field and laboratory testing, and analyses. This document presents a summary of the scope and results to date of the investigations and engineering analyses for these facilities. A final geotechnical report, which will include a more detailed discussion and all associated boring logs, laboratory test results, and analyses will be issued in October 1994.

The purpose of the investigation is to obtain geotechnical information to evaluate the seismic performance of the foundation materials and embankments under and around the ITP. The geotechnical engineering objectives of the investigation are to: 1) define the subsurface stratigraphy, 2) obtain representative engineering properties of the subsurface materials, 3) assess the competence of the subsurface materials under static and dynamic loads, 4) deriye properties for seismic soil-structure interaction analysis, 5) evaluate the areal and vertical extent of horizons that might cause dynamic settlement or instability, and 6) determine settlement at the foundation level of the tanks. To this end, four major areas of studies and analyses are required:

- Seismology and geology

$+$

- Seismic stability and deformation of slopes

- Liquefaction susceptibility and settlement

- Deep-seated settlement

A summary of the results for the above areas of analyses is given in the sections that follow.

\subsection{Previous Investigations}

Several reports and studies have been completed for the ITP and the H-Tank Farm. A detailed synopsis of these studies can be found in the Program Plan (HLW-ENG-930017). For the ITP, three separate reports were prepared (Mueser et al., 1977, 1978, and 1984a).

\subsection{1 'High Level Waste Storage Tanks Nos. 48 through 51 (Raymond International Inc., 1976; Mueser et al., 1977)"}

The initial phase of this investigation included drilling of fifteen borings extending to depths of between 80 and 195.3 feet and installation of one piezometer to a depth of 45.5 feet. Standard penetration tests (SPT) were performed and undisturbed sampling obtained. Laboratory tests on recovered undisturbed samples disclosed the existence of a deep layer of compressible clay. This clay was encountered near the northern half of the then-proposed location of Tank 51 (located to the east of existing Tank 49). 


\subsection{2. 'New High Level Waste Storage Tanks Nos. 50 and 51 (Mueser et al., 1978)"}

Five additional borings were drilled within the footprint of Tanks 48 and 51. Rod drops, fluid loss, and high grout takes were recorded in three of the borings. Settlement predictions under static loading included: two inches total for Tanks 48, 49, and 50; and two inches differential for Tank 51.

\subsection{3 "In-Tank Precipitation Facility (Mueser et al., 1984a)"}

Five borings, extending to depths of 201.5 feet, were drilled near the southeastern toe of the embankment. Results of the field density tests performed on the embankment fill were reviewed for areas surrounding the Filter Enclosure Building. It was reported that approximately half of the measurements in the lower five feet of the original embankment fill were compacted to less than 95\% of the specified modified proctor dry density. No adverse conditions (soft zones, fluid loss, soft pockets) were noted in the native subsurface soils, however, except for the-presence of calcareous material in the deep boreholes.

\subsection{SEISMOLOGY AND GEOLOGY}

Following the ITP Program Plan, the seismology investigation consisted of reviewing the KReactor spectra (hereafter referred to as the Evaluation Basis Earthquake, EBE, spectra (Figure 2-1) for applicability to the ITP facility. As part of this review, ITP specific properties were considered. Based on the findings discussed below, the EBE spectra were recommended for the geotechnical investigation as opposed to the enveloping Blume response spectrum (see Figure 21). The EBE spectra establish more representative ground motions for the geotechnical . evaluation.

Deterministic median and 84th percentile rock spectra were developed to compare to the estimated K-Reactor distant event EBE rock spectrum. The derived median and 84th percentile ITP rock spectra are respectively referred to as the ITP miedian rock and ITP 84th rock spectrum.

\subsection{Summary of Parameters Associated with the Development of the EBE Soil Spectra}

The EBE distant soil spectrum was previously derived by Random Vibration Theory modeling of the source and path in combination with SHAKE (Schnabel et al., 1972) or equivalent analysis as described in the sections to follow.

The source distance used to develop the EBE soil spectrum is considered greater than median. The other properties are considered to be median values, which include region specific elastic and anelastic properties, Kappa, and site specific soil properties. Using these parameters results in an EBE rock and soil spectrum being greater than a median.

The following sections outline the parameters used in generating the distant EBE spectrum. 


\subsubsection{Source Parameters}

A Mw 7.5 earthquake at a distant of 120 kilometers $(\mathrm{km})$ with a stress drop of 150 bars was used to derive a rock response spectral shape. This shape was scaled to a higher peak ground acceleration (PGA) corresponding to a source distance of $110 \mathrm{~km}$. The magnitude and stressdrop source parameters are above or in the upper range of values considered median for a repeat of the 1886 Charleston earthquake. The source distance of $110-120 \mathrm{~km}$ is considerably closer than the $145 \mathrm{~km}$ distance of the 1886 epicenter.

\subsubsection{Structure Q}

A Coastal Plain specific Q model and crustal structure were used to model ground motions, and they are considered median models.

\subsubsection{Kappa Bedrock}

The Kappa (bedrock attenuation factor) value used is median based on ranges déveloped in the literature. There are no site specific data available to provide constraints on Kappa. Bedrock Pwave velocity is constrained by basement refraction velocities. Basement $S$-waye speeds are developed using a Poisson solid relationship. The geometry of the Triassic basin is constrained by seismic reflection data and a.1-D model approximation is used to determine ground motion effects of the basin. The model suggests that the presence of the basin in the K-Reactor ground motion model does not significantly alter the spectra with respect to its application for the ITP.

\subsubsection{Soil model}

Ground motion models are compared using soil models for the K-Reactor and the ITP. The ITP model uses an average of ITP shallow S-wave velocity (Vs) coupled with a deeper Vs profile measured at the Pen Branch Fault Confirmatory Drilling Site. The deep Vs profile is significantly faster than the assumed profile originally used for K-Area. However, comparisons of shallow (less than 200 feet) dynamic properties indicate that K-Reactor is a stiffer site with less damping than the ITP site. A lower surface response is predicted at ITP as compared to the K-Reactor when the same bedrock motion is used at both facilities.

\subsection{ITP Median and 84th Percentile Rock Motions}

Preliminary median and 84th percentile rock spectra for the ITP are shown in Figure 2-2. The distant.controlling median spectrum represent a Mw 7.5 earthquake at a distance of $145 \mathrm{~km}$ combined with a stress drop of 150 bars. The 84th percentile rock motions are derived by using the recently developed EPRI frequency dependent standard error (Toro et al., 1994).

Rock spectrum for K-Reactor is not available from the Geomatrix (1991) work, consequently, an approximation to that spectrum is developed. Figure 2-2 compares the RVT rock motions using Geomatrix. (1991) source parameters (i.e., Mw 7.5, stress drop 150 bars, and distance of $120 \mathrm{~km}$ ) versus the ITP median and 84 th percentile rock motions. 
Using ITP site specific properties, median motions for a repeat of the 1886 Charleston earthquake are derived which produce significantly less rock motion than the EBE rock spectrum, which again indicates that the EBE spectrum is greater than the median. The 84th percentile spectrum, derived from the ITP median site spectrum and conservative frequency dependent scaling parameters for US mid-continent crustal structure, is in excess of the EBE rock spectrum.

\subsection{Summary}

Deterministic distant event rock spectrum using subsurface data was developed for the 50th and 84th percentile expected rock motions for ITP. The results indicate that the controlling distant event rock spectrum (EBE) falls between the 50th and the 84th percentile of predicted deterministic motions. The contribution to risk of the EBE soil response spectra and the 84th percentile distant response spectrum will be evaluated in the probabilistic analysis, scheduled for completion in December, 1994. Based on available data, application of the K-Reaetor spectra (EBE) at the ITP facility provides at least the same degree of conservatism in ground motion during an earthquake as was developed for K-Reactor. Consequently, the EBE controlling spectra are judged acceptable for the ITP deterministic geotechnical evaluation.

\subsection{Introduction to Calcareous Sequences Beneath the GSA}

The lithostratigraphic sequence at the General Separations Area (GSA), which includes F-Area; H-Area, and the Burial Ground, is composed mostly of terrigenous clastics interspersed with carbonate-rich clastics and limestones. The clastic facies consist of gravel and/or pebble sands, . clayey sands, silt, clay, and sandy clay. The calcareous facies consist of calcareous sand, calcareous mud, limestone, sandy limestone, and sandy and muddy limestone. The terrigenous clastic lithofacies are dominant throughout the GSA and occur within all hydrostratigraphic units. Approximately $45 \%$ of all wells drilled in the GSA that penetrated the Dry Branch-Santee interval have intersected appreciable amounts of carbonate. The distribution of drill holes, however, is highly clustered making trend delineation highly speculative. The chronology of geological everits showing the depositional history in the vicinity of the H-Area Tank Farm is presented in Table 21.

\subsection{Carbonate Stratigraphy}

The calcareous lithofacies in the GSA region is discontinuous, but confined to three distinct stratigraphic horizons of different ages and depositional setting. The lower horizon (Santee Formation) has been identified in three separate areas in the GSA possibly along a northeastsouthwest trend (Figure 2-3). Continued drilling has located comparable carbonate bodies throughout the GSA (e.g. at the H Area Tank Farm):

1. The lower horizon is the Santee Limestone within the Tinker Formation. This horizon thickens and thins rapidly. Faulting observed on the various cross-sections that transect the GSA typically occurs within or on the flanks of these carbonate zones. 
2. The middle carbonate horizon is the Utley (?) Limestone Member of the Clinchfield Formation.

3. The upper carbonate horizon is the Griffins Landing Member of the Dry Branch Formation. The Griffins Landing Member is younger than the Utley and occurs on top of the Utley when both members are present. Due to the discontinuous nature of the middle and upper carbonate horizons, it can be especially difficult to distinguish between them from the core descriptions thus making stratigraphic correlation a difficult problem (e.g. at the H Area Tank Farm). Correlation in these zones requires careful examination and interpretation of both core, paleontological and geophysical data.

A comparison of the stratigraphic nomenclature used on the cone penetrometer logs with the stratigraphic nomenclature used for the geologic maps and cross-sections is shown on Figure 2-4.

\subsection{Carbonate Lithologies}

In the GSA region, carbonate-rich clastics and limestone in the three carbonate horizons in the Santee-Dry Branch stratigraphic interval varies widely. Calcareous sands range in thickness from 2 to 33 feet. Sandy and muddy limestones and limestones range in thickness from 3 to 30 feet. Figure 2-3 illustrates the thickness of the three calcareous carbonate horizons in the GSA area.

The calcareous sands are white to buff in color and contain up to 50 percent calcareous materials, Shell fragments (gastropods, pelecypods, echinoderms, bryozoans, and barnacles) and whole foraminifera are common in the sands. The sand is quartz rich and is generally fine grained, subangular, and well to moderately sorted. Small percentages of glauconite are common.

The sandy and muddy limestones and limestones are white to buff in color and contain greater than 80 percent calcareous material. Glauconite is common in this unit. Many of the limestones are partially to fully consolidated with abundant moldic porosity from fossil molds. Shells are dominantly pelecypods and gastropods. Unconsolidated limestones are generally a "coquina" type shell hash consisting of shell fragments of pelecypods, gastropods, echinoderms, bryozoans, and barnacles. Thin silicified layers of this shell hash $(<0.5$ feet) are occasionally observed in this unit.

Modern analogues of the fossiliferous limestones are the elongate (parallel to the shoreline) "shell hash" mounds that typify the Chandaleur Islands off the Mississippi delta of Louisiana, and the shallow marine shelf bioherms, which commonly contain some percentage of fine-grained sands and mud, observed in the Florida Bay near the Keys. At the Florida Bay, the shell mounds are commonly observed surrounded by the silty, clayey, often shell-bearing sands of the shallow shelf. The result is a sedimentary sequence with an initial non-uniform distribution of carbonate-bearing to carbonate-rich debris. From the data currently available, the carbonate buildups in the GSA appear to be oriented northeast-southwest, paralleling the strike of the shoreline at that time. Figure 2-5 shows a map of a modern analog of these shell bank shoals and adjacent deeper basins. For comparison, the inferred configuration of the carbonate bodies within the GSA Area based on currently available data is shown in Figure 2-3. 


\section{7 "Loose Zones" in the GSA Area}

Weight of rod and occasional rod drop have been described in numerous drilling reports for wells drilled in the GSA. These soft zones typically occur in the carbonate-rich sediments in the Santee Limestone, Utley Limestone, and the lower portions of the Dry Branch Formation. The prevailing assumption of the causal mechanism for the soft zones has historically been dissolution of the carbonate-rich sediments in the zone resulting in vugular porosity where the rod meets little or no resistance. An alternative hypothesis for the cause of the "soft zone" phenomenon is that the drill rod was pushed into uncemented sands that may have been in a "pressure shadow" (under ambient hydrostatic pressure) due to the support of the overburden by the overlying indurated beds.

Silica cementation of the sand and clayey sand sequences and the localized zones of calcareous sand, sandy and muddy limestones, and limestones is common in the Santee Formation and overlying lower Dry Branch Formation. Silica cementation varies from a trace to more than $30 \%$ of the sediment analyzed, and individual hard cemented layers can vary from less than 1 - foot to more than 10 feet in thickness. The silica cementation occurs in the various lithofacies found in the two formations.

During recent drilling activity in the GSA, soft zones were recorded immediately after drilling through a well-cemented siliceous bed or beds. Indeed, "soft zones" have been commonly shown to have occurred immediately after drilling through a hard well-cemented siliceous bed or beds irrespective of the specific lithology of the parent material.

For example, well OFS-2 SB, recently drilled just south of the Burial Grounds in the GSA, recorded 20 feet (from a depth of 100 feet to 120 feet) of variably silica-cemented micritic sands. The lithology at the same stratigraphic interval in nearby wells is commonly biomoldic micritic sand. From a depth of 100 feet to 109 feet the sands become increasingly well-cemented and reach a lithification level of 3 (must be cleaved with difficulty with a spatula), on a scale of 1 (like soup) to 4 (rock-like). The depth from 109 feet to 110 feet was a no recovery zone, and from 110 feet to 112 feet medium- to fine-grained sand with an induration level of 1 (like soup) was recovered. From 112 feet to 120 feet well-cemented micritic sands were recorded again reaching an induration level 3.

This suggests the soft zones are discontinuous and the alternative hypothesis for the cause of the "soft zone" phenomenon, namely that the drill rod was pushed into uncemented sands that may have been in a "pressure shadow" (under ambient hydrostatic pressure) due to the support of the overburden by the overlying indurated beds. In this case the toose sands would behave like a mixture of water and sand where grain to grain support is minimal. The drill rods drop through the loose sand zone because the load bearing strength is greatly reduced.

This hypothesis is further supported by the core data and field information from boring BGX-4a as illustrated in Figure 2-6. Here calcareous sands and sandy, shelly micrite (carbonate mud) was penetrated from depths of 140 feet to 151 feet with an increasing degree of cementation and induration encountered. At 151 feet, slightly indurated fine-grained well-sorted sand was encountered before an 8-foot soft zone occurred. Renewed core recovery occurred only when 
slightly indurated sandy clay to clayey sand was encountered. The interval where the soft zone occurred probably contained loose fine-grained, well-sorted sand first encountered below 151 feet. Again there is the suggestion that the drill rod was pushed into uncemented sands that may have been in a "pressure shadow" created by the overlying indurated competent beds.

Soft zones associated with well-cemented, silicified units (hard grounds) have been 'noted in clastic lithofacies where carbonate percentages are low, but generally present. Thus, the phenomenon is not restricted to obvious well-delineated carbonate terranes. The silica-cemented horizons are commonly noted at or near the top of the Santee in the GSA, both in carbonatebearing clastic and limestones lithofacies, at or near the unconformity that separates the Santee from the overlying Dry Branch Formation. The cemented horizon appears similar to the cemented zones associated with rapid lateral and vertical movement of fresh to saline ground water at the water table in modern coastal environments, where rapid cementation and decementation can occur (thus explaining the hard ground and the underlying "soft zones"). Irrespective of the details, the process is associated with proximity to the water table:- Thus, the hard grounds and underlying "soft zones" probably developed in the time frame of the unconformity at the end of Santee time about 40-43 million years before present (mybp). At the present time, the top of the Santee in the GSA, approximately 150 feet below ground surface, is well below the water table. For much if not most of the period since the end of Santee deposition, the above described diagenetic alteration to both the carbonate and clastic sediments has in all likelihood been negligible.

\subsection{Faulting Associated With Carbonate Buildups}

For the purposes of this discussion, faults are defined in a geological context, as any offset or displacement of sediments by any mechanism. Therefore, displacement of sediments due to deepseated crustal movements, or due to differential compaction due to dewatering in the soil horizon for example, would be considered faults.

Siple (1967) speculated that dissolution of calcareous material in the Santee Limestone has occurred at the SRS and caused subsidence of overlying beds along slump faults and the formation of surface depressions. He noted that voids and loosely compacted sediments were encountered during well drilling and mentioned that large amounts of cement grout were used to stabilize the subsurface before construction of heavy structures. This speculation may not represent a complete understanding of all the processes at work.

Faults are commonly observed in the GSA along the flanks-of the carbonate buildups. The relationship between the shallow faults noted at the GSA and the distribution of carbonate in the Santee, Utley, and Dry Branch formations have two possible mechanisms for their formation. The first alternative suggests that faulting of the section occurred, due to slumping of the sediments above the carbonate buildups where differential dissolution of the carbonate interval occurred. Here, thinning of the interval where the carbonate was removed occurred due to compaction of the remaining sediment. The second alternative explanation is due to preferential dissolution of carbonate associated with existing faults, without necessarily compacting the interval where carbonate was dissolved. Here the fault plane, already in existence, acted as a conduit for the 
movement of the ground water responsible for the dissolution of the flanking carbonate. Both alternatives appear reasonable at this time in the area of the H-Area Tank Farm (Figure 2-7). Figure 2-8 is a map of the ITP area showing elevations of the top of the Tobacco Road Formation compared to the currently known distribution of limestone. Note the interpreted fault lines flanking the carbonate.

It is significant that the Tinker Formation in the central portion of Figure 2-7 appears to have been unaffected by the process that displaced the overlying units. This suggests that the displacement of the overlying units is the result of dissolution of the carbonate materials within the Dry Branch Formation and not due to offset on basement faults. Therefore it will be very important to establish the stratigraphic position and distribution of all carbonate horizons within the GSA.

The offset of the units between cone penetrometer sites CPT 23 and CPT 11 shown on Figure 2-7 may involve Tinker and the underlying units. This suggests offset due to deep-seated faulting rather than due to dissolution of carbonate. Consequently, both faulting mechanismis described earlier appears to have occurred. Future work will be required to confirm these mechanisms.

The currently available data indicate an internal continuity and an absence of disruption of bed form within the units above the carbonate bearing zones in the vicinity of the offsets. This suggests that the displacement due to carbonate dissolution was a gradual slow subsidence rather than a sudden movement. Sudden dramatic collapse should have induced more of a disruption of the bed forms if sudden dramatic collapse occurred.

\subsection{SUBSURFACE EXPLORATION}

Subsurface information in the ITP area is available from pre-construction borings performed for the initial tank foundation investigations, as well as, from three recently completed exploratory phases. Each phase is summarized as follows:

\subsection{Phase 1 (December 1992 to April 1993)}

A series of Standard Penetration Test borings (SPT) and Seismic Piezocone Penetration Test soundings (herein referred to as CPT) were performed around the facility for the purposes of developing a preliminary subsurface characterization, and performing a preliminary engineering analysis. SPT borings and CPT probes were paired such that a site specific comparison of results, using paired data sets, could be determined. This allowed the CPT to be utilized as the primary exploration tool in areas where soil extraction by sampling was not practical. SPT sampling was performed continuously driving an 18-inch split spoon sampler to a depth of approximately 185 feet. Soil samples collected from SPT borings were tested for classification purposes. Four Flat Plate Dilatometer (DMT) soundings, located near the borings and CPT probe locations, and grout injection tests in two suspect areas were also performed in Phase 1. 


\subsection{Phase 2 (April 1993 to November 1993)}

Phase 2 was initiated to investigate areas of potential concern identified in Phase 1 investigation, as well as to collect information to support a detailed engineering analysis. Exploratory techniques consisted of collecting high quality undisturbed soil samples for laboratory testing, cross-hole shear wave velocity surveys to confirm down-hole techniques, core sampling of the grout injection test area, geophysical surveys to supplement the geologic characterization, and additional CPT probes.

\subsection{Phase 3 (November 1993 to Present)}

The objectives of the work under this phase were to obtain additional information about the structural embankment fill and the "soft" zones within the lower Dry Branch and upper Santee Formations; and the characterization of potential offsets and confirmation of the western boundary of the carbonate deposit. Investigative techniques used included: surface seismic surveys, soil coring and down-hole geophysical logging, undisturbed sampling of target "soft zones" and of the structural embankment fill, and one SPT boring.

In summary, the to-date preconstruction and combined Phase 1 through 3 explorations for the ITP area can be summarized as follows:
20-CPTs
4-DMTs
5-SPTs
6-Undisturbed Sample borings
2-Undisturbed Core borings
8-Core borings
5-Cross hole straight drill holes
34-Pre-construction soil borings
3-Cross-hole surveys
1-Down-hole Refraction Survey, consisting of 3 separate lines
1-Shallow High Resolution Seismic Reflection Survey, consisting of 4 separate lines
1-Grout Injection Test at two locations

Figure 3-1 shows the boring locations for the preconstruction and Phase 1 through 3 explorations.

Remaining field work to be completed under the H-Area Tank Farm program includes:

1-High resolution seismic reflection survey ( 5 miles of line)

2-Shallow core borings

3-SPTs

13-CPTs

1-Tomography survey consisting of approximately 10 panels near Tank 51

The above field work is currently scheduled to be completed by early 1995 . 


\subsection{LABORATORY TESTING}

Laboratory testing was performed on representative samples of the subsurface materials, using ASTM standards and others, as appropriate. The samples were collected and tested according to the quality assurance/control requirements outlined in WSRC IQ manual.

Laboratory testing consisted of Atterberg limits, gradation, hydrometer, specific gravity, X-ray diffraction, static and dynamic strength, consolidation, threshold strain determination, post-cyclic strength, dynamic properties (modulus and damping), and post-cyclic volumetric strain determination. Table 4-1 lists (with the exception of classification and index tests) the number and types of test performed for each subsurface stratum. The results of these tests, tests from other areas at SRS, and field performance data were utilized to determine representative soil properties as given in Section 6.0.

In general, the selection of samples for laboratory testing was done based on the soil classification from the field boring logs and on the preliminary subsurface profile developed as part of the Phase 1 exploration (Bechtel Savannah River Inc., 1993). Re-assignment of testing was made, as necessary, based on observations made in the laboratory.

All laboratory testing was performed by Law Engineering and Testing Company in Atlanta, Georgia with the exception of the stress-controlled cyclic triaxial, threshold strain, post cyclic strength, and X-ray diffraction tests. These latter tests were performed by the University of California-Berkeley under contract to Law Engineering.

\subsection{SUBSURFACE CONDITIONS AT THE ITP}

The subsurface conditions were determined based on the field exploration described in Section 3.0 and previous information described in Section 1.0. Two representative profiles were developed as shown in Figures 5-1 and 5-2. Each soil stratum is described below.

\subsection{Tobacco Road Formation}

The Tobacco Road Formation consists predominately of clayey sand (SC) and silty sand (SM) with interbeds of poorly graded sand (SP), silty sand (SP-SM), and clay (CH). Kaolinite is the predominate clay mineral in the Tobacco Road (Law, 1994). For this investigation, the soils in the Tobacco Road Formation (TR) were considered to be stratified into 4 layers: TR1, TR2, TR3, and TR4. However, the upper layers, TR1 and TR2 may actually be part of the Upland unit (Altamaha equivalent), which is shown as the surficial unit in H-Area by the U.S.G.S. (U.S.G.S. Open-File Report 94-181, Plate 1).

Typically; TR1 is a reddish brown to purple, clayey sand (SC) with interbeds of mottled purple and brown clay $(\mathrm{CH})$ and clayey sand that are prevalent near the base of the layer. The underlying TR2 layer is a dense, purple to red silty sand (SM) with interbeds of poorly graded sand (SP, SPSM), and some silt (SM). Because of conspicuous changes in the thickness of TR2, it appears 
that TR1 lies unconformably on TR2 and has eroded or cut TR2 at ITP. At the base of TR2, a pronounced decrease in the CPT tip resistance and an increase in the pore-pressure signature marks the contact with the underlying TR3 layer.

The sand in TR3 is less dense and more clayey than that of TR2. TR3 consists of mottled red, brown, tan, and white clayey sand with some interbeds of clayey silty sand (SC, SC-SM). TR4 is similar to TR3, but is distinguished by a moderate increase in CPT tip resistance [40 to 50 tons per square foot (tsf) increase] and a slight decrease in CPT friction ratio and pore pressure generation. TR4 is comprised of red, purple, or white poorly graded sands and silty sands (SPSM, SM).

\subsection{Dry Branch Formation}

Layers DB1 through DB3 encompass the Irwinton Sand Member of the Dry Branch Formation. DB1 and DB3 are dense, brown, poorly graded sand with some silt (SP-SM). DB2 is a 5 to 10foot-thick layer of silty sand and clayey sand (SC) which generates excess CPT pore pressures and is traceable across the ITP area.

Layers DB4 and DB5 of the Dry Branch Formation probably comprise the Tan Clay and Griffins Landing Members of the Dry Branch Formation, respectively. Depositionally, the DB4/DB5 interval is complex. The soils range from highly plastic clays (CH) to clayey sands (SC) to silty sands and sandy silts (SM and ML). In general; DB4 consists of non-calcareous to slightly calcareous, alternating layers of brown, tan, and white, clayey sands (SC) and clays (CH). DB5 is generally more silty and is calcareous in some places. DB5 is often described as a light olive green to gray sandy silt (ML) and silty sand (SM) with varying amounts of clay (CH) and shell fragments. Both DB4 and DB5 can become moderately to highly plastic at some locales. X-ray diffraction tests show that smectite is the predominant clay mineral in the lower Dry Branch Formation (Law, 1994).

\subsection{Santee Formation}

The contact between the Dry Branch and the Santee Formations is difficult to distinguish. The sharp decrease in the excess pore pressure signature on the CPT logs was selected to define the boundary between these formations. This demarcation is easily seen on the CPT logs, but may not necessarily represent the formational contact.

The Santee Formation (ST) at the ITP is depositionally complex and highly variable in its lithology. Three facies appear in the upper Santee Formation in the vicinity of the ITP tanks: (1) a moldic limestone facies, (2) a sandy/silty facies with varying amounts of shell fragments and carbonate sands, and (3) a slightly calcareous to non-calcareous, silty to clay sandy facies. The limestone facies predominates on the eastern side of ITP (Figure 5-3). To the west and north, these calcareous sediments transition to predominately non-calcareous clayey and silty sands. In this transition zone, silty sands, sandy silts, and carbonate sands with shell fragments are interfingered with the moldic limestone and non-calcareous clayey sands. Characteristically, CPT soundings in the upper Santee Formation show a pronounced "saw tooth" trace due to/large 
changes in CPT tip resistances. This pattern suggests interfingering of thin layers of sands and clayey sands with varying amounts of carbonate cementation and/or shell hash. The saw tooth pattern has probably been accentuated by post-depositional diagenetic changes such as preferential cementation and/or dissolutioning (Section 2.7).

\subsection{Soft Zones in the Dry Branch and Santee Formations at the ITP}

The Tan Clay/Griffins Landing Members of the Dry Branch Formation and a sandy/silty facies with shell fragments and carbonate sands found within the Santee Formation show at times low SPT N-values and CPT tip resistances. For a general discussion of the soft zones in the H-Tank Farm Area, refer to Section 2.7. This section discusses those conditions found specifically at the ITP.

For the most part, the low penetration resistances in the Dry Branch Formation occur in a highly plastic clay $(\mathrm{CH})$, which is on average, normally consolidated. During previouș subsurface investigations at the ITP in (Mueser et al., 1977 and 1978), this compressible clay layer was found at an approximate depth of 120 feet below ground surface and was located about iö feet east of the present location of Tank 49. (Note the cluster of preconstruction borings in Figure 3-1 at this location.) Because of concerns about the potentially high differential tank settlements at the proposed 1977 site for Tank 51, Mueser et al. recommended that the 1977 tank layout be revised, resulting in the present tank layout at ITP. This compressible clay layer does not extend in any significant thickness underneath the present tank layout, and hence poses no significant threat of differential settlement to the tanks. This has been confirmed by actual tank settlement readings obtained after construction, which will be discussed later.

The location and thickness of the soft zones in the Santee Formation were identified using the CPT and SPT logs for all intervals meeting the following criteria: (1) CPT tip resistances $<15$ tsf or (2) SPT blow count $<5$. Based on these data, it appears that the soft zones are concentrated in two horizons which dip approximately 5 percent to the west. Because this dip parallels that of the overlying strata, it appears that the soft zones in the Santee Formation are not random, but are depositionally controlled. In the vicinity of the ITP tanks, the upper soft zone horizon has a thickness of approximately 10 feet and occurs between elevations 170 and 160 feet MSL. The lower horizon is generally much thinner and less continuous. It has a maximum thickness of 5 feet in the vicinity of Tank 51 and occurs between elevations 138 and 133 feet MSL.

The soft zones in the Santee Formation parallel the moldic limestone in a broad band that is approximately 200 feet wide (see Facies 2 in Figure 5-3). However, it is unlikely that any given individual pocket or stringer of soft material is laterally continuous over that distance. Poor lateral correlation of SPT and CPT penetration resistances, even for closely spaced boreholes, suggests large heterogeneity over short horizontal distances. Based on these-data, no lateral continuity appears to exist over horizontal distances that are greater than a few tens of feet. 


\subsection{ENGINEERING PROPERTIES}

Table 6-1 is a summary of the mean engineering properties for the layers described in Section 5.1. All of these data, except for some of the compressibility data, were collected as part of the activities described in HLW-ENG-930017. The compressibility data (i.e., overconsolidation ratio, compression index, re-compression index, and coefficient of consolidation) contain measurements made under this program and that of Mueser et al., 1977, 1978, and 1984.

Downhole and crosshole shear wave velocity measurements near the ITP tanks show that the soil profile is moderately stiff, on average (Ebasco, 1994a, 1994b). Crosshole shear wave velocities generally range from about 1000 to 1275 feet per second (fps) (Ebasco, 1994b). Downhole shear wave velocities generally range between 950 to $1250 \mathrm{fps}$ for the profile and show good agreement with the crosshole measurements. Figure 6-1 presents a summary of the downhole shear wave velocity measurements.

\subsection{ENGINEERING ANALYSES}

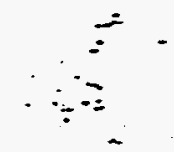

\subsection{Evaluation of Slope Stability}

The stability of the slopes surrounding Tanks 48-51 was evaluated using limit equilibrium analysis for static and pseudo-static conditions. Circular and wedge-shaped failure surfaces were considered. Circular surfaces were analyzed using the Modified Bishop Method and wedgeshaped surfaces were analyzed using Janbu's Method. Seismic conditions were simulated by applying horizontal and vertical inertial forces corresponding to selected levels of ground accelerations.

The slope was modeled so as to reflect the three typical cases that represent the various geometries and loading configurations present. The slope geometry was obtained by five field surveys. For this summary report only cross-section 1 is reported (Figure 7-1). Cross-section 1 is typical of the west slope at the Filter Building and includes a 2700 psf surcharge load from the building. This section produces the lowest safety factors computed.

The slope is composed of approximately $\mathbf{4 0}$ feet of fill. A review of construction data indicated a thin zone (approximately 2 feet thick) of soft material located at the base of the fill as noted previously by Mueser et al., (1984a). This was confirmed by 6 of the 7 CPT soundings located along the edge of the slope. This material is identified as Filt 2 in Figure 7-1. The overlying material was considered to act as a single unit (Fill 1).

Static (long term) conditions were evaluated using effective stress strength parameters. Pseudostatic (short term) conditions were evaluated using total stress strength parameters. Strength parameters were developed as a result of evaluation of field and laboratory test data. The properties used (Table 7-1) represent "best estimate" properties based on mean values. 


\subsubsection{Static Factors of Safety}

The static (long term) factor of safety was evaluated utilizing effective stress shear strength parameters. The minimum computed factor of safety is 1.9 , which exceeds the 1.5 factor of safety required by the program plan (HLW-ENG-930017). The critical failure surface is a toe circle as shown on Figure 7-1.

\subsubsection{Pseudo-Static (Short Term) Analysis}

For the pseudo-static analysis, a horizontal acceleration of $0.2 \mathrm{~g}$ was utilized. A vertical acceleration of $0.08 \mathrm{~g}$, which is equivalent to 40 percent of the horizontal acceleration, was also incorporated in the analysis. The fill shear strength was reduced by $10 \%$ to account for seismic straining. The resulting factor of safety for cross-section 1 is 1.7 (Figure 7-1) for the critical failure surface which is wedge-shaped.

Earthquake-induced slope deformations were estimated following the method. Makdisi and Seed (1977). For this estimate, the maximum slope acceleration $\left(A_{m}\right)$ was determined from the SASSI analysis (Section 7.4.2) to be conservatively $0.2 \mathrm{~g}$. For the critical failure surface, the yield acceleration $\left(A_{y}\right)$, i.e., the acceleration that results in a safety factor of one, is calculated to be $0.6 \mathrm{~g}$. The ratio of yield acceleration to maximum slope acceleration $\left(A_{y} / A_{m}\right)$ is approximately 3. As determined by Makdisi and Seed (1977), a $A_{y} / A_{m}$ ratio $>1$ will result in negligible deformation of the slope (Figure 7-2).

\subsection{Liquefaction Susceptibility}

The liquefaction susceptibility of the subsurface materials at the ITP site was evaluated using both qualitative and quantitative approaches. For this, an extensive field and laboratory program was conducted to characterize the site conditions and to measure the cyclic shear strength and deformation characteristics of the materials. In this section, a summary of the liquefaction evaluation is presented.

\subsubsection{Criteria for Clayey Soils}

Both laboratory tests and field performance data have shown that the great majority of clayey soils will not liquefy during earthquakes. Criteria to express these observations have been formulated by Wang (1979) and extended to the laboratory testing conditions in the United States by Koester and Franklin (1985). The extended criteria state that clayey soils must satisfy all of the three following conditions to be judged vulnerable to liquefaction or serious loss of strength:

1. Laboratory-determined water content (increased by two percent) greater than 90 percent of the laboratory-determined liquid limit (increased by one percent);

2. Liquid limit (increased by one percent) is less than 35 percent, and

3. Clay content (decreased by five percent) is less than 15 percent. 
Test data for ITP soils are summarized and plotted in Figures 7-3a through 7-3e. By inspection the application of the criteria to the individual samples for which complete data are available show that the vulnerability of the clayey sands to seismic liquefaction is negligible at ITP.

\subsubsection{Shear Wave Velocity Approach}

Attempts to relate shear wave velocity to liquefaction susceptibility using empirical data have been pursued by several investigators. For example, Seed, Idriss, and Arango (1983) concluded that: "Liquefaction will never occur in any earthquake if the shear wave velocity in the upper 50 feet of soil exceeds about 1200 fps" (see Figure 7-4). This conclusion was based on the consideration of the cyclic shear stresses.(and corresponding shear moduli) required to induce liquefaction in the field, according to empirical field data.

Similarly, Kayen et al. (1992) and Stokoe et al. (1988) compiled field data obtained in recent earthquakes which show relationships between cyclic stress ratio and normalized shear wave velocity, and between shear wave velocity and maximum ground surface acceleration, respectively. These relationships separate sands into groups which are susceptible or nonsusceptible to liquefaction (Figures 7-5 and 7-6).

The geophysical survey carried out at the ITP yield the average and normalized shear wave velocity values for the various soil layers given in Table 7-2. Based on this data and with reference to Figures $7-4$ through $7-6$, the following is concluded:

1. Seed et al.'s chart (Figure 7-4) indicates that materials between depths of $50-100$ feet with an average shear wave velocity equal to about $1100 \mathrm{ft} / \mathrm{sec}$ would have a cyclic stress ratio resistance against liquefaction of 0.28 . Maximum expected cyclic stress ratios at the site in the event of the EBE are less than 0.15 , which is well below 0.28 . Thus, the liquefaction potential at this site is nonexistent.

2. The normalized shear wave velocities presented in Table 7-2 used in combination with Kayen et al's chart (Figure 7-5) show that Tobacco Road soils (TR1 through TR4) with normalized velocities between $250 \mathrm{~m} / \mathrm{sec}$ and $270 \mathrm{~m} / \mathrm{sec}$ would require a cyclic stress ratio in excess of 0.40 to liquefy. Dry Branch soils (DB1 through DB5) with the lowest normalized shear wave velocities of about $200 \mathrm{~m} / \mathrm{sec}$ would require cyclic stress ratios which are much greater than the cyclic ratio expected to be generated by the EBE to liquefy. Therefore, no liquefaction is predicted by this method.

3. Stokoe et al.'s chart (Figure 7-6) would show that for shear wave velocities greater than 500 $\mathrm{ft} / \mathrm{sec}$, the required ground acceleration that causes liquefaction is $0.25 \mathrm{~g}$. At the ITP site, shear wave velocities are twice this value, and expected peak ground acceleration $(0.19 \mathrm{~g})$ is lower than the quoted value. Therefore, this criterion precludes liquefaction at the site.

In conclusion, based on the observations made by Seed, Idriss, and Arango (1983), Kayen et al. (1992), and Stokoe et al. (1988) liquefaction at the ITP site will not occur during the EBE. 


\subsubsection{Performance of Old Sand Deposits}

In its present form, the so-called empirical chart for liquefaction potential evaluation developed by Seed et al. (1984) has gained acceptance by the profession worldwide. Successful application of the chart to case histories of liquefaction and non-liquefaction not included in the development of the chart are abundant in the literature. However, in all cases, the liquefied sands are recent alluvial, beach, or deltaic deposits, and the materials themselves are granular clean sands, with silty fines in some cases. In fact, little documentation of liquefaction in deposits older than about 10,000 years appears to exist. In spite of that, engineers have been applying Seed et al.'s empirical relationships to assess liquefaction potential for both young and old deposits alike, even though recognition that an old sand deposit will exhibit more resistance to liquefaction than a younger deposit goes as far back as Youd and Hoose (1977), and Seed (1979).

Many factors are believed to explain this increase in liquefaction resistance due to age including cementation; weathering, (which chemically breaks down micas and feldspars into clays that inhibit liquefaction), increased exposure to low-level seismic shaking, cold bonding, and consolidation. In addition to increasing liquefaction resistance, most of these factors probably increase, to some degree, the SPT blow count.

To study the aging effect on liquefaction resistance, attention was directed to reviewing data from the Charleston, South Carolina earthquake of 1886 (Arango, Lewis, and Kimball, 1994 in press). This event took place in a setting with a multitude of liquefiable deposits of various ages, ranging from Holocene to greater than one million years.

The results of this analysis, along with studies that have been done onsite (RTF, 1993), suggest that older soil deposits (older than Holocene age, i.e., 10,000 years) have a greater resistance to seismic liquefaction than young (less than 10,000 years old) soil deposits. This has also been recently documented in a study by Martin and Clough (1994) who investigated liquefaction and non-liquefaction as a result of the 1886 Charleston earthquake.

For example, Figure 7-7 presents the combination of average penetration resistance and cyclic stress ratio induced by the 1886 Charleston earthquake that resulted in liquefaction or marginal liquefaction at 28 sites around the Charleston area. The plot is based on the assumption of a peak meizoseismal acceleration of $0.5 \mathrm{~g}$ for the 1886 Charleston earthquake. A low boundary curve for the minimum stress ratio (cyclic strength) values required to cause liquefaction shows cyclic strength increases relative to the clean sand curve.

Similarly, Figure 7-8 presents the combination of average penetration resistance and cyclic stress ratio induced by the 1886 Charleston earthquake that did not result in liquefaction or cause marginal liquefaction at 35 sites around the Charleston area. An upper boundary curve shows the maximum values of the stress ratio (cyclic strength) that were tolerated by the soil without widespread liquefaction. 
The conclusions reached by reviewing these two figures are that the sands in the Charleston area, which are about 100,000 to 200,000 years old, have significantly higher (about twice as much) cyclic strengths (i.e., greater resistance to liquefaction) than the younger Holocene sands which are depicted by the clean sand curve shown on each figure.

Seed (1979) presented data documenting the rate of cyclic strength gain with length of period under sustained load from the time of deposition as shown in Figure 7-9. In this figure, the strength increase from deposition to about 100 to 10,000 years (i.e., that for Holocene deposits in the empirical chart) is seen to be about 1.8 on the average. It follows that the gain in cyclic strength at time $T$, relative to the strength after 10,000 years is equal to:

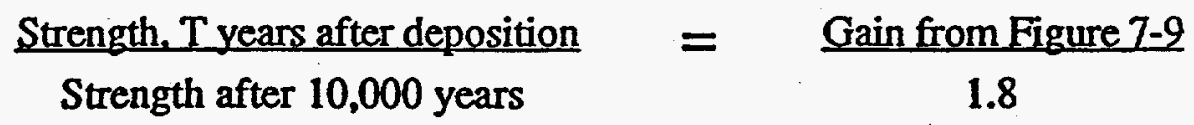

Based on this, the data points shown in Figure 7-9 were replotted as shown in .Figure 7-10. Superimposed on this figure are the strength gains corresponding to the sainds form the Charleston area (about 100,000 to 200,000 years old), and the Tobacco Road sands (about 30 million years old) at SRS.

The pattern of increased strength with time (i.e., aging in reality) is apparent in Figure 7-10, in particular for the clean sands representing the Charleston case histories, indicating that geologically older sand deposits do indeed have a greater resistance to liquefaction than implied by the empirical chart of Seed et al. (1984). More importantly, the laboratory-obtained cyclic strength of the old Miocene sand reflecting the combined effects of fines and aging falls within this pattern. Thus, laboratory testing can indeed provide reasonable strength results not only for young sands, but also for sands belonging to older deposits. In fact, the use of laboratory data is preferred for older deposits because of the limitations of the empirical chart. The use of laboratory-obtained cyclic strength data for the evaluation of the liquefaction potential at the site is presented in the next section.

\subsubsection{The Stress Method}

Based on the generalized profiles described in Section 5, a total of 7 soil columns were analyzed for the EBE (local and distant events) using the computer program SHAKE (Schnabel et al., 1972; Idriss and Sun, 1992). The field-measured soil shear wave velocity and site-specific straindependent soil properties obtained in the laboratory were used in this analysis. The cyclic shear stresses were compared with the cyclic shear strengths as measured in the laboratory and the factors of safety against liquefaction were computed for each soil column at 2-foot depth intervals. The factors of safety ranged from 1.4 at a few locations to values in excess of 4 . The majority of the safety factors were in excess of 2. Based on these factors of safety, it is concluded that liquefaction will not occur at ITP during the EBE. 


\subsubsection{The Strain Method}

Effective shear strains in the soil columns corresponding to the Tobacco Road, Dry Branch, and Santee Formation were obtained from the results of soil column ground response analyses (Section 7.2.4). These strain levels were compared with laboratory data relating the number of strain cycles and the corresponding increase in pore water pressure ratios (Section 7.3.1). For all 7 soil columns analyzed, an excess pore water pressure ratio of less than 12 percent is estimated. On this basis, it is concluded that liquefaction will not take place in the Tobacco Road, Dry Branch, and Santee Formation soils during the EBE.

\subsection{Settlement}

Future settlement at the ITP Tanks may occur in the following ways: (1) dynamic settlement due to dissipation of seismically-induced pore pressures, and (2) static settlement due to tank loading during operation and secondary consolidation .

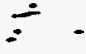

$\therefore=$

\subsubsection{Dynamic Settlement Due to Dissipation of Seismically-Induced Pore Pressure}

As discussed in Section 7.2, liquefaction will not occur at the ITP facility. However, partial pore pressure build up and subsequent dissipation and settlement will take place as a result of the EBE. These settlements were estimated based on the laboratory volumetric and threshold strain test. results.

For the Tobacco Road Formation, stress-controlled cyclic triaxial tests were performed. The field and laboratory data provided the means to derive the relationship between cyclic shear strength and cone tip resistance shown in Figure 7-11. These results, along with the volumetric strain test results, were used to develop a relationship between the factor of safety and volumetric strain. For factors of safety greater than 1.15 , the volumetric strains due to dissipation of pore water pressure increases were calculated based on recompression properties of the materials as determined by the laboratory consolidation tests. The relationship shown in Figure 7-12 was used to compute post-earthquake settlement for the Tobacco Road and Dry Branch Formations.

For the Santee Formation, seven low-amplitude stress-controlled cyclic triaxial tests were carried out. The results presented in Figure 7-13 show the relationship between induced pore water pressure and repeated cyclic strains of various amplitudes. The compression which results from the pore pressure dissipation was computed from the consolidation properties of the materials.

\subsubsection{Static Settlement due to Tank Loading during Operation and Secondary Consolidation}

Static settlement was determined by assessing field performance data at ITP and nearby facilities, in-situ testing, laboratory data, and analytical modeling. The following paragraphs describe and discuss the methodologies and conclusions. 
Best estimate laboratory-based soil properties are presented in Table 6-1. The results indicated that the sediments at the ITP are overconsolidated with an average OCR ranging from just over 1 for the deeper layers to over 4 for the TR2 layer. Insitu testing and the c/p relationship for normally loaded clays, however, indicate an even higher consolidation state for much of the profile. Utilizing the compression and re-compression indices and void ratios reported on Table 6-1 and the soft zone thicknesses reported in Section 5.4, the existing embankment and tanks should have settled more than one foot. Clearly, this has not occurred based on field settlement data and a simple visual inspection of the tanks and surrounding area. As noted by Peck (1954), "...the typical routine [of sampling, laboratory testing, and analysis] is often not conclusive, particularly in respect to settlements calculated on the basis of preconsolidation stresses determined from soil tests. Even with the best sampling and testing, an unnecessarily pessimistic view of the site emerges." Thus, settlements calculated in this manner are overly conservative. To quote Peck (1954): "Fortunately, because of the excellent case histories available, it is not necessary to base decisions upon theoretical considerations but rather upon observed facts."

The consolidation state of the profile has been thoroughly reviewed by other investigators at nearby SRS facilities who ultimately selected field performance data to predict settlement performance. D'Appolonia (1982) performed an extensive field and laboratory investigations for the Defense Waste Processing Facility (DWPF) and concluded that the soils were normally loaded and that more than 12 inches of settlement could be expected for the Vitrification Building (221 S). However, DuPont and their consultant Mueser et al, using tank settlement data in H-Area, concluded that the. $\mathrm{H}$ and S-Area soils had been preconsolidated and any post-construction settlement would be relatively small (about 3.5 inches) and that it would occur as a result of recompression. DuPont accepted this evaluation and established a post-construction settlement monitoring program in June, 1984 to verify the estimate. Excavation was completed by October, 1984 and the full structural loads were essentially in-place by January, 1988. As at July, 1994, the total cumulative settlement of the DWPF mat is less than 3 inches (see DWPF settlement curve in Figure 7-14).

The results of the DWPF settlement monitoring program demonstrates good agreement between prediction and performance. Thus, it may be concluded that the compressibility parameters derived assuming the soil column is overconsolidated (see Table 7-3 after Mueser et al., 1984b) are consistent with observed settlement behavior. Also, because these parameters were derived from actual tank performance in H-Area, they are appropriate for the estimation of the settlement of the ITP tanks. Utilizing the parameters given in Table 7-3, the predicted post-construction settlement due to placing the embankment and tanks is about 3 inches. Current settlement measurements on Tanks 48 - 51 at ITP show that the settlement is about $11 / 2$ to 2 inches, which is in good agreement with predicted performance (see ITP Tank 48 settlement curve in Figure 714). Furthermore, the settlement behavior of the ITP tanks is similar to that of DWPF (compare the two settlement curves in Figure 7-14). Also, the soil profile at DWPF is similar to the soil profile in H-area as noted by D'Appolonia (1979) in their "Site Comparison Report." Thus, it is concluded that the soil profile at the ITP, just like the DWPF profile, is overconsolidated and large underconsolidated soft zones do not exist, otherwise large settlements would have occurred. Therefore, recompression properties were used to predict future tank settlements due to increased 
fluid level during operation. In addition, the field performance data for Tanks 48-51 were used to predict long-term secondary consolidation or creep. .

\subsubsection{Settlement Summary}

Settlements were calculated based on free field response analyses results from representative stratigraphic soil columns extending from the ground surface to the Congaree Formation. The compression (dynamic settlement) of the soil column due to dissipation of pore water pressures ranges between 0 and 1 inch. Future tank settlement due to increased fluid level during operation is estimated as 3/4 of an inch. For this estimate, the compression characteristics of the soils, backfigured from actual field performance, were utilized. Long-term (over a 30-year time period) settlement of tanks due to secondary (thixotropic) effects is estimated to be $1 / 2$ of an inch.

Summing the results, the total settlement at the tank foundation level is slightly less than $21 / 2$ inches. Because the total settlement is small, a settlement profile was not determined. However, it can be assumed that the differential settlement (edge to edge of tank) will be about 50 percent of the total.

\subsection{Worst Case Settlement}

\subsubsection{Introduction}

At other areas within the SRS, it has been assumed that the Santee Formation, or zones within it, are underconsolidated. The estimated amount of underconsolidation has ranged from less one half of overburden pressure to normally loaded (GEI, 1991 and KASS, 1992). Laboratory and field tests at the ITP do indicate the existence of "soft zones" or underconsolidated "pockets" . within the Santee Formation. The amount of underconsolidation probably ranges from about 0.5 to 1.0. Field moisture content data and analytical modeling suggest that the soft zones have an average overconsoldation ratio of about 0.7 .

Field evidence at the ITP also supports the conclusion that the soft zones are actually pockets and that the lateral extent of any given pocket is small; for if it were large, significant settlement would have occurred during the placement of the embankment. This conclusion is also supported by the findings of the field exploration program. A review of the adjacent SPT and CPT penetration resistances for closely paired boreholes suggests that the lateral extent of any given pocket is generally less than a few tens of feet (Section 5.3). Previous work at other SRS areas also suggests that these soft zones are small (COE 1952a, 1952b; GEI, 1991; KASS, 1992). Those studies concluded that the size of the postulated underconsolidated zones is small, not interconnected, and average about six feet thick with lateral dimensions less than 50 feet. Also, analytical modeling indicates that soft zones with lateral dimensions greater than about 50 feet could not exist (Kass, 1992). A zone of that size would have caused "collapse" to occur due to the inability of the overlying materials to bridge the soft zone. 
However, analyses have been done for other facilities at SRS assuming that the underconsolidated pockets are "arched over" by more competent materials within the Santee Formation. The same approach was followed for the ITP facility.

For this analysis, and using the computer code FLAC (1993), the generalized profiles AA and BB (Figures 5-1 and 5-2) were modeled as shown in Figures 7-15 and 7-16. All factors influencing the stress regime in the soil layers below the 'tanks were considered. These are: (1) stratigraphy of the site, (2) soft zone geometry, (3) redistribution of stresses and its effect on the soft zones after fill and tank placement, (4) soil nonlinear and dilatational behavior with possible large deformation. The code is capable of addressing these factors and nonlinear large strain analysis of soil, using the fast lagrangian techniques. In profile $\mathrm{BB}$, the soft zones were modeled on the eastern side of Tank 49 as characterized by the field data. For profile AA, however, soft zones are considered continuous under Tank 51 extending to the north beyond the tank foundation.

Using these models and representative soil parameters, the construction sequence yias-simulated by placing the fill and tank structures on top of the Tobacco Road layer. Both empty and full tank conditions were considered. A total settlement on the order of 2 inches due to placement of the embankment load was computed. This settlement is in close agreement with the recorded settlement at the site, (i.e., 1-1/2 to 2 inches), thus confirming the adequacy of the model and the previous re-compression soil properties used in the analysis.

The analysis also provided the distribution of normal stresses in the subsurface. Based on these stresses, the state of stress in the soft zones was evaluated and compared to the effective overburden pressure at the respective depths. The results show the soft zones - were underconsolidated by a ratio of 0.65 to 0.75 . This range compares favorably with the laboratory data for the soft zones, which shows the value of overconsolidation ratio $(O C R)$ is about 0.7 , underscoring once again the adequacy of the selected model and material properties.

For the tank settlement analysis under post-earthquake conditions, an OCR of 0.70 was used to calculate compression. Using this OCR, and the appropriate compression index, about 4 to 7 inches of compression within the Santee Formation was calculated for a 10 and 15-foot-thick soft zone, respectively. This calculation is based on the conservative assumption that the soft zones will "feel" the full effective overburden pressure and no arching effects exist following the earthquake..

\subsubsection{Post-Earthquake Tank Settlement Analysis}

To predict post-earthquake tank settlement profiles, the compressions of all soil layers and soft zones were computed and used as loadings to the post-earthquake FLAC analysis described in the four steps outlined below.

1. Pre-earthquake stress conditions in the field were simulated using the program as described in Section 7.4.1. These results were used to predict the potential compression of soft zones should the full overburden pressure be transferred to the soft zones at depth. 
2. Two-dimensional seismic soil-structure interaction (SSI) analyses were performed using the computer program SASSI (1988) to compute the maximum shear stresses and strains induced in the supporting soil foundation by the EBE. In these analyses, the effect of tank-soil-tank interaction as well as the sloping boundaries between the soil layers on the stress results were considered.

Field measured soil properties including the low-strain shear wave velocity and laboratoryobtained strain-dependent soil properties were used in SASSI. The analyses were performed for the EBE for empty and full tank conditions. The SSI results were also used to develop earthquake loading for slope stability analysis as discussed in Section 7.1. In addition, the seismic soil pressures under the tank foundation were also obtained for structural evaluations of the tank foundation mat.

3. Using the field and laboratory data discussed in Section 7.3.1, the volumetric strain behavior characteristics of the foundation soils were determined as a function of CPT tip resistance and friction ratio. To recognize the inhomogeneity of the soil properties, the CPT data were interpolated using geostatistical techniques (i.e., kriging).

4. Using the results of steps 1,2 , and 3, the volumetric change and the compression of each soil element in the FLAC model were computed. This step was repeated for both profiles AA, BB, and for the two EBE with full and empty tank conditions.

\subsubsection{Worst Case Settlement Estimates: Summary}

Using the element compression results along with the conservative estimate of soft zone compression, the models shown in Figures 7-15 and 7-16 (profiles AA and BB) were analyzed to determine the settlement at the tank foundation level. A summary of the maximum total and differential settlement for each tank determined from the post-earthquake analysis is presented on Table 7-4.

Based on the results of the analyses, foundation settlement profiles were deveioped. A "worstcase" settlement profile for the ITP tanks (Tank 50) was obtained from FLAC (Figure 7-17). The analysis assumed a soft zone up to 15 feet thick resulting in a maximum soft zone compression of approximately 7 inches at depth. The maximum computed differential settlement across the width of the tank is slightly less than 2 inches.

\subsection{CONCLUSIONS}

Field, laboratory, field performance data, geological, seismological, and geotechnical engineering investigations have been completed which provided the necessary data for evaluating the performance of the subsurface soil materials around and beneath the ITP facility under both static and dynamic loads. The subsurface conditions were characterized based on a series of investigations which included borings, cone soundings, dilatometer soundings, geophysical surveys, cross hole seismic surveys, surface seismic surveys, field performance data, laboratory 
testing and utilizing data from previous studies. at the SRS. Based on presently available data, the following conclusions are made:

1. The applicability of the EBE soil spectra was evaluated for use at ITP. Based on available data, application of the K-Reactor spectra (EBE) at the ITP facility provides at least the same degree of conservatism in ground motion during an earthquake as was developed for K-Reactor. Consequently, the EBE controlling spectra are judged acceptable for the ITP deterministic geotechnical evaluation. The contribution to risk of the EBE soil spectra and the ITP 84th percentile spectrum will be evaluated in the probabilistic analysis.

2. The calcareous lithofacies in the General Separations Area (GSA) is discontinuous, but confined to three distinct stratigraphic horizons of different ages and depositional setting. The carbonate buildups appear to be oriented northeast-southwest, paralleling the strike of the shoreline at the time of deposition.

3. The soft -zones that have occurred during drilling, typically occur in the :carbonate-rich sediments in the Santee Limestone, Utley Limestone, and the lower portions of the Dry Branch Formation. The soft zones are associated with well-cemented silicified units (hard grounds) and occur in the "soft zones" commonly found below the silicified unit. The hard grounds and underlying "soft zones" were probably formed in the time frame of the development of the unconformity at the end of Santee time (40-43 mybp), in proximity to the water table existing at the time. It appears that the "soft zones" are sediment filled, most likely with fine-grained, wellsorted sand.

4. At the present time, the top of the Santee in the GSA, approximately 150 feet below ground surface, is well below the water table. For much if not most of the period since the end of Santee deposition, the above described diagenetic alteration to both the carbonate and clastic sediments has in all likelihood been negligible.

5. Two types of faults are commonly observed in the GSA along the flanks of the carbonate buildups. The first, suggests faulting that occurred in response to slumping of the sediments above the carbonate buildups where differential dissolution of the carbonate interval occurred. The second, suggests preferential dissolution of carbonate associated with existing deep-seated tectonic faults, without necessarily compacting the interval where carbonate was dissolved. Both types of fault mechanisms are thought probable in the GSA. Detailed stratigraphic data suggests that displacement of the sedimentary section along the slump induced faults occurring near the dissolved carbonate horizons was a gradual, slow subsidence event, rather than a sudden movement.

6. Slope stability analyses for the embankment fill were completed for static and pseudo-static conditions. The results of the analyses show that the embankment slopes are stable under all conditions. The static (long term) factor of safety is 1.9 for effective stress conditions. Under short term earthquake loading, the pseudo-static factor of safety is greater than 1.5 for all cases, with a yield acceleration of $0.6 \mathrm{~g}$. Predicted deformations of the slopes are negligible. 
7. The liquefaction potential of the soils at the site was evaluated both qualitatively and quantitatively. The results showed that neither the Tobacco Road nor Dry Branch Formations are susceptible to liquefaction. Measured shear wave velocities, grain size, and plasticity results from each formation show that the potential for seismic liquefaction is extremely low. Quantitatively, both the stress and strain approaches show that the potential for seismic liquefaction in the Tobacco Road, Dry Branch, and Santee Formations is negligible. Factors of safety against initial liquefaction range from 1.4 to over 4, most values being greater than 2 .

8. A pragmatic assessment of tank settlement was performed using actual measured performance data. Based on evaluation of this data and analyses, it is concluded the soils at the ITP are overconsolidated and large continuous soft zones do not exist. Thus, tank foundation settlement was evaluated considering dynamic settlements due to the EBE; additional static settlement due to fluid loading in the tanks during operation, and long-term secondary settlement. The results show that dynamic settlements are less than 1 inch, static settlement due to increased operating loads is about $3 / 4$ inch, and long-term secondary settlement is about $1 / 2$ inch. The resulting total tank settlement ranges from 2 to $2-1 / 2$ inches.

$\therefore=$

9. Additional settlement analyses was performed assuming soft zones within the Santee Formation are underconsolidated, laterally large and continuous, and up to 15 feet thick. Worst condition results show that if transfer of load occurs to the soft zones as a result of cyclic loading, then the compression within the soft zones would range from about 4 to 7 inches. Analyses that combine dynamic compression due to dissipation of excess pore water pressure with the postulated compression of the soft zones result in maximum tank foundation settlement of 5 inches (Tank 51) and a maximum differential (edge to edge) settlement of 2 inches (Tank 50). 


\section{REFERENCES}

Arango, I., Lewis, M. R., and Kimball, J. K. (1994, in press) "Seismic Liquefaction-Field Performance Data and the SPT: Review and Commentary on Their Bases and Limitations."

Bechtel Savannah River, Inc. (1993), “Savannah River Site, H-Area In-Tank Precipitation Facility, Geotechnical Investigation Report, Preliminary Assessment (U)," March.

D' Appolonia (1982), "Balance of Plant Geotechnical Report, Defense Waste Processing Facility 200-S Area Savannah River Plant South Carolina," Project No. 76-372, Jan..

D’ Appolonia (1979), “Site Comparison Report, Defense Waste Processing Facility Savannah River Plant," Project No. 76-372-K3, Oct.

Ebasco Division (1994a), Raytheon Engineers and Constructors, WSRC Project Engineering Services Contract, "In Tank Precipitation Facility, Task 176, Final Report,_Phase I and II Cone Penetrometer Studies," March 10.

Ebasco Division (1994b), Raytheon Engineers and Constructors, WSRC Project Engineering Services Contract, "In Tank Precipitation Facility, Task 176, Final Report, Geophysical Investigations," March 30.

FLAC - (1993) Fast Lagrangian Analysis of Continua; Computer Program FLAC - Itasca Consulting Group Inc., Minneapolis, Minnesota.

Field, M.E. and Duane, D. B. (1974), "Geomorphology and Sediments of the Inner Continental Shelf, Cape Canaveral, Florida," U.S. Army Corps of Engineers Coastal Engineering Research Center, Technical Memorandum 42,87 p.

Geometrix (1991). Ground motion following selection of SRS design basis earthquake and associated deterministic approach, WSRC subcontract AA20210S.

Geotechnical Engineers Inc. (1991), "Geotechnical Investigation for Seismic Issues-Technical Evaluation," WSRC TR-91-47, March.

HLW-ENG-930017 (1994), “H-Area/TTP Seismic Safety Issue Resolution Program Plan,” Rev. 1, Jan. 31.

Idriss I. M . and Sun J. I. (1992), “User's Manual for SHAKE 91," University of California, Davis, November.

KASS (1992), "K-Area Soil Stabilization Program, Geotechnical Evaluation.” WSRC TR-92-299 July.

Kayen, R. E., J. K. Mitchell, R. B. Seed, A. Lodge, S. Nishio, and R. Coutinno (1992), "Evaluation of SPT-CPT- and Shear Wave-Based Methods for Liquefaction Potential Assessment Using Loma Prieta Data," Proceedings from the Fourth Japan - U. S. Workshop on Earthquake Resistance Design of Lifetime Facilities and Counter Measures for Soil Liquefaction, Volume 1, 
Koester, J. P. , and A. G. Franklin (1985), "Current Methodologies for Assessing the Potential for Earthquake-Induced Liquefaction in. Soils," NUREG/CR-430, U. S. Regulatory Commission, Washington, D. C.

Law Engineering, Inc. (1994), "Final Report for ITP Geotechnical Services," Law Engineering Project Number: 5810535301, WSRC sub-contract no. AB08525N. February 21.

Martin, J. R., and Clough, G. W. (1994) "Seismic Parameters From Liquefaction Evidence," Journal of Geotechnical Engineering, ASCE Vol. 120, No. 8, August, 1994.

Makdisi and Seed (1978), “A Simplified Procedure for Estimating Earthquake Induced Deformations in Dams and Embankments," EERC-77/19.

Mueser, Rutledge, Wentworth, and Johnston (1977), "Building 241-H, New High Level Waste Storage Tanks Nos. 48 through 51," Savannah River Plant, Report, March 22.

Mueser, Rutledge, Johnston, and Desimone (1978), "Building 241-H, New High Level Waste Storage Tanks Nos. 50 and 51," Savannah River Plant, Report, May 23.

Mueser, Rutledge, Johnston, and Desimone (1984a), "In-Tank Precipitation Facility ì-Area Savannah River Plant," Savannah River Plant, Report, Aug. 27.

Mueser, Rutledge, Johnston, and Desimone (1984b), "Geotechnical Report, Design and Construction, Defense Waste Processing Facility, 200-S Area, Savannah River Plant," Aug. 7.

Peck, R.B. (1954), “Report on Foundation Conditions, Distribution Center for Safeway Stores, Inc., Salt Lake City, Utah" Judgment in Geotechnical Engineering, Ed. Dunnicliff and Deere, BiTech Publisher Ltd., Vancouver, B.C, 1977.

Raymond International, Inc. (1976), Test Boring Report, Savannah River Plant, Boreholes 241$12 \mathrm{H}-20$ through $241-12 \mathrm{H}-30$, Job No. EB 25197-DC.

RTF (Replacement Tritium Facility), Bechtel Savannah River, Inc. (1993), "Savannah River Site Replacement Tritium Facility (233H) Geotechnical Investigation (U)," WSRC-RP-93606, April.

SASSI - (1988) Soil-Structure Interaction Analysis - Computer Program, Bechtel Western Power Corporation, San Francisco, Ca.

Schnabel, P. B., Lysmer J. and Seed H. B. (1972), "SHAKE-A Computer Program For Earthquake Response Analysis of Horizontally Layered Sites," Report No. EERC 72-12, University of California, Berkeley, Dec.

Seed, H. B. (1979), "Soil Liquefaction and Cyclic Mobility Evaluation for Level Ground During Earthquakes," Journal of Geotechnical Engineering Division, ASCE, Volume 105, Number 2, February.

Seed, R. B., Idriss, I. M. and Arango, I. (1983), "Evaluation of Liquefaction Potential Using Field Performance Data," Journal of Geotechnical Engineering Division, ASCE, Volume 97, Number 3. 
Seed, R. B., and Harder, L. F. Jr. (1990), "SPT-Based Analysis of Cyclic Pore Pressure Generation and Undrained Residual Strength," H. Bolton Seed Memorial Symposium Proceedings, Vol. 2., Vancouver, B.C., Canada.

Seed, H. B., Tokimatsu, K., Harder, L. F., and Chung, R. M. (1984), "The Influence of SPT Procedures on Soil Liquefaction Resistance Evaluations, "Report No. UCB/EERC84/15, Earthquake Engineering Research Center, University of California, Berkeley, CA, Oct., 1984.

Siple, G. E. (1967) "Geology and Ground Water of the Savannah River Plant and Vicinity, South Carolina," U.S. Geological Survey Water Paper 1841.

Stokoe, K. H., G. R. Rix, I. Sanches, R. D. Andrus, and Y. J. Mok (1988) Liquefaction of Gravely soils During the 1983 Borah Peak, Idaho Earthquake," Proceedings of the Ninth World Conference On Earthquake Engineering, Tokyo, Japan, Volume III, August.

Toro, G.R., N.A. Abrahamson, and J.F. Schneider (1994). Engineering model of stróng ground motions from earthquakes in the central and eastern United States, submitted to Earthquake Spectra, March, 1994.

URS/John A. Blume and Associates, Engineers (1982). Update of Seismic Criteria for the Savannah River Plant, vol. 1 of 2, Geotechnical: URS/JAB 8144, 293 pp.

US Army Corp of Engineers, Charleston District (COE) (1952a), "Geologic Engineering Investigations, Savannah River Plant," Volumes 1 and 2, Waterways Experiment Station, Vicksburg, MS.

US Army Corp of Engineers, Charleston District (COE) (1952b), "Foundation Grouting Operations, Savannah River.Plant," Volumes 1 and 2, Waterways Experiment Station, Vicksburg, MS.

U.S.G.S. Open File Report No. 94-181, "Preliminary Geological Map of the Savannah River Site, Aiken, Allendale, and Barnwell Counties, South Carolina

Wang, W. (1979), "Some Findings in Liquefaction," Water Conservancy ard Hydroelectric Power Scientific Research Institute, Beijing, China, August.

WSRC 1Q Manual(1990), "Westinghouse Savannah River Company Quality Assurance Manual," August 31.

Youd, T. L., and Hoose, S. N. (1977) "Liquefaction Susceptibility and Geologic Setting," Proceedings, 6th World Conference on Earthquake Engineering, New Delhi, India, Vol. 6, pp. 37-42. 
Site Geotechnical Services

WSRC-TR-94-0369, Rev. 0

In Tank Processing (ITP) Geotechnical Summary Report

July 29, 1994

i:

TABLES

34 
Table 2-1

Chronology of Geologic Events Showing the Depositional History (youngest to oldest) in the Vicinity of the $\mathrm{H}$-Area Tank Farm

YOUNGEST (probably younger than 10 mybp ?*)

- Faulting occurred that offset and affected the distribution of carbonate in the Santee, Utley, and Dry Branch formations. The faulting may have resulted both from the most recent reactivation of the tectonic faults in the area, and by slumping associated with dissolution of the carbonate in the Santee and Dry Branch formations.

- Deposition of the Upland Unit (approximately 10 mybp?*)

- Deposition of the Tobacco Road Formation in paralic to non-marine environizents.

- Deposition of the Dry Branch Formation including the Griffins Landing limestone member, in a paralic depositional environment.

- Deposition of the Clinchfield Formation including the Utley Limestone Member in a shallow shelf environment.

- Major erosional/nondepositional unconformity following Santee deposition. This is the probable time frame when the hard grounds and soft zones developed in the underlying Santee Formation.

- Deposition of the Santee Carbonates and clastics of the Tinker Formation in shallow shelf depositional environments.

- Deposition of the Warley Hill clays in deeper shelf depositional environments.

- Deposition of Congaree sands in shoreline depositional environments.

\section{OLDEST (approximately 50 mybp)}

* If Upland Unit is proven to be offset by the regional faulting (most probable); then faulting post-dates Upland Unit deposition. Therefore, age of faulting is less than 10 mybp. If Upland Unit is not offset by the regional faulting (less probable), then faulting pre-dates Upland Unit deposition and the faulting must be older than 10 mybp. 
TABLE 4-1 TRIAXIAL LABORATORY TESTING PROGRAM

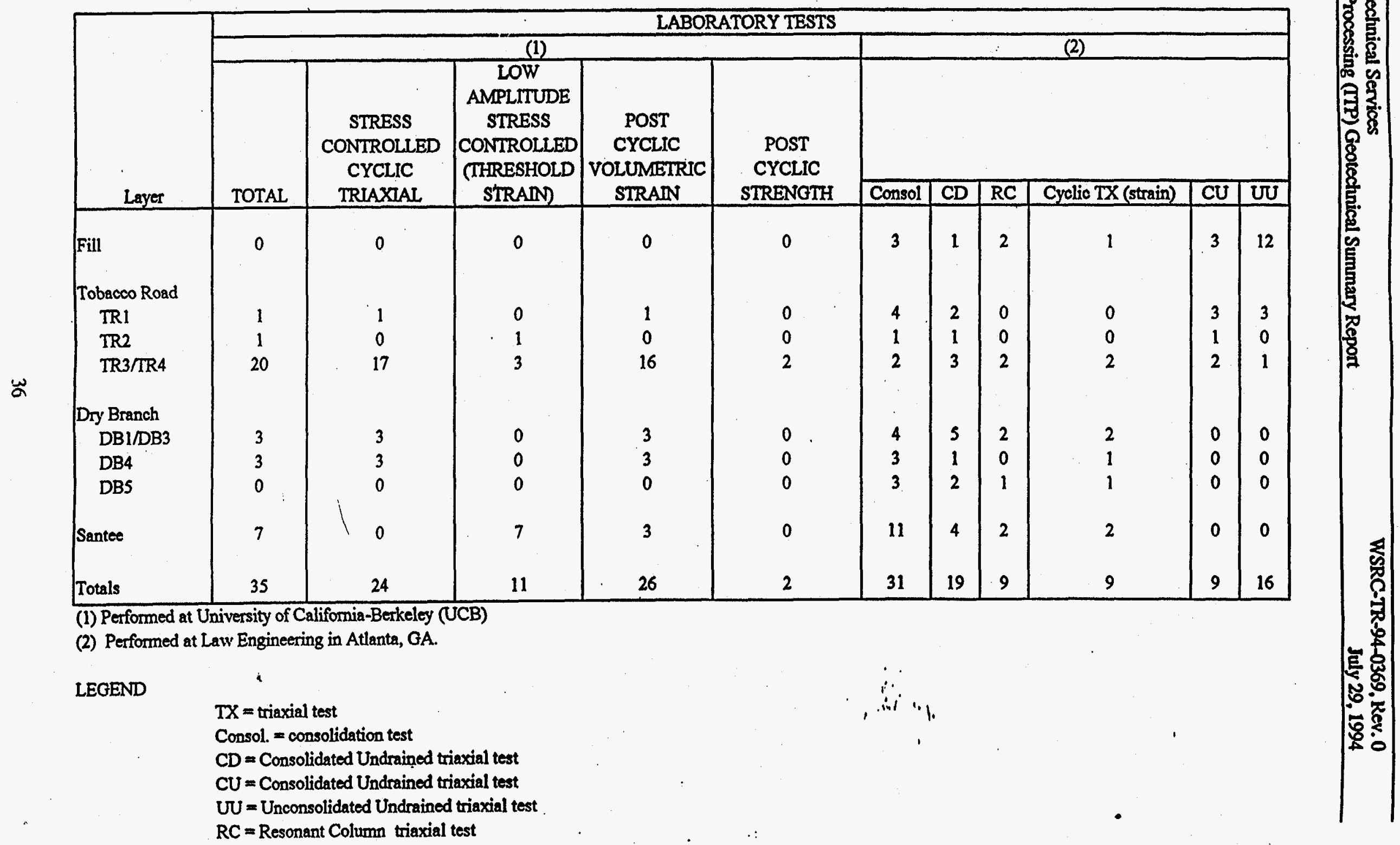




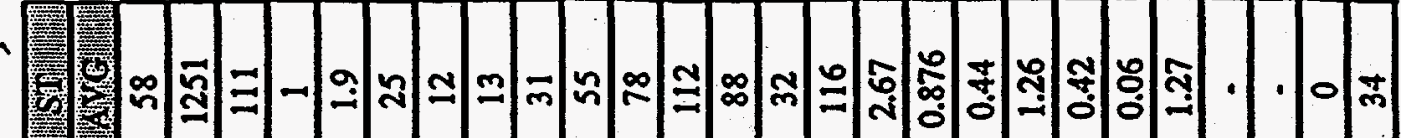
$=$

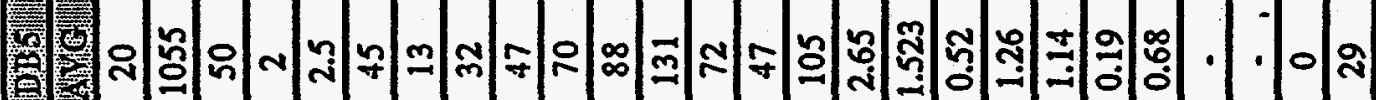

\section{$\sum \pm$}

\section{.}

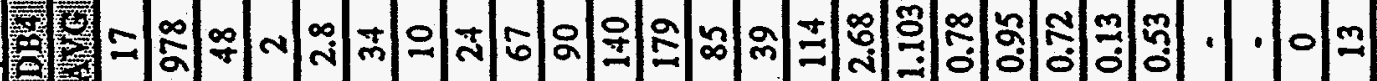
慧

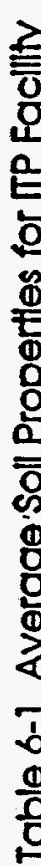

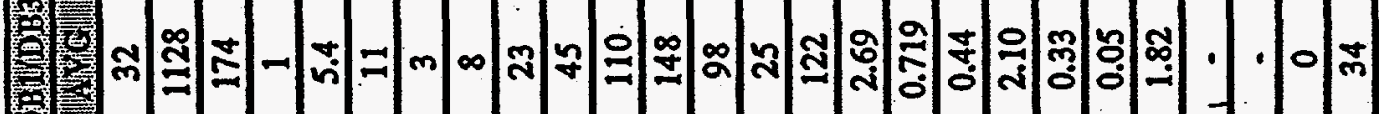

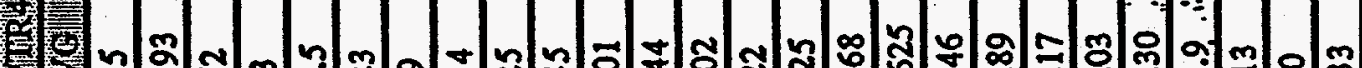

鹪

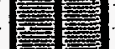

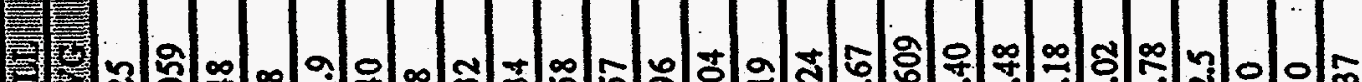

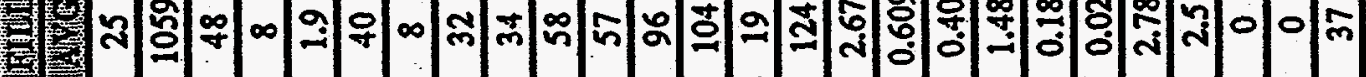

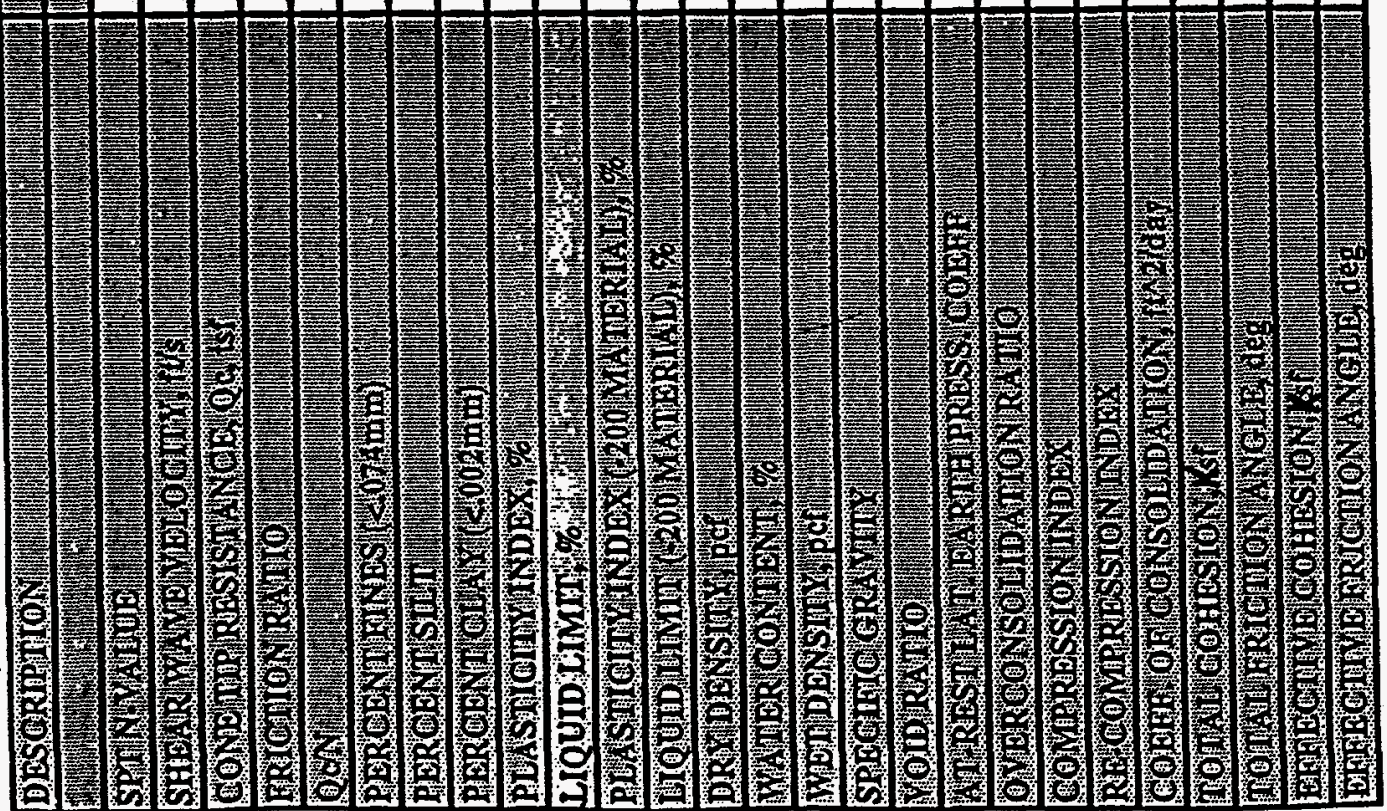


Table 7-1

Best Estimate Shear Strength Parameters for Slope Stability Analysis

\begin{tabular}{lllllll}
\hline Layer & $\begin{array}{l}\text { Thickness } \\
\text { (ft) }\end{array}$ & $\begin{array}{l}\text { Unit } \\
\text { Weight } \\
\text { (pcf) }\end{array}$ & $\begin{array}{l}\text { Effective } \\
\text { Stress } \\
\text { Friction } \\
\text { Angle } \\
\text { (deg.) }\end{array}$ & $\begin{array}{l}\text { Effective } \\
\text { Stress } \\
\text { Cohesion } \\
\text { (psf) }\end{array}$ & $\begin{array}{l}\text { Total } \\
\text { Stress } \\
\text { Friction } \\
\text { Angle } \\
\text { (deg.) }\end{array}$ & $\begin{array}{l}\text { Total } \\
\text { Stress } \\
\text { Cohesion } \\
\text { (psf) }\end{array}$ \\
\hline Fill 1 & 38 & 121 & 37 & 0 & 0 & 3785 \\
Fil 2 & 2 & 115 & 19 & 0 & 0 & 1703 \\
TR1 & 16 & 121 & 34 & 0 & 16 & 1000 \\
TR2 & 20 & 126 & 29 & 0 & 23 & 1500 \\
TR3 & 20 & 124 & 30 & 0 & 13 & 1900 \\
\hline
\end{tabular}


Table 7-2

Average and Normalized Shear Wave Velocities for the ITP Soil Columin

\begin{tabular}{lcccc}
\hline Formation & $\begin{array}{c}\text { Depth to middle } \\
\text { of layer (ft) }\end{array}$ & $\begin{array}{c}\text { Avg. } \\
\text { Wave (ft/sec) }\end{array}$ & $\begin{array}{c}\text { Shear } \\
\text { (ft/sec) }\end{array}$ & $\begin{array}{c}\text { Normalized Velocity } \\
\text { (m/sec) }\end{array}$ \\
\hline Fill & & - & - & - \\
Tobacco Road 1 & 59 & 1187 & 878 & 268 \\
Tobacco Road 2 & 81 & 1226 & 866 & 264 \\
Tobacco Road 3/4 & 98 & 1193 & 818 & 249 \\
Dry Branch 1/3 & 125 & 1128 & 741 & 226 \\
Dry Branch 4 & 145 & 978 & 626 & 191 \\
Dry Branch 5 & 158 & 1055 & 667 & 203 \\
\hline
\end{tabular}


Table 7-3

Soil Parameters Used in Settlement Analysis (afier Mueser et al., 1984b)

\begin{tabular}{|c|c|c|c|c|c|c|}
\hline \multirow[b]{2}{*}{ Stratum } & \multirow[b]{2}{*}{$\begin{array}{c}\text { Corresponding } \\
\text { Layer }\end{array}$} & \multirow[b]{2}{*}{$\begin{array}{l}\text { Unit Weight } \\
\therefore \text { (pct) }\end{array}$} & \multirow{2}{*}{$\begin{array}{c}\text { Average } \\
\text { Water Content } \\
(\%)\end{array}$} & \multicolumn{3}{|c|}{ Consolidation Parameters } \\
\hline & & & & $\begin{array}{c}\text { Compression } \\
\text { Index } \\
\left(C_{c}\right)\end{array}$ & $\begin{array}{l}\text { Recotöpression } \\
\text { Itdex } \\
\left(C_{r}\right)\end{array}$ & $\begin{array}{c}\text { Initial Void } \\
\text { Ratio } \\
\left(e_{0}\right)\end{array}$ \\
\hline S1 & TR1 & 130 & 21 & - & 0.009 & 0.56 \\
\hline $\mathbf{S 2 a}$ & TR2, TR3/TR4 & 128 & 22 & - & 0.008 & 0.59 \\
\hline$S 2 b$ & DB1/DB3 & 128 & 22 & - & 0.009 & 0.59 \\
\hline$C_{2}$ & DB4, DB5 & 106 & 53 & $0.85^{*}$ & 0.070 & .1 .4 \\
\hline $\begin{array}{c}\text { S3a } \\
\text { (Elev. } 180 \text { to 200) }\end{array}$ & ST & 127 & 23 & - & 0.009 & 0.62 \\
\hline $\begin{array}{c}\text { S3a } \\
\text { (Elev. } 130 \text { to } 180 \text { ) }\end{array}$ & ST & 121 & 30 & - & 0.015 & 0.80 \\
\hline
\end{tabular}

* Was not used. The stress induced in this layer never exceeded the preconsolidation pressure. 
Table 7-4

Tank Settlement

\begin{tabular}{ccc}
\hline Tank & $\begin{array}{c}\text { Maximum Total Settlement } \\
\text { (in) }\end{array}$ & $\begin{array}{c}\text { Differential Settlement for } \\
\text { Full Tank Diameter (in) }\end{array}$ \\
\hline 48 & $<0.5$ & $<0.5$ \\
49 & 1 & $<1$ \\
50 & 4 & 2 \\
51 & 5 & $<1$ \\
\hline
\end{tabular}




\section{FIGURES}

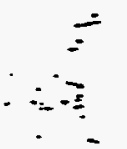



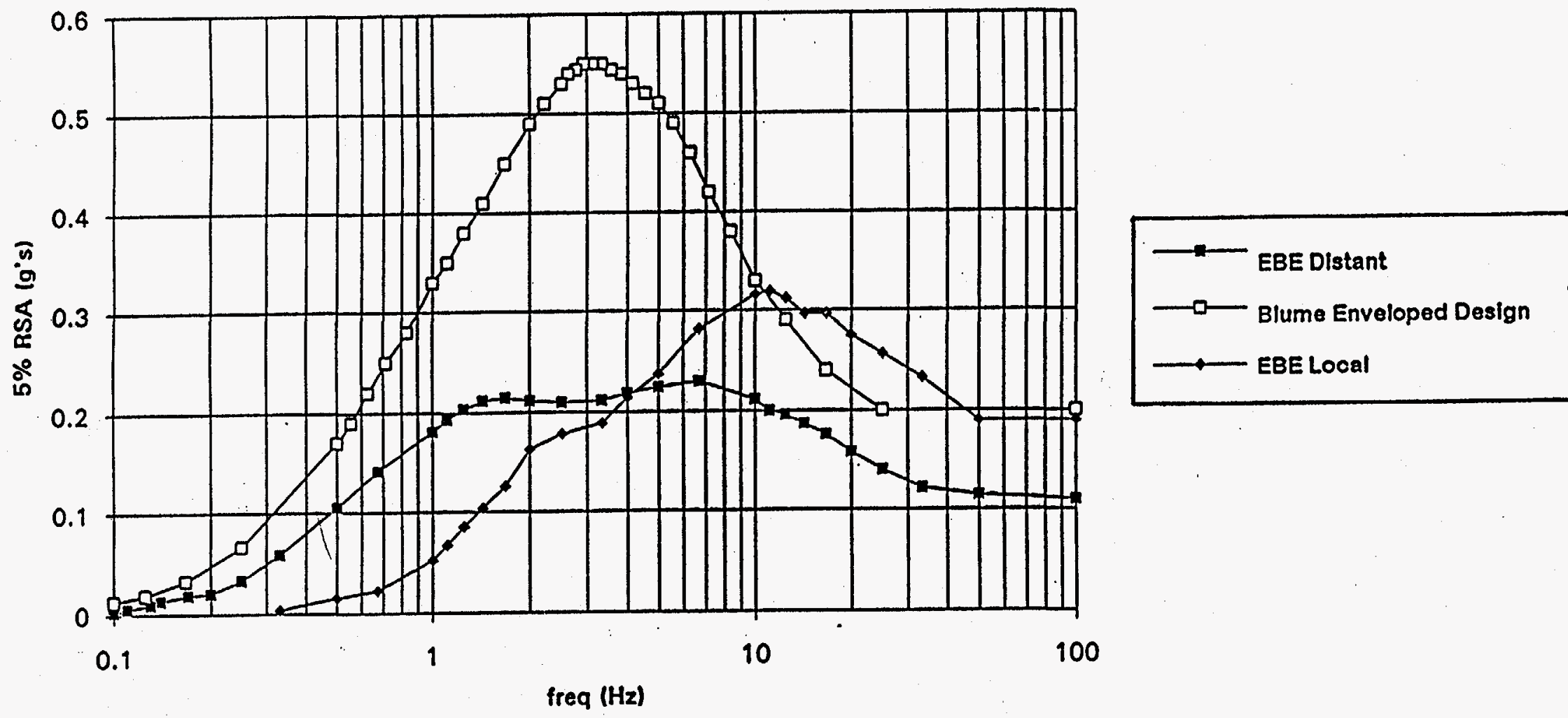


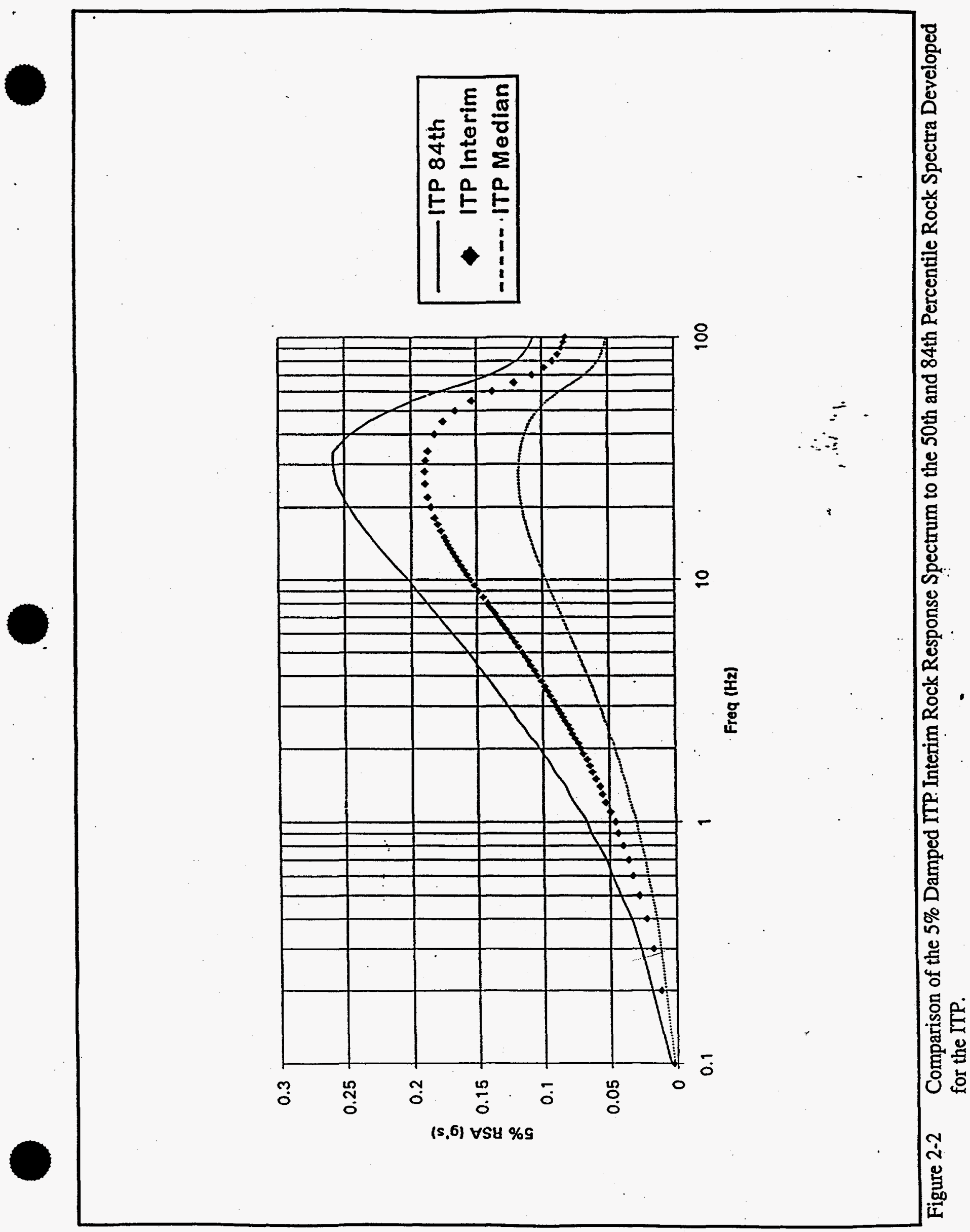




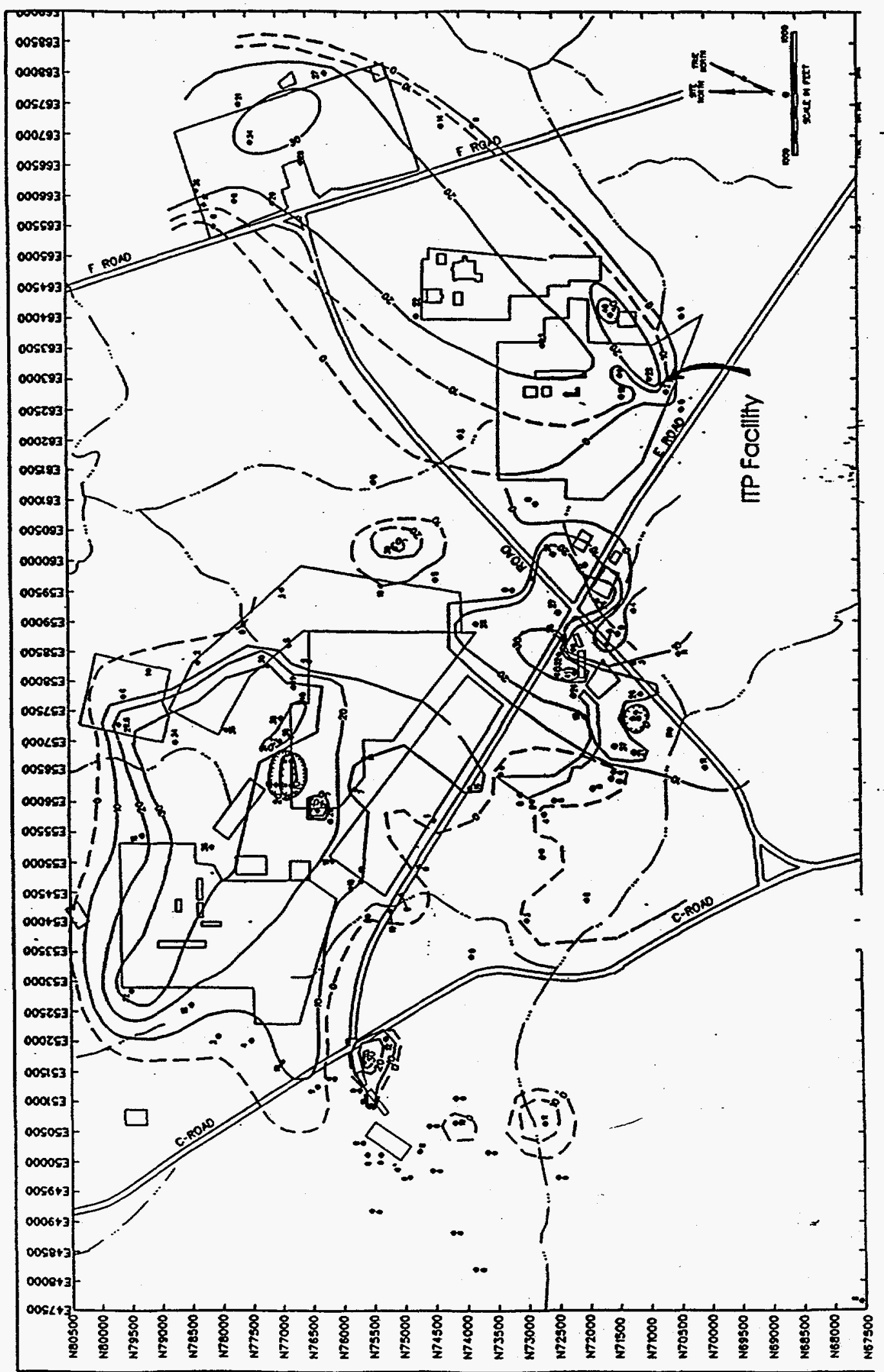

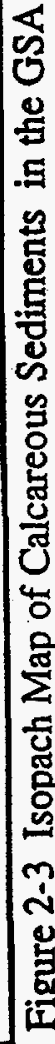




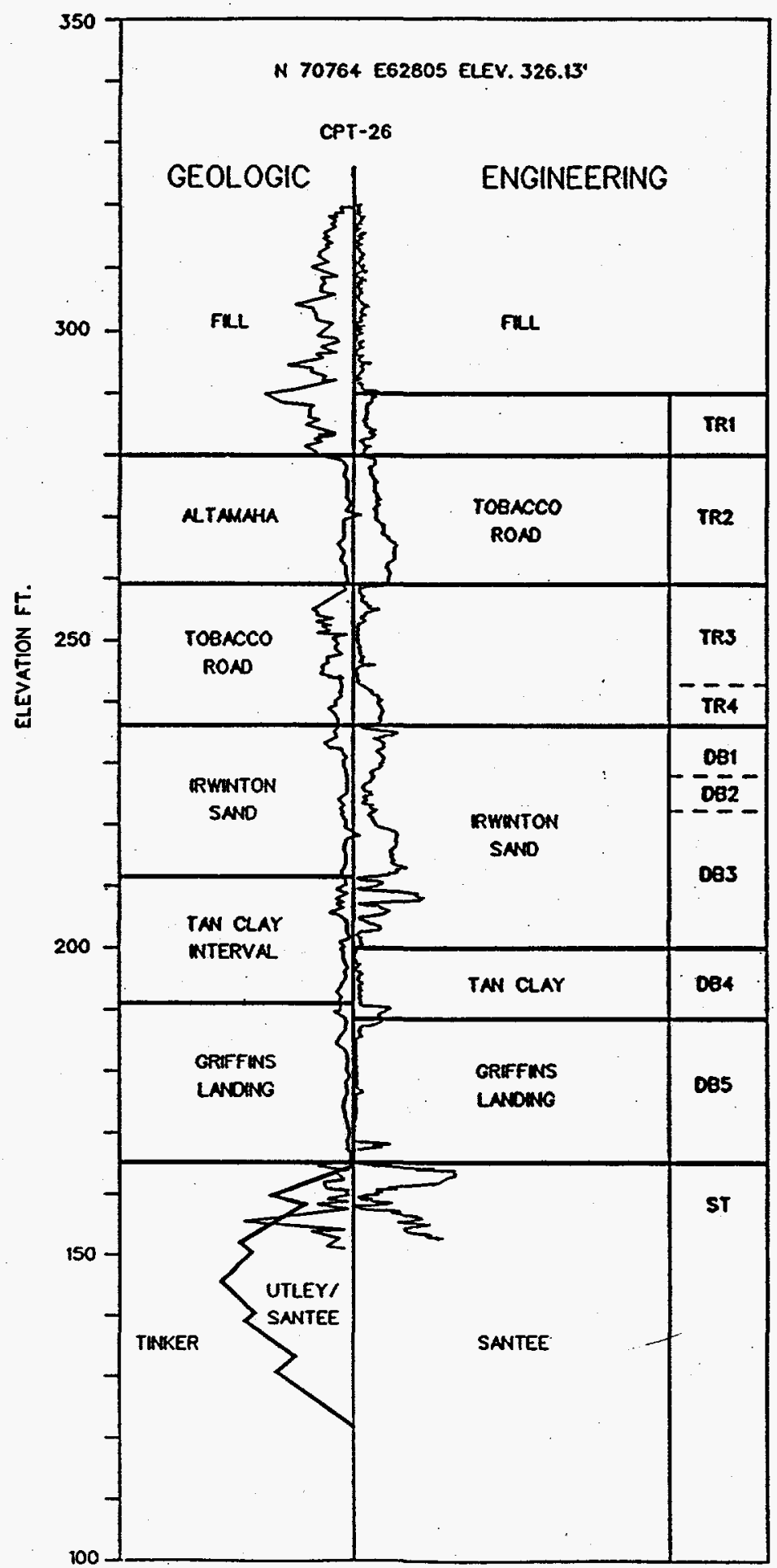

Figure 2-4 Comparison of Nomenclature 


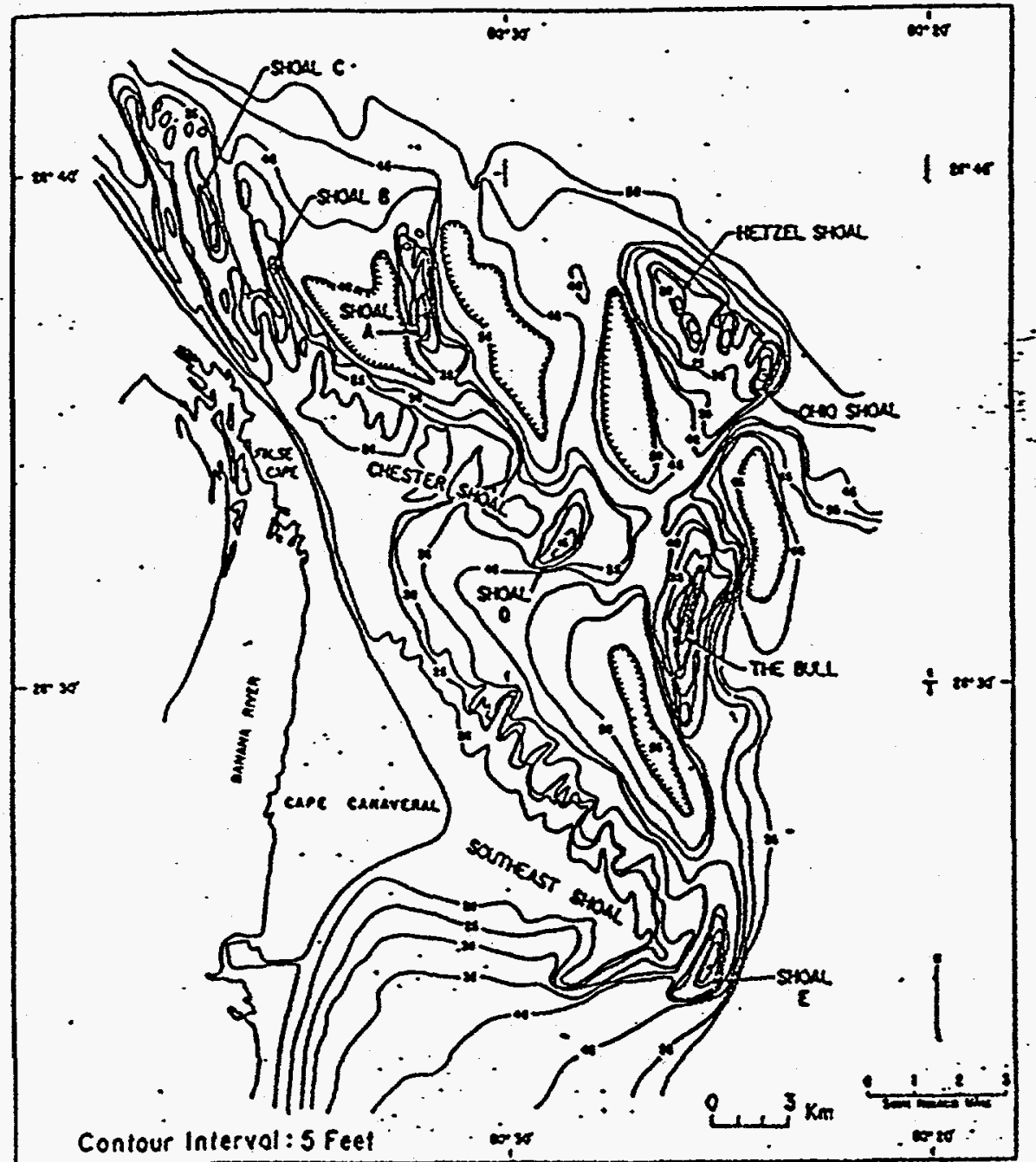

Figure 2-5 Map of Shelfal relief Around Cape Canaveral, Florida. Modern Analog for Depositional Setting of the Santee Limestone After Field and Duane, 1974. 
LEGEND:

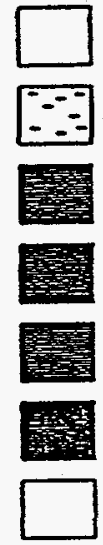

SNO LOCNLY COMGLOMERATC

cuarer/sutr sano

aAr

CLaY, sutr car

UWESTOAE

CALCAREOUS SADO

NO RECOVERY

VERTICAL SCALE

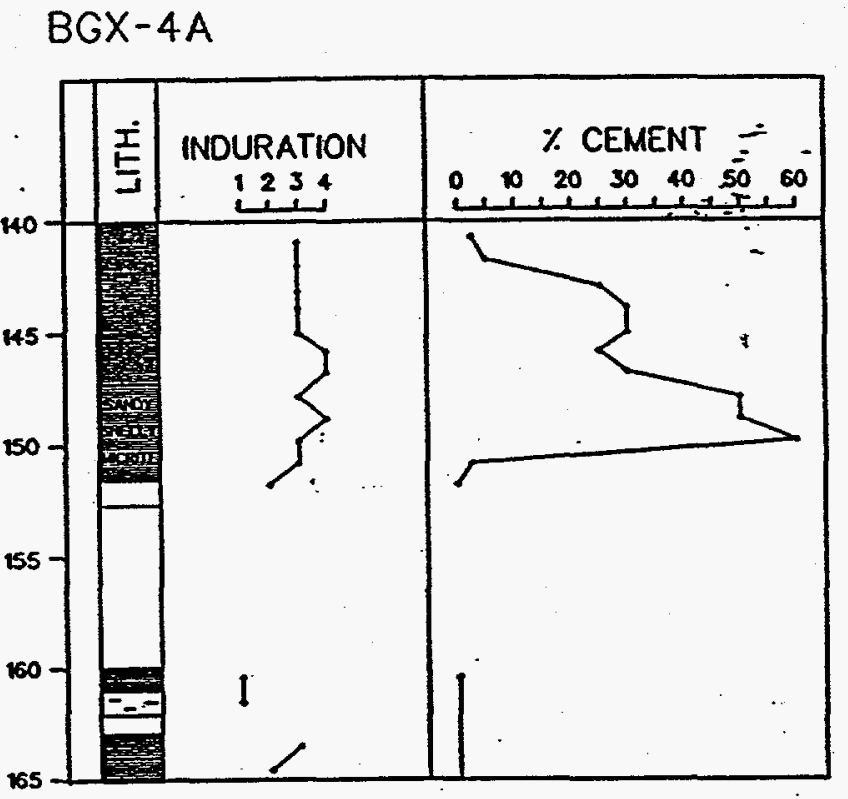




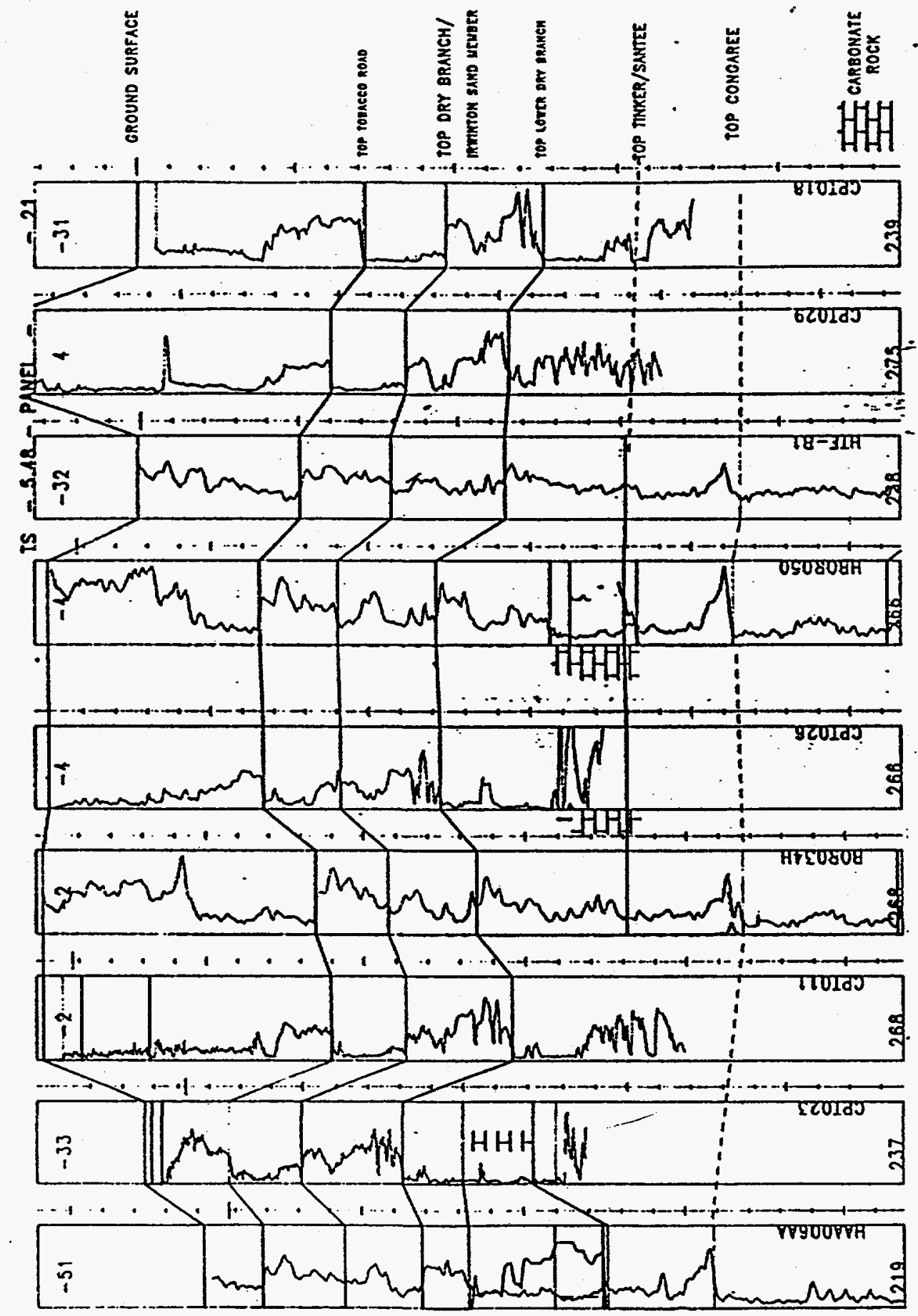




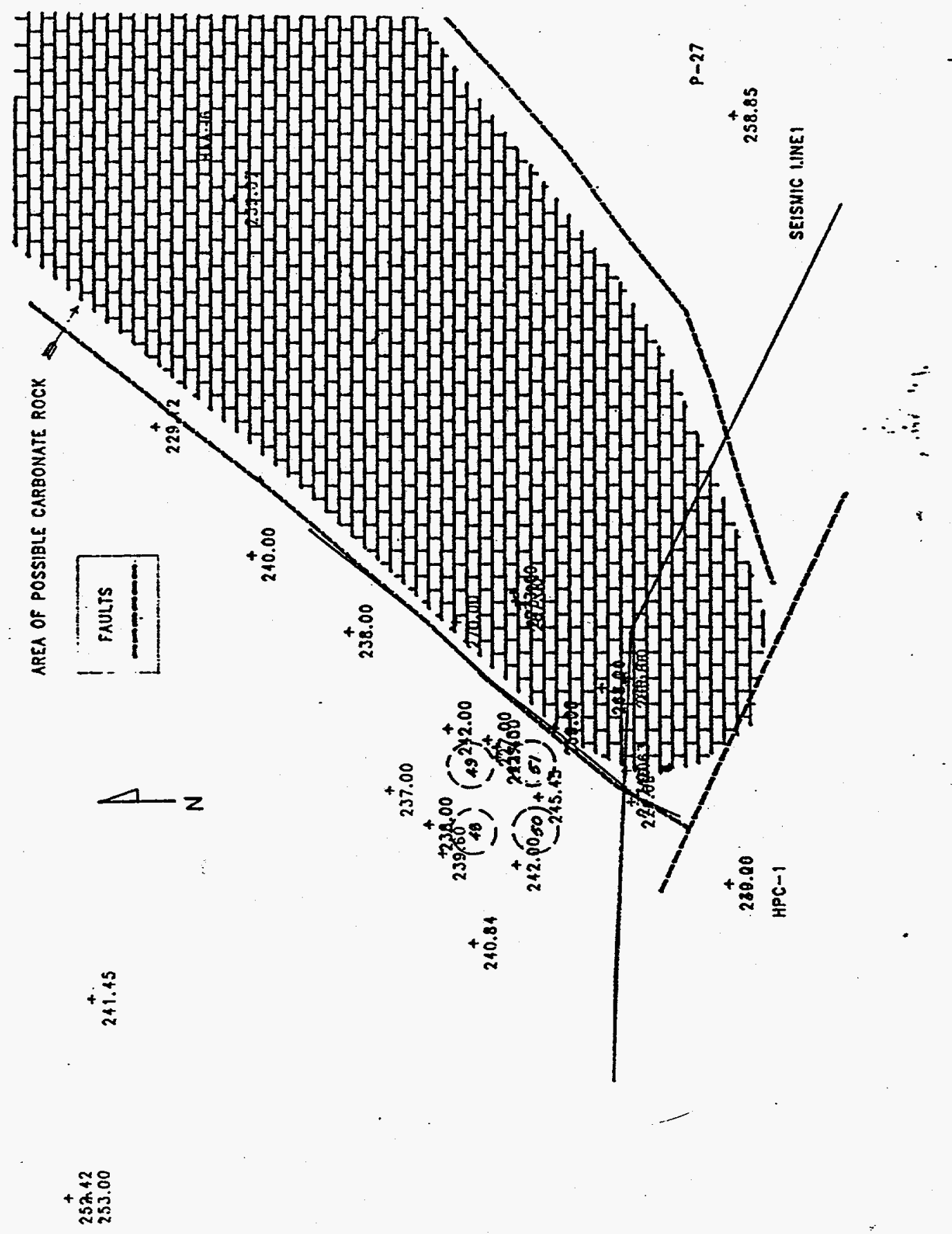




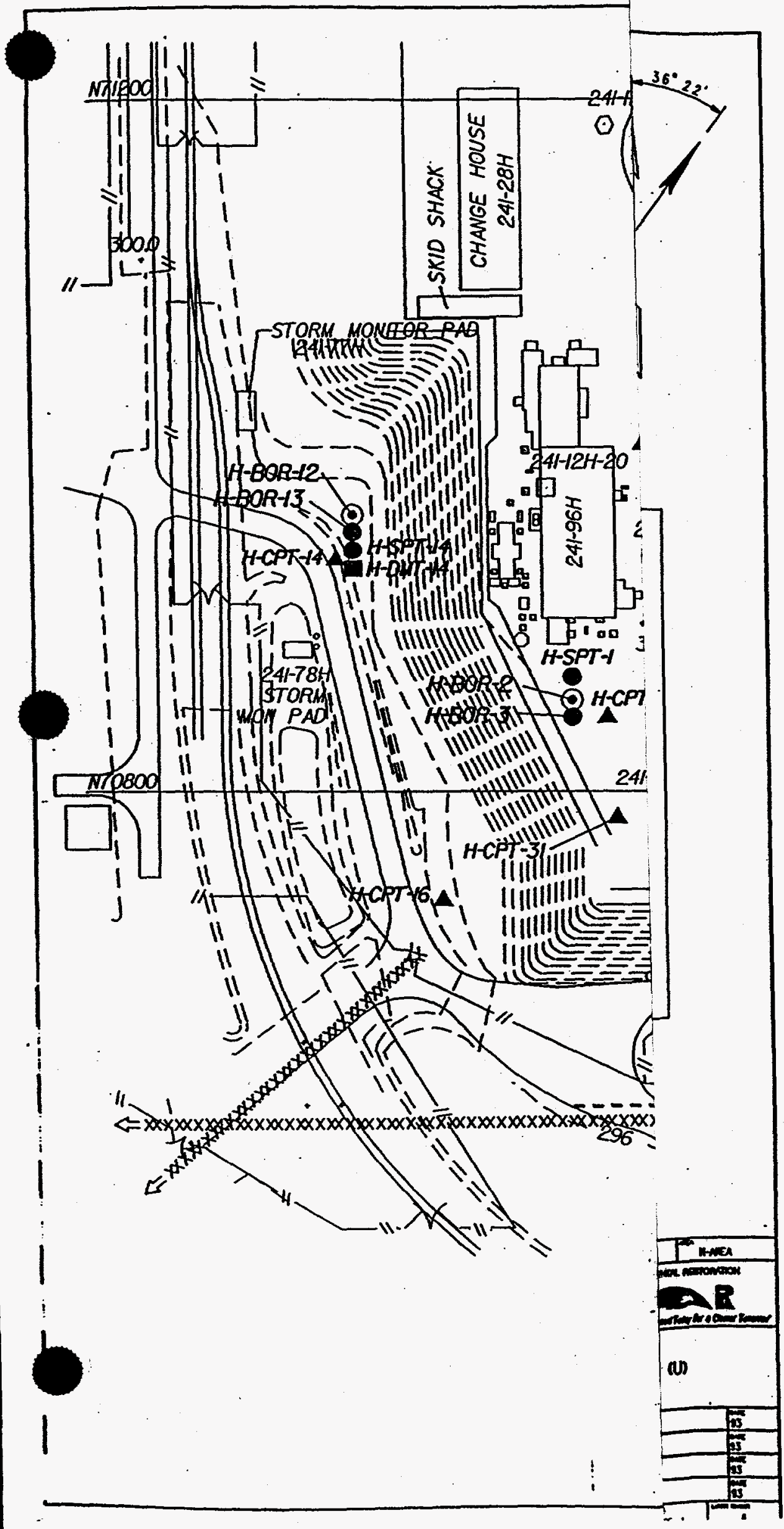

Figure 3-1 Boring Exploration Plan 


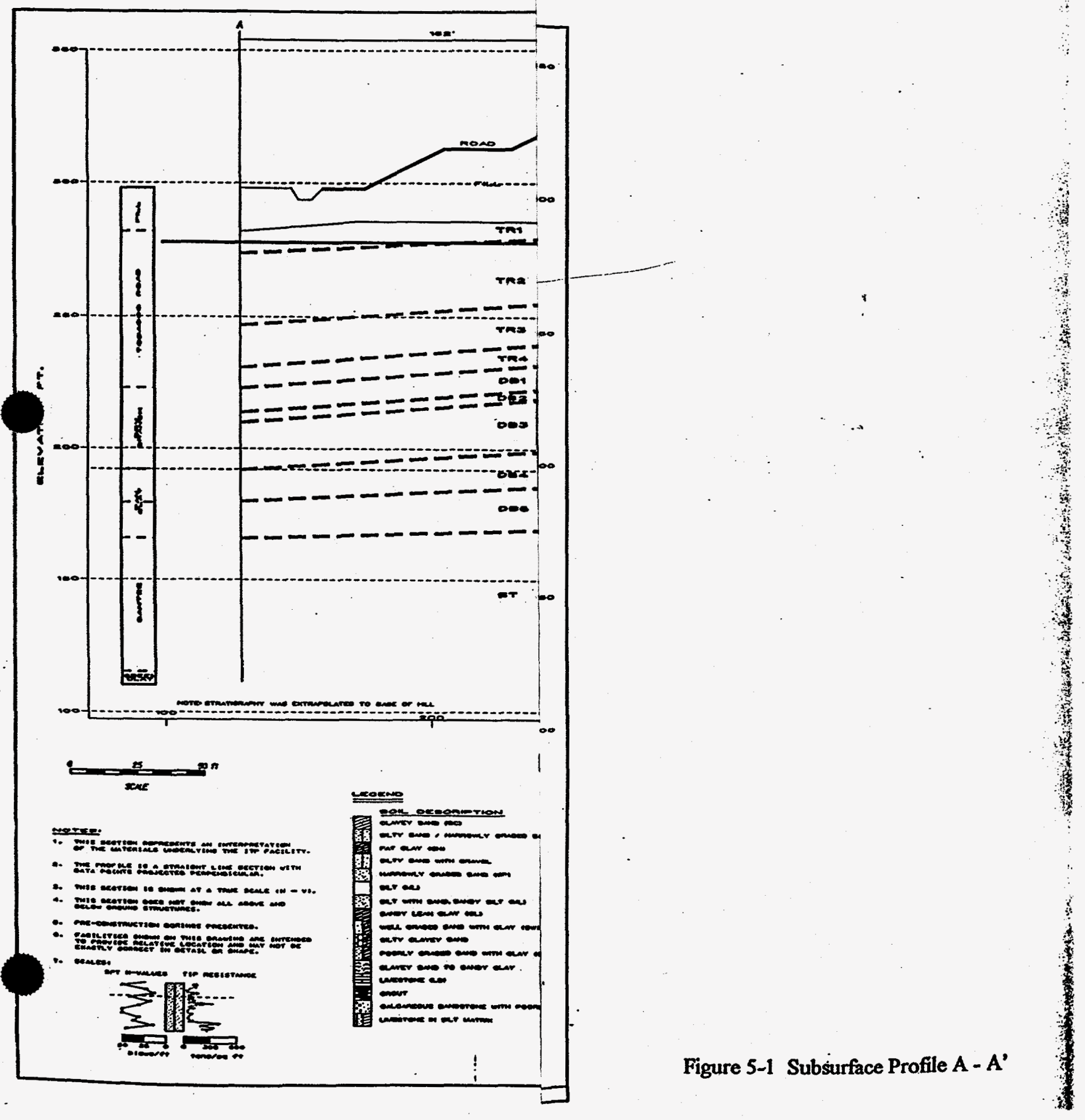


- Site Geocechnical Services

In Tank Processing (ITP) Geotectunical Summary Report

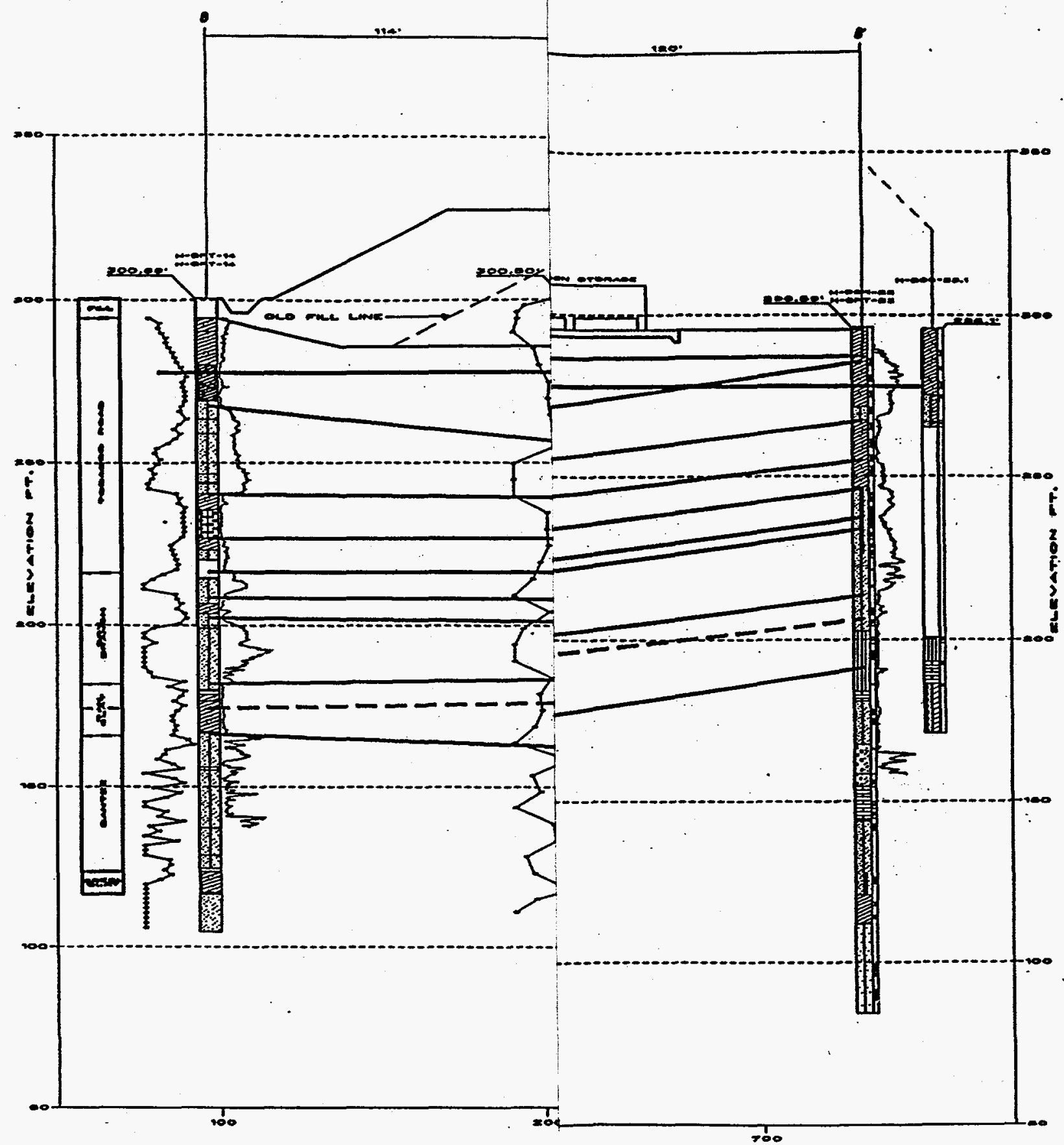

serrin:

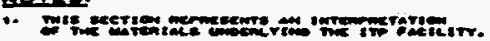

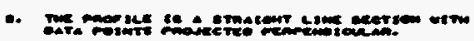

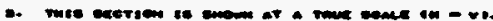

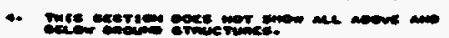

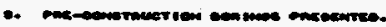

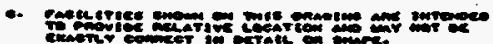

1. cerese.
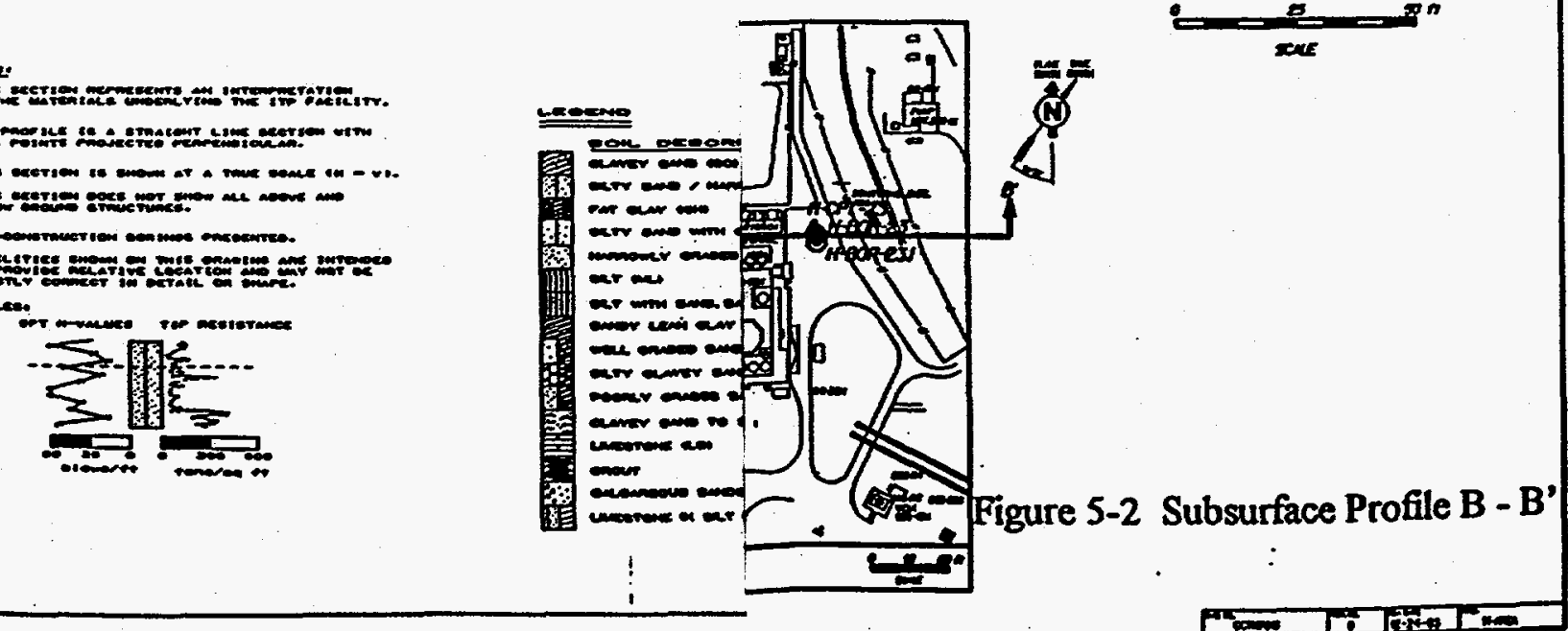


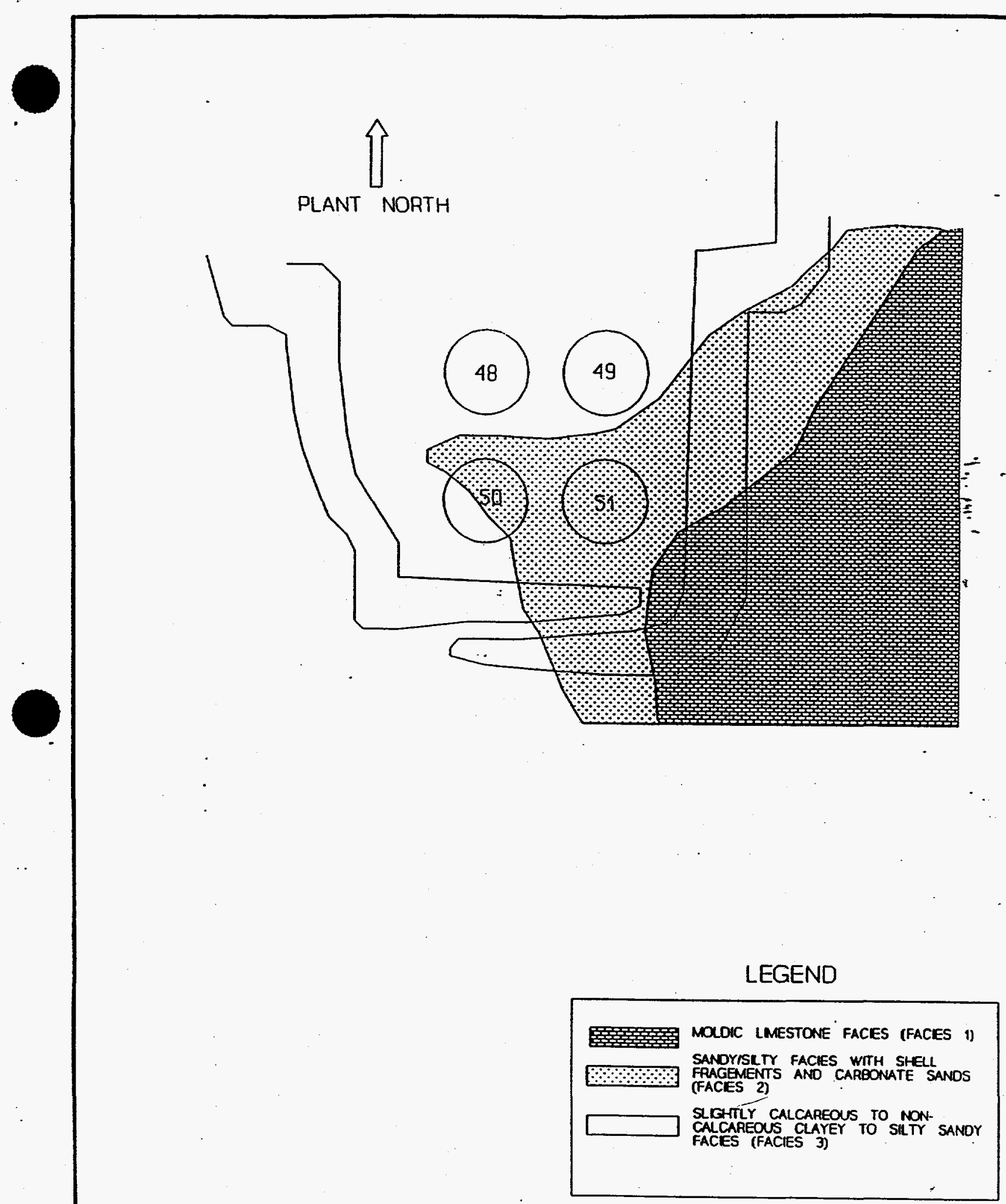

\section{SCALE}

1 in. $=160 \mathrm{ft}$.

Figure 5-3 Idealized Facies Map of the Upper Santee Formation 


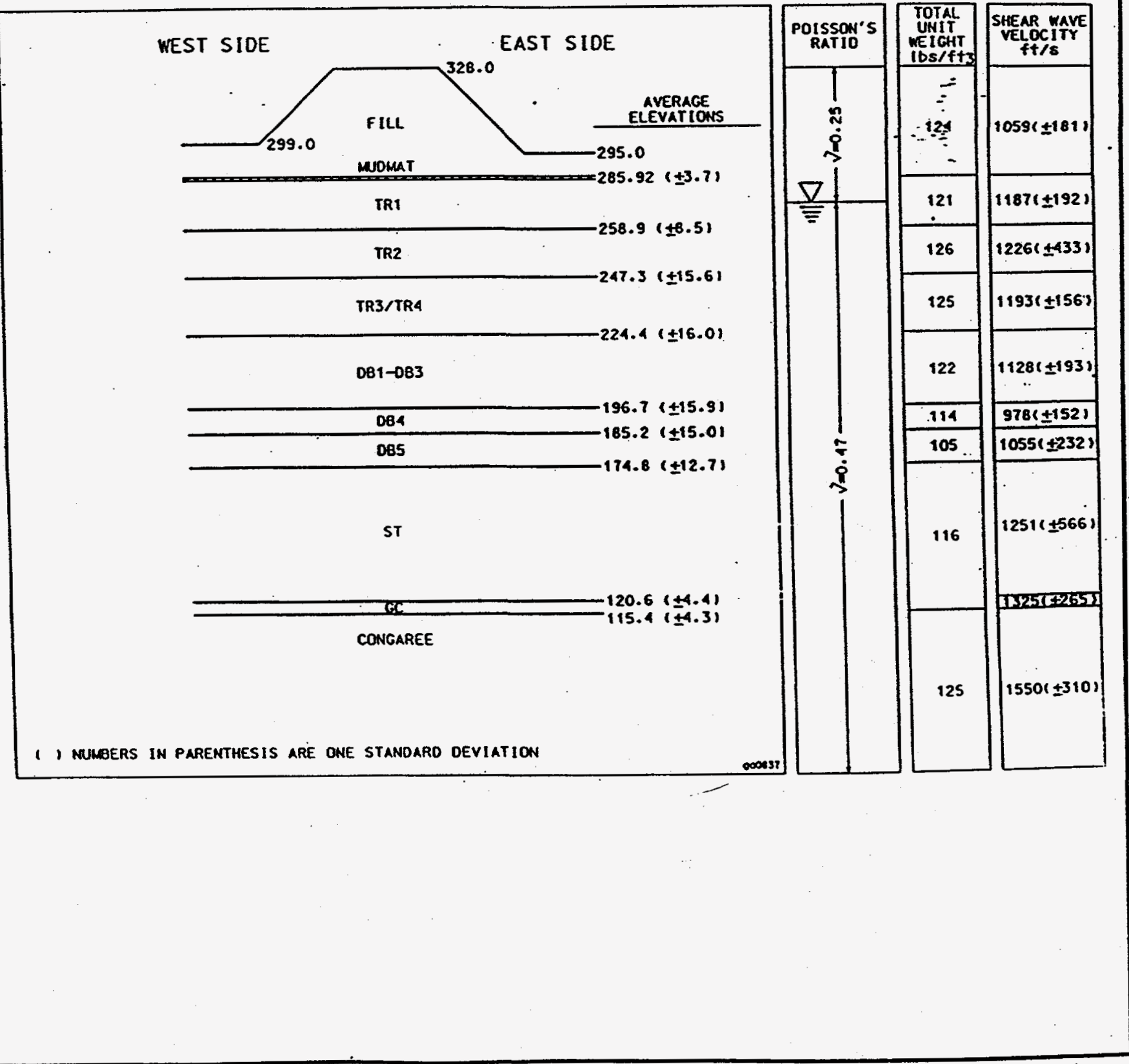

Figure 6-1 Idealized Cross Section Showing Mean Shear Wave Velocities, Poisson's Ratios, and Unit Weights for Each Formation. 


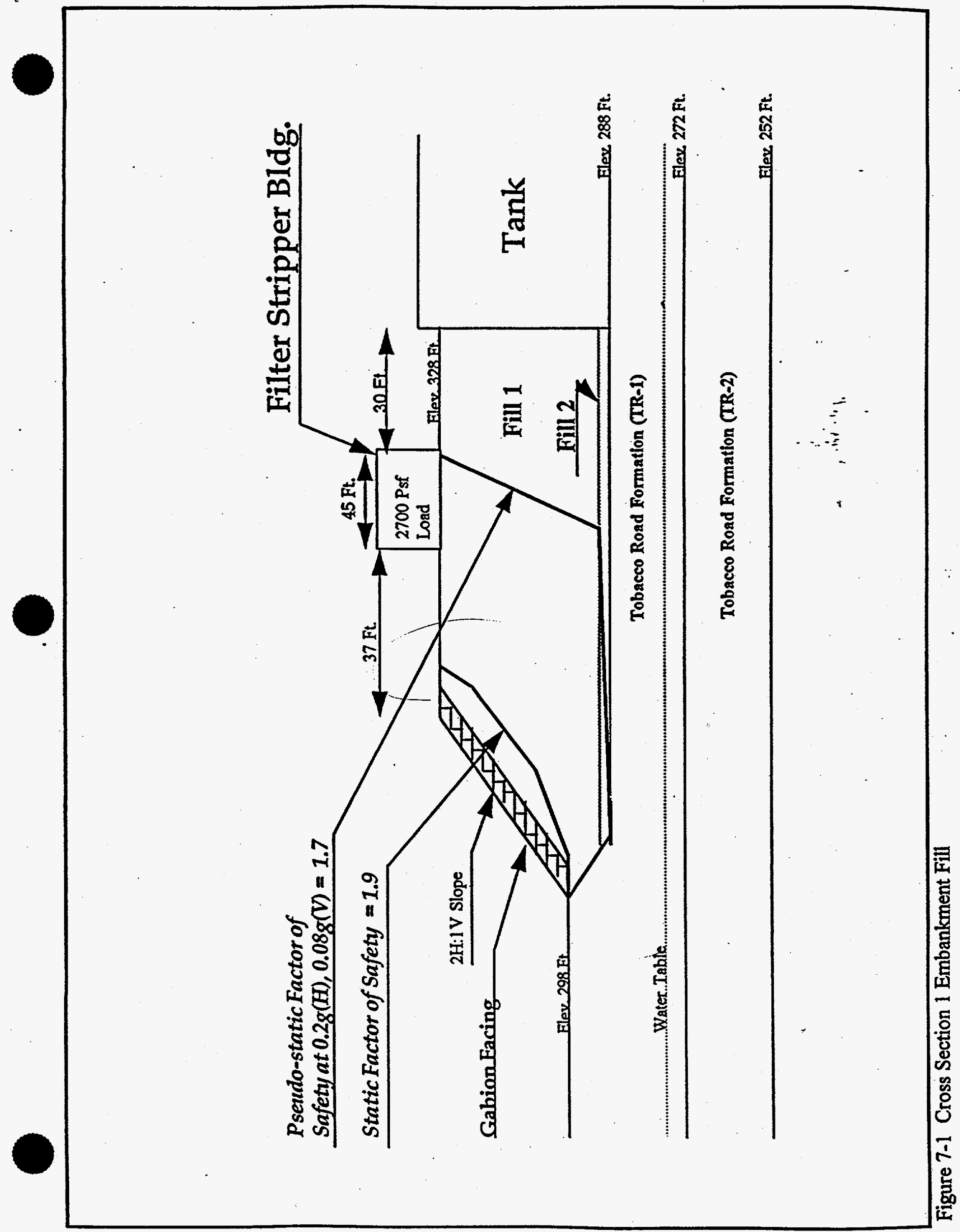




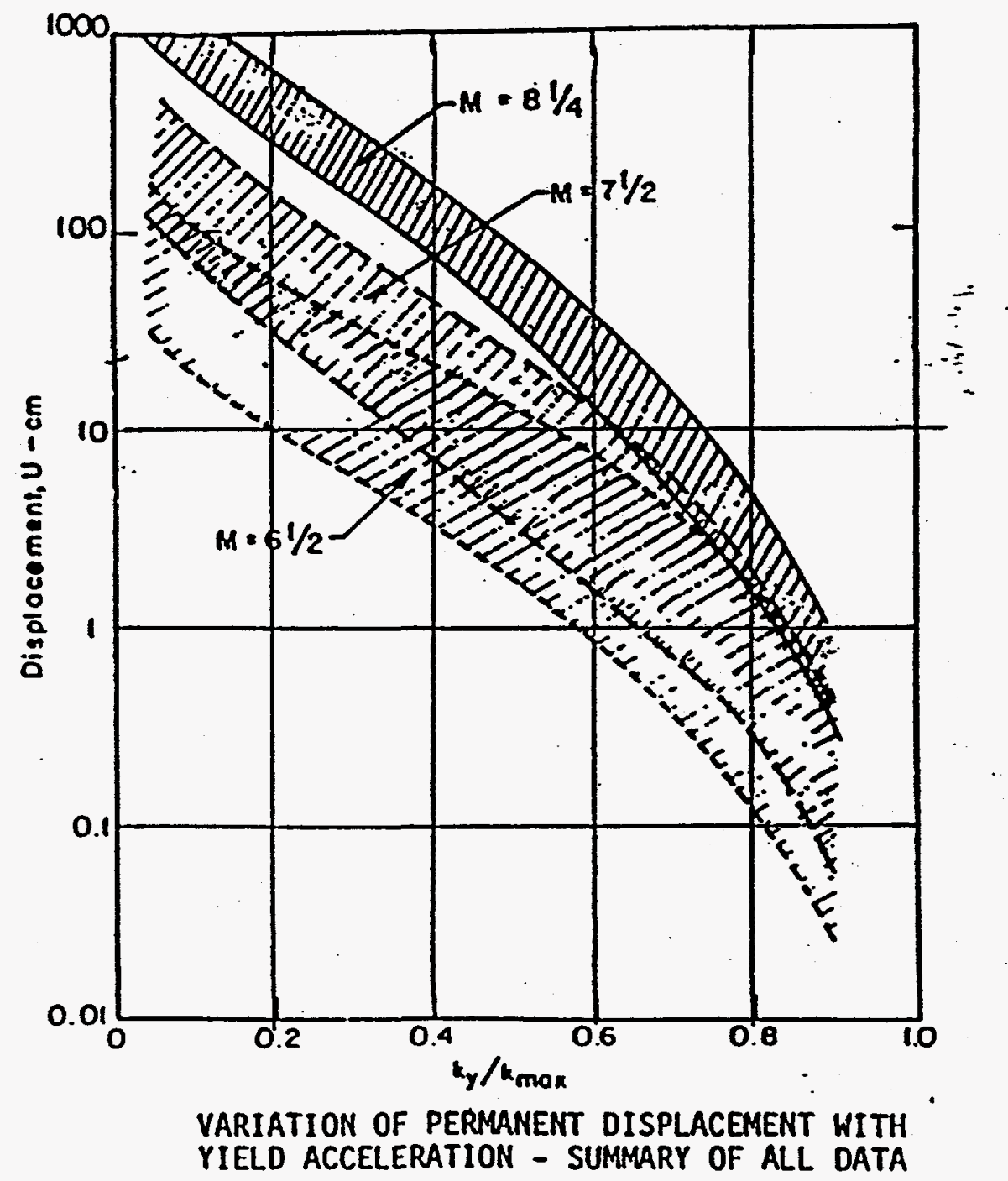

Reference: Makdisi and Seed, (1977)

Figure 7-2 Variation of Permanent Displacement with Yield Acceleration 


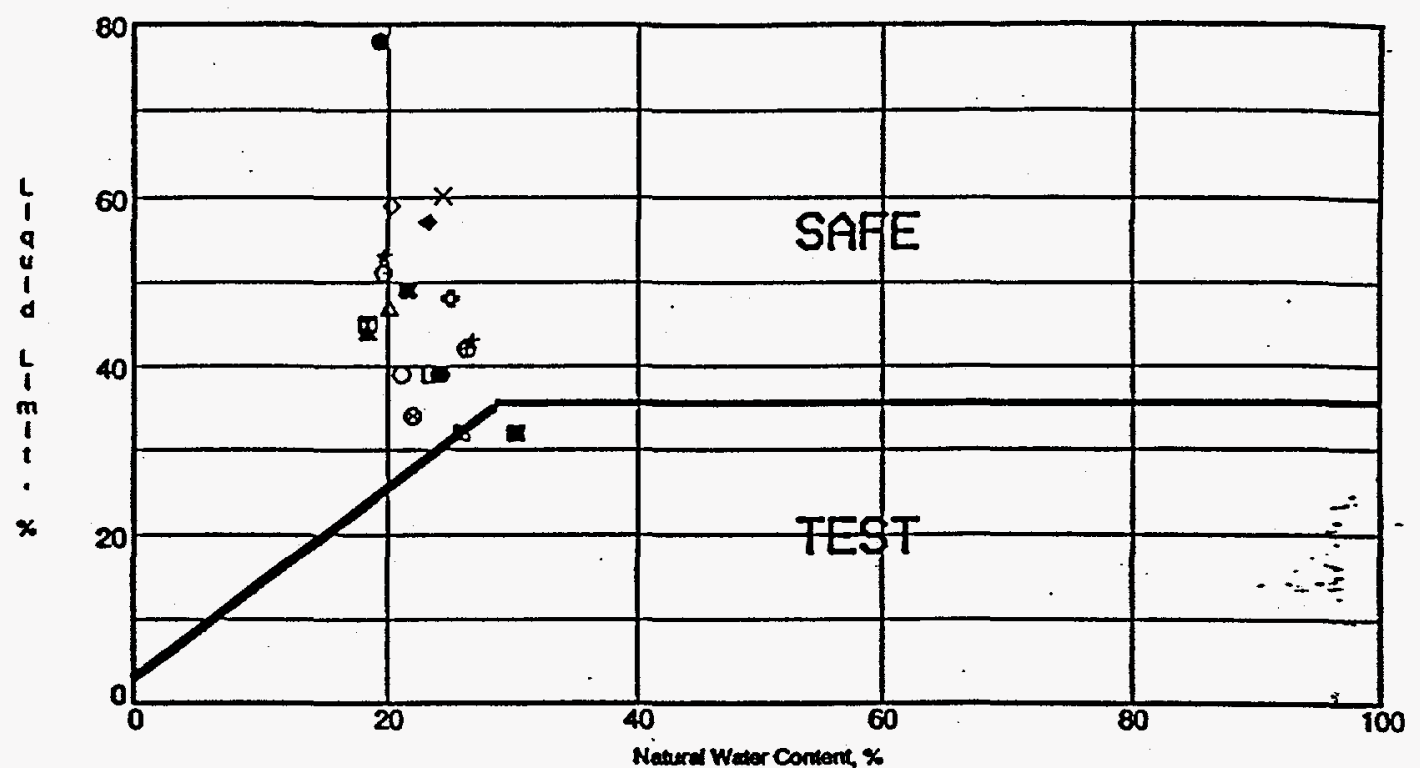

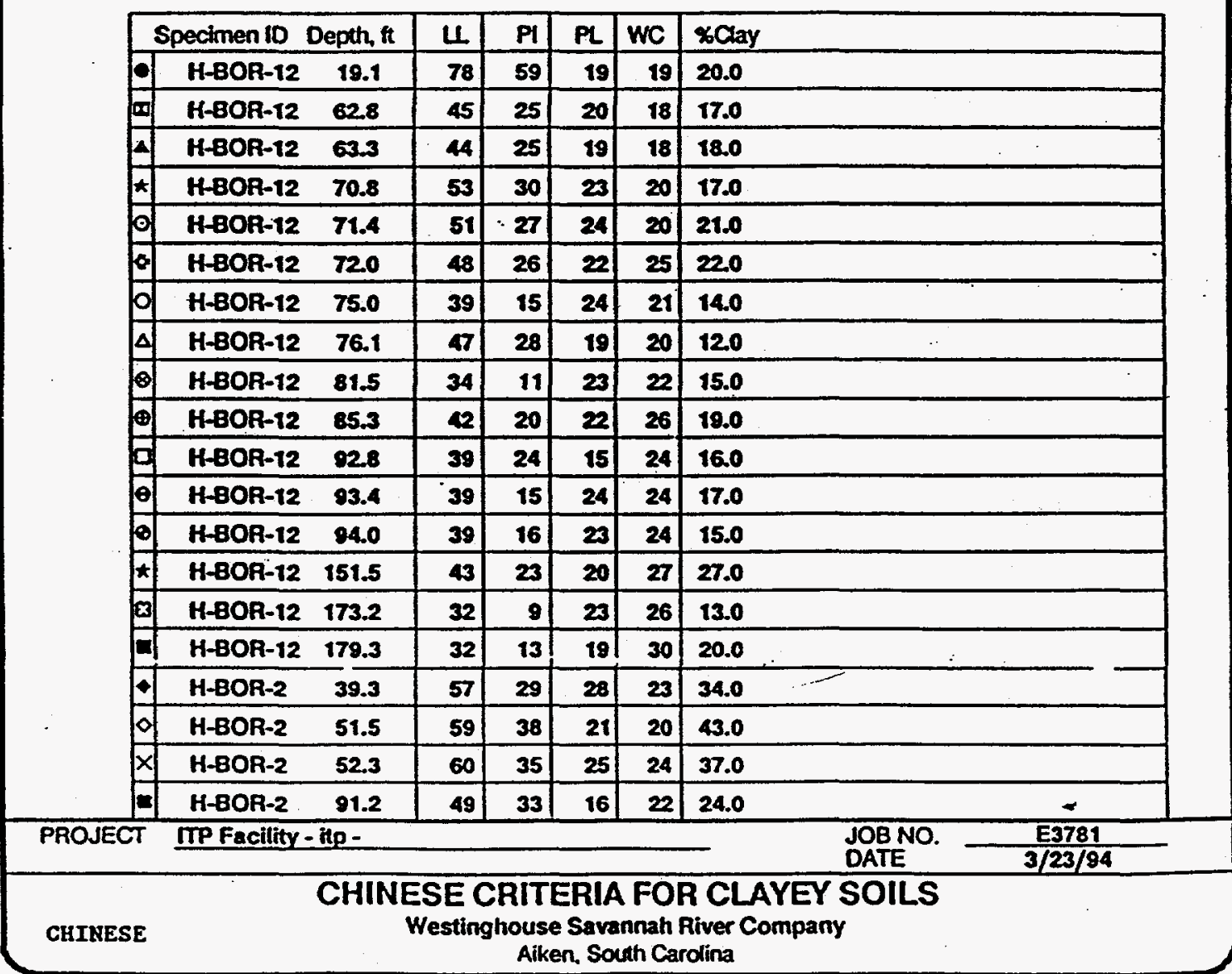

Figure 7-3a Chinese Criteria for Clayey Soils 


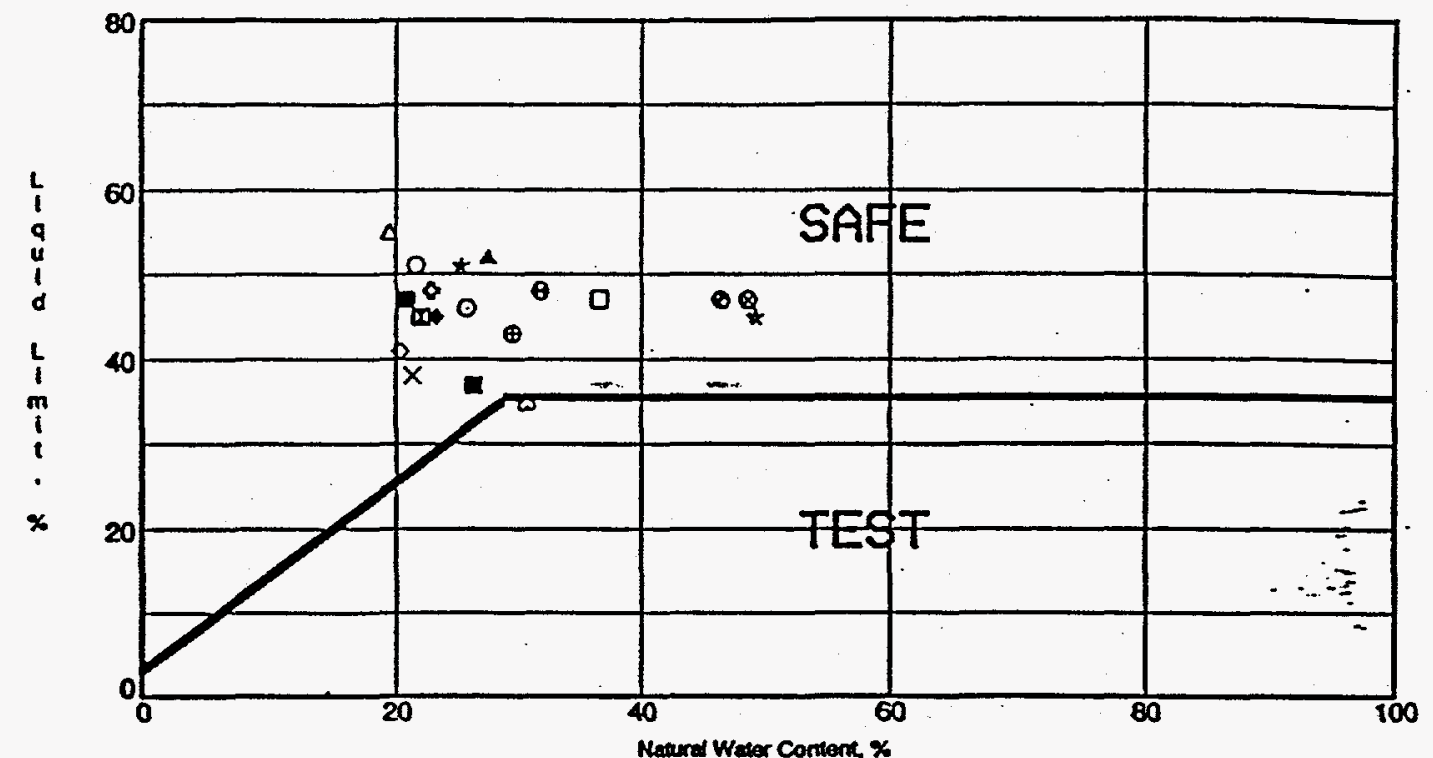

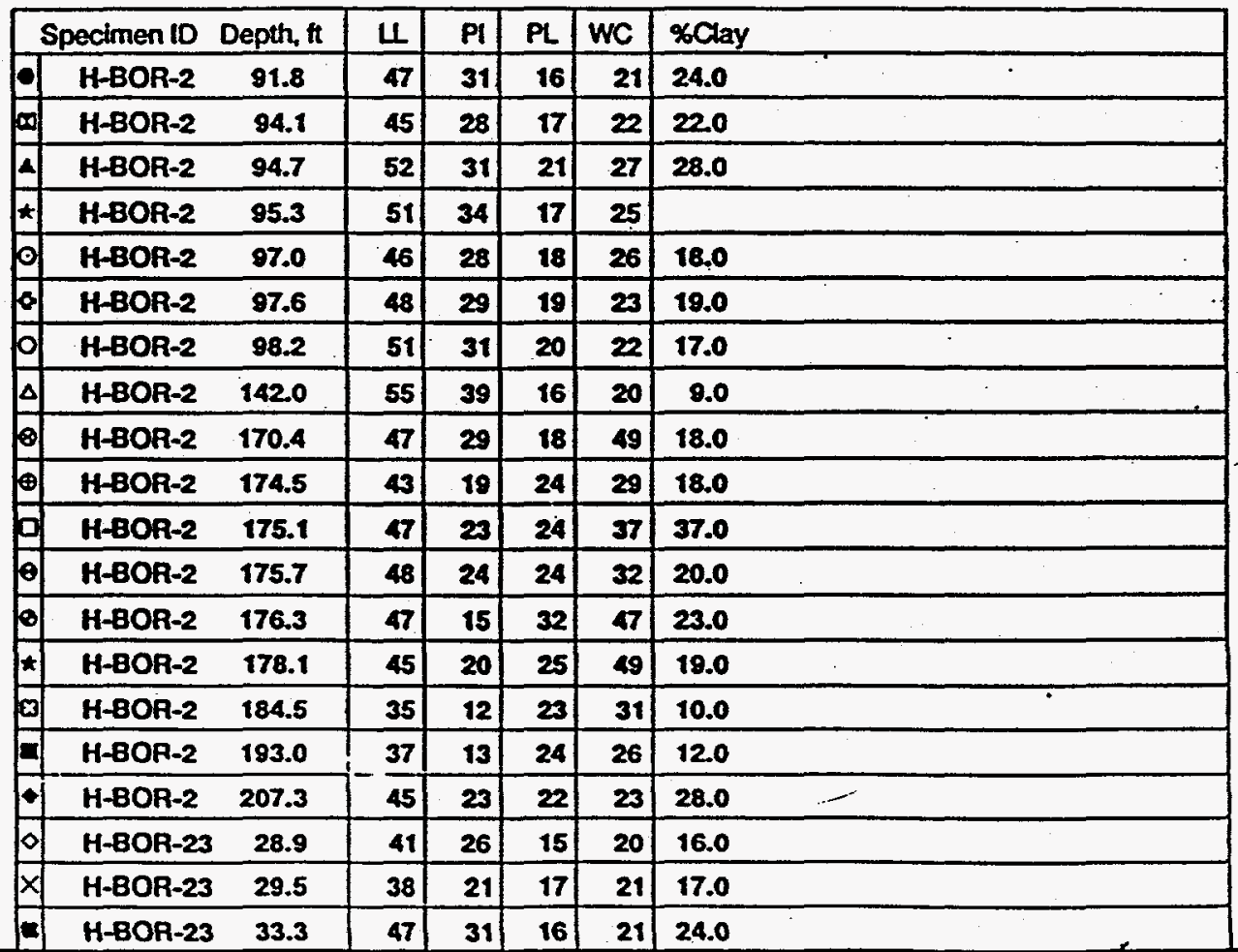

PROJECT ITP Facility - itp -

JOBNO. E3781 $3 / 23 / 94$

CHINESE CRITERIA FOR CLAYEY SOILS Westinghouse Savannah River Company Aiken. South Carolina

Figure 7-3b Chinese Criteria for Clayey Soils 


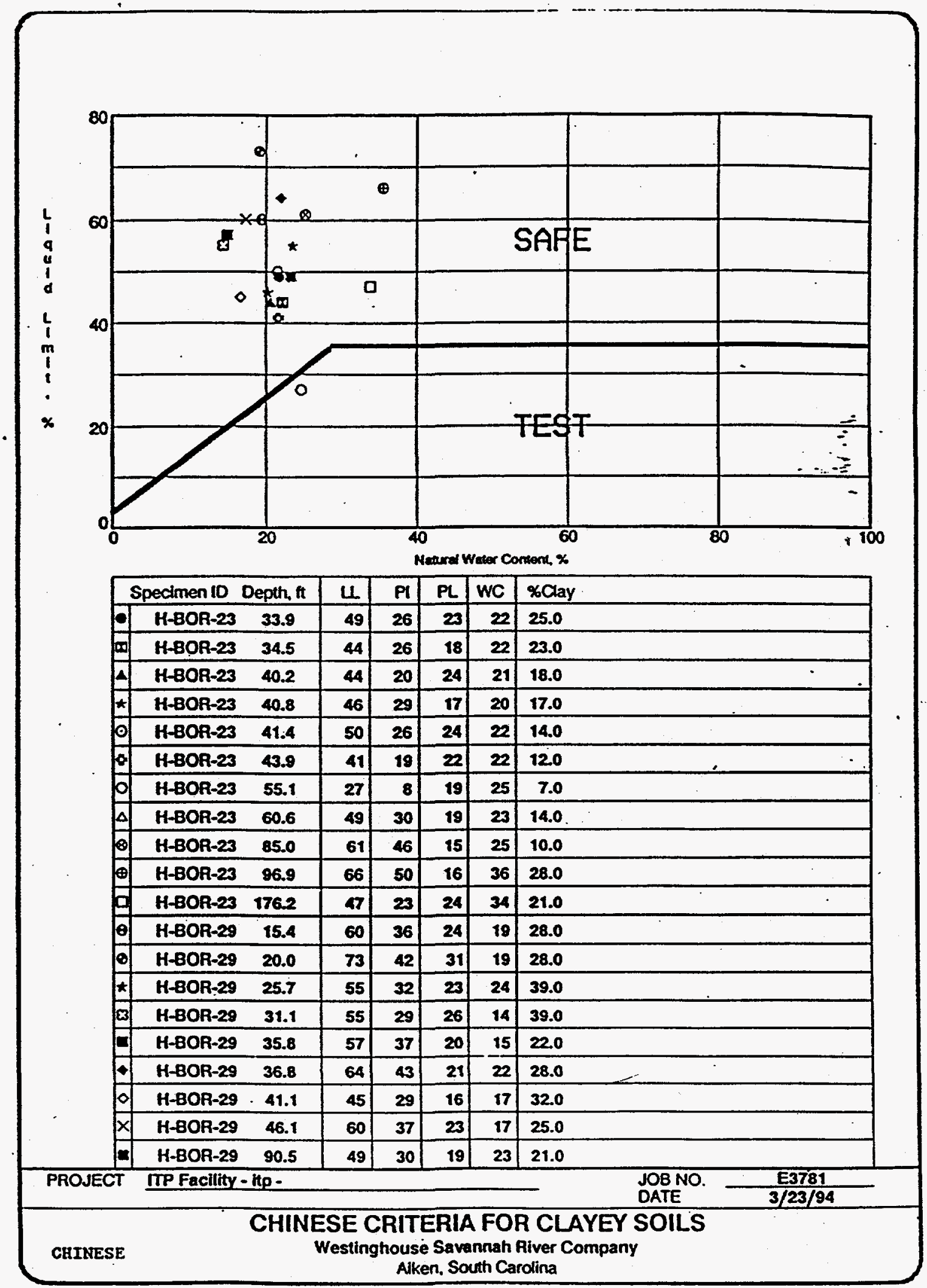

Figure 7-3c Chinese Criteria for Clayey Soils 


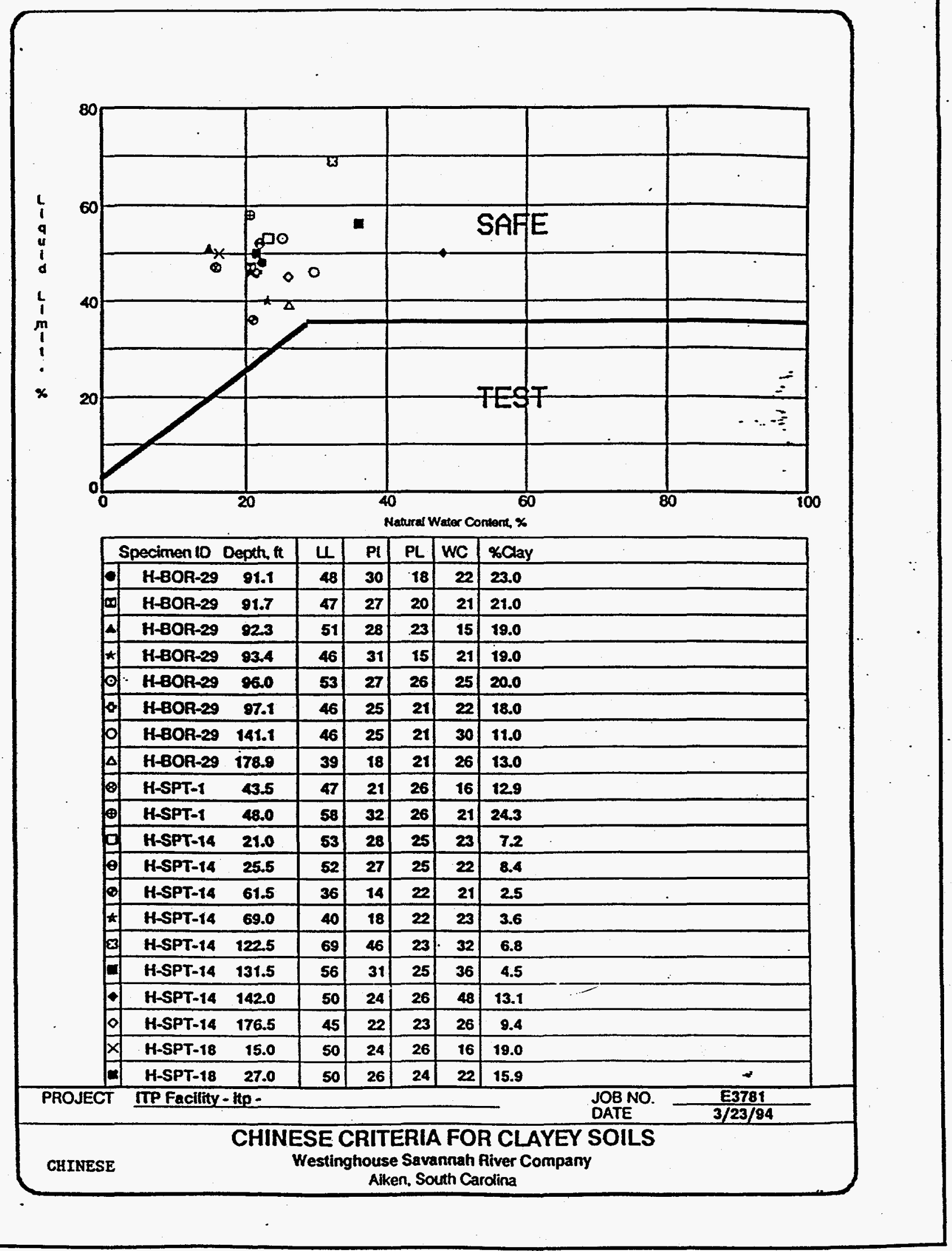

Figure 7-3d Chinese Criteria for Clayey Soils 


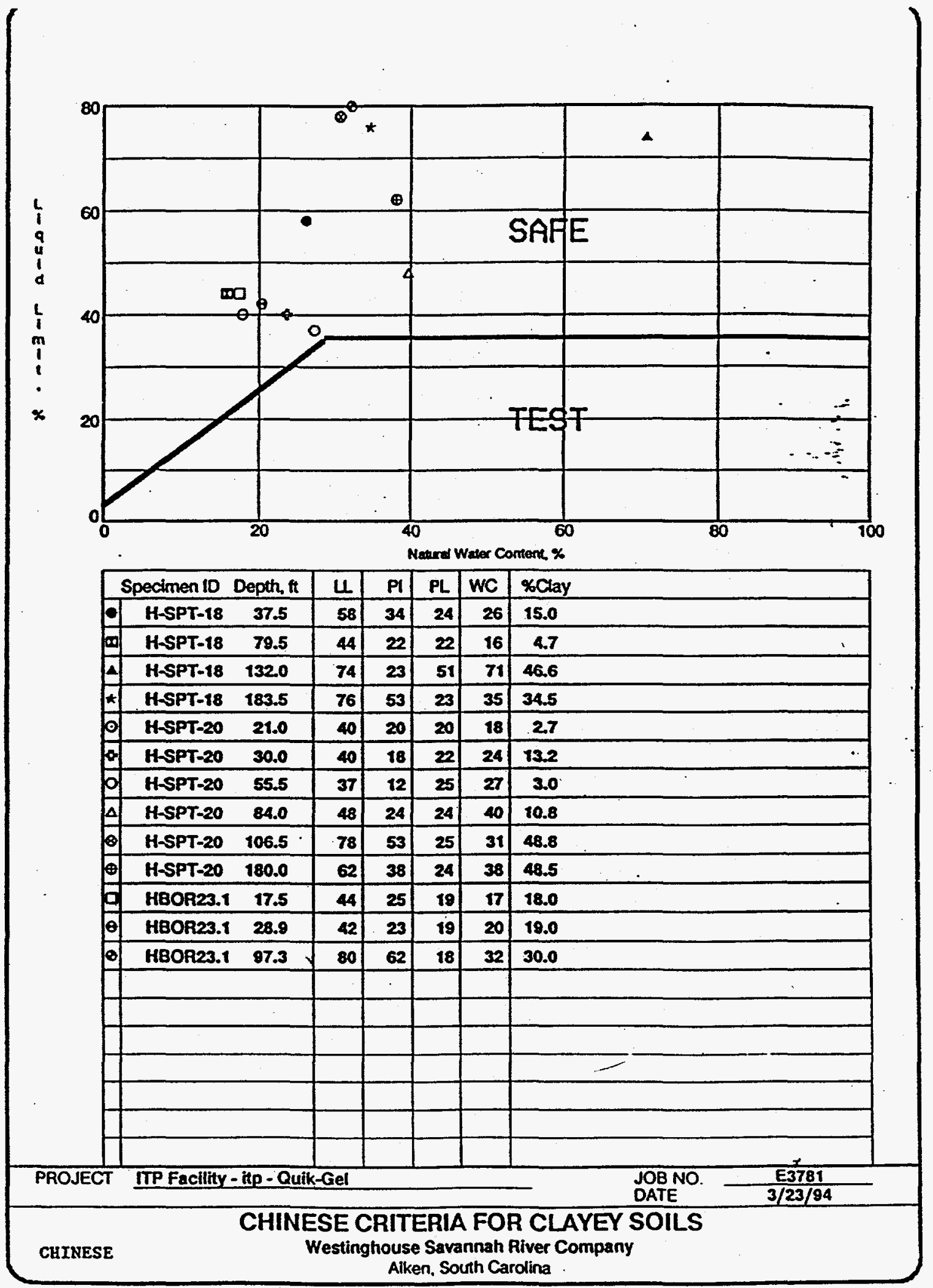

Figure 7-3e Chinese Criteria for Clayey Soils 


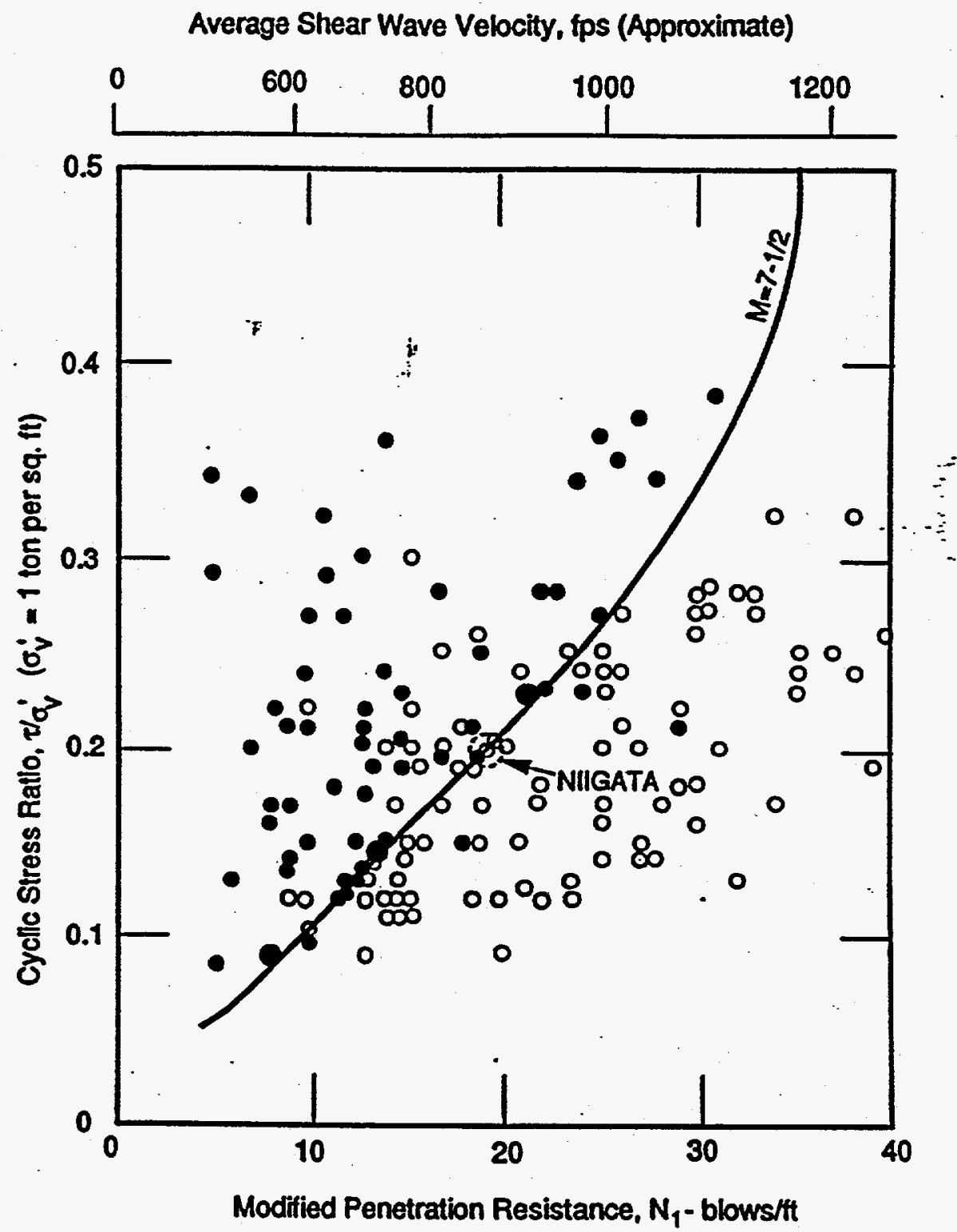

\section{LEGEND}

- Limits set by Chinese Code (1974)

- Liquefaction

- No Liquefaction

Reference: Seed, Idriss, and Arango, (1983)

Figure 7-4 Cyclic Stress Ratio versus Modified SPT N Value $\left(\mathbb{N}_{l}\right)$ 


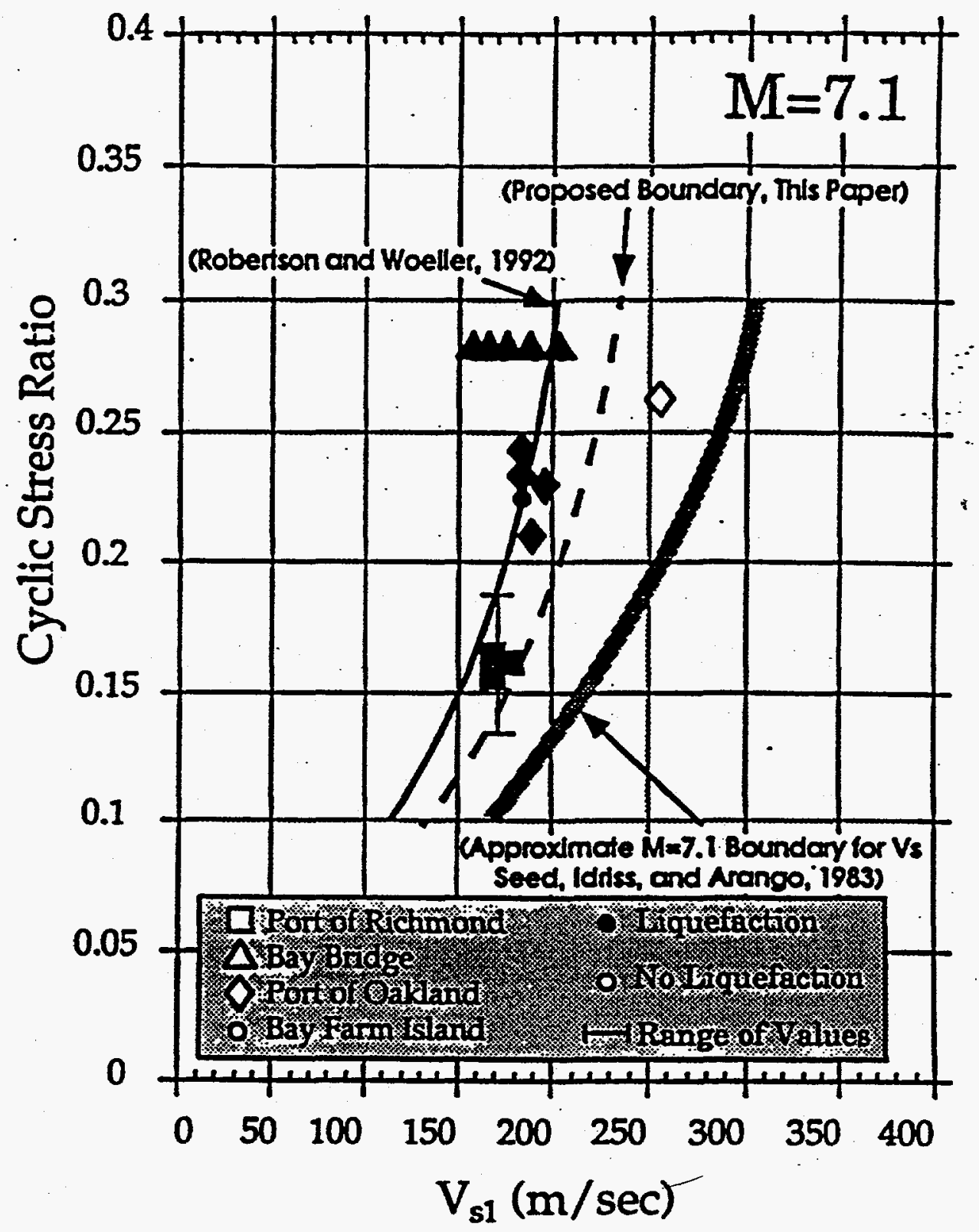

Reference: Kayen et al,, (1992)

Figure 7-5 Cyclic Stress Ratio versus Shear Wave Velocity 


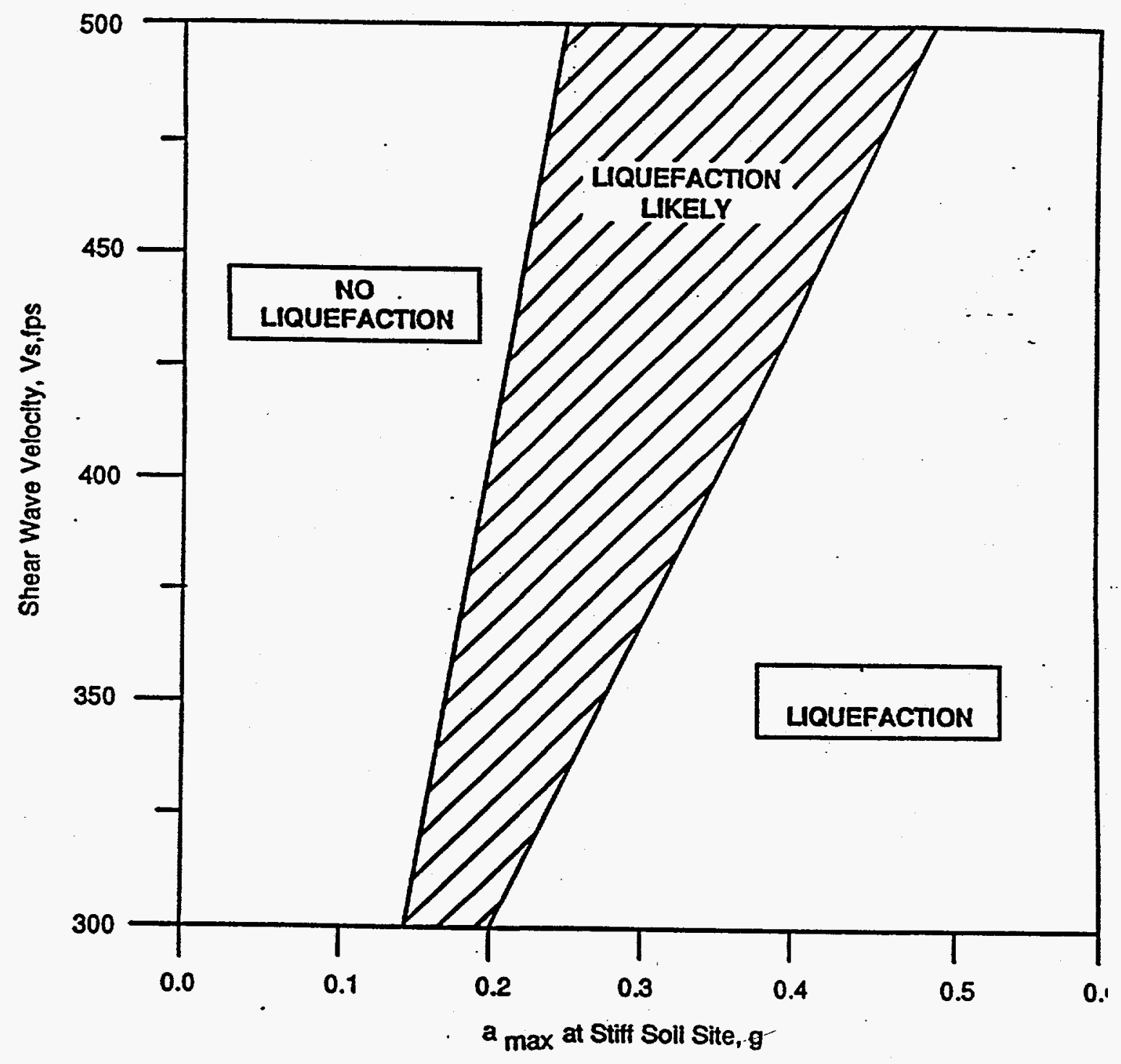

Reference: Stokoe et al, (1988)

Figure 7-6 Shear Wave Velocity versus Maximum Acceleration 


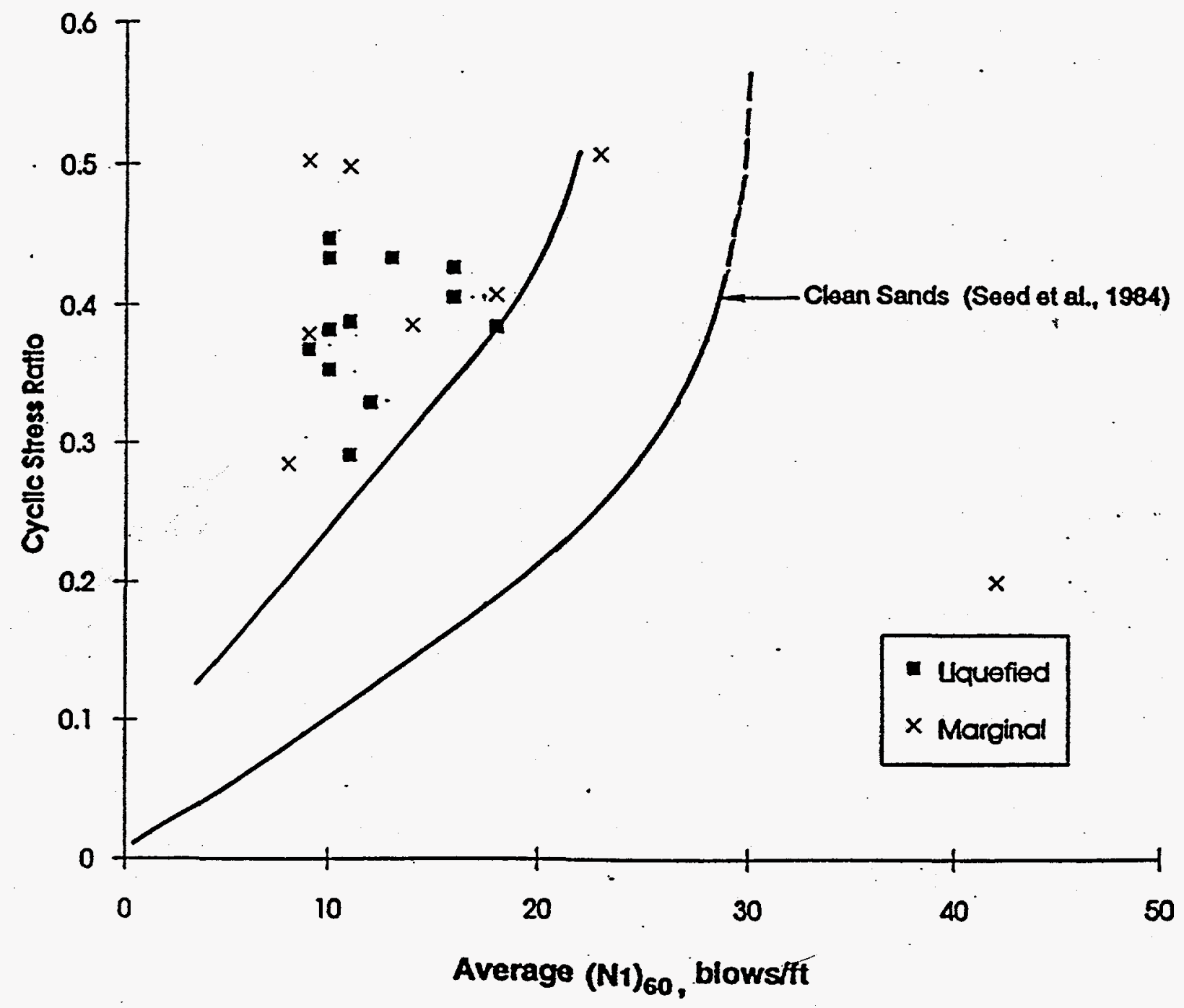

Reference: Arango, Lewis, and Kimball, (1994)

Figure 7-7 Charleston Earthquake: Liquefaction / Marginal Liquefaction Data 


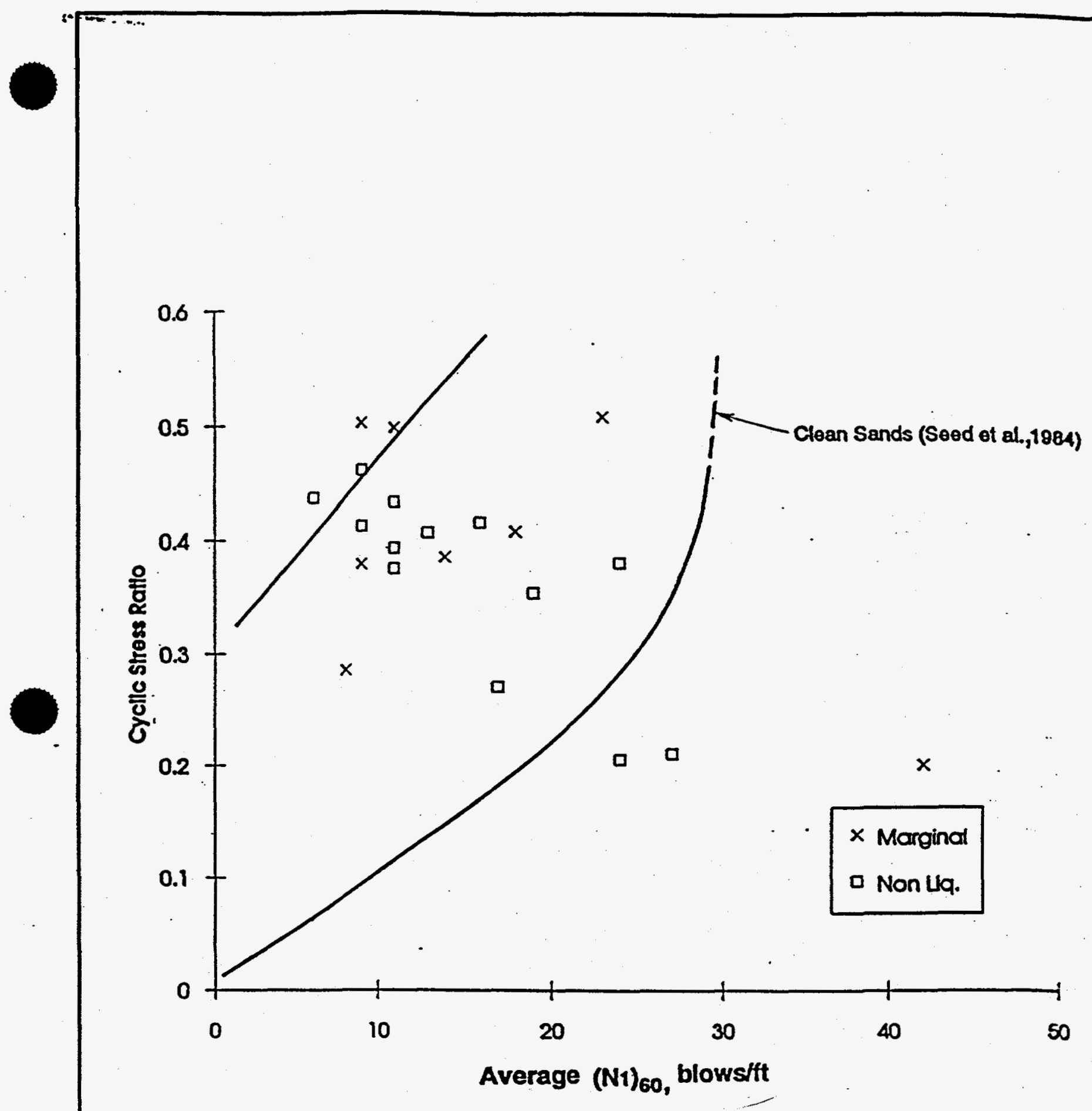

Reference: Arango, Lewis, and Kimball, (1994)

Figure 7-8 Charleston Earthquake: No Liquefaction / Marginal Liquefaction Data 


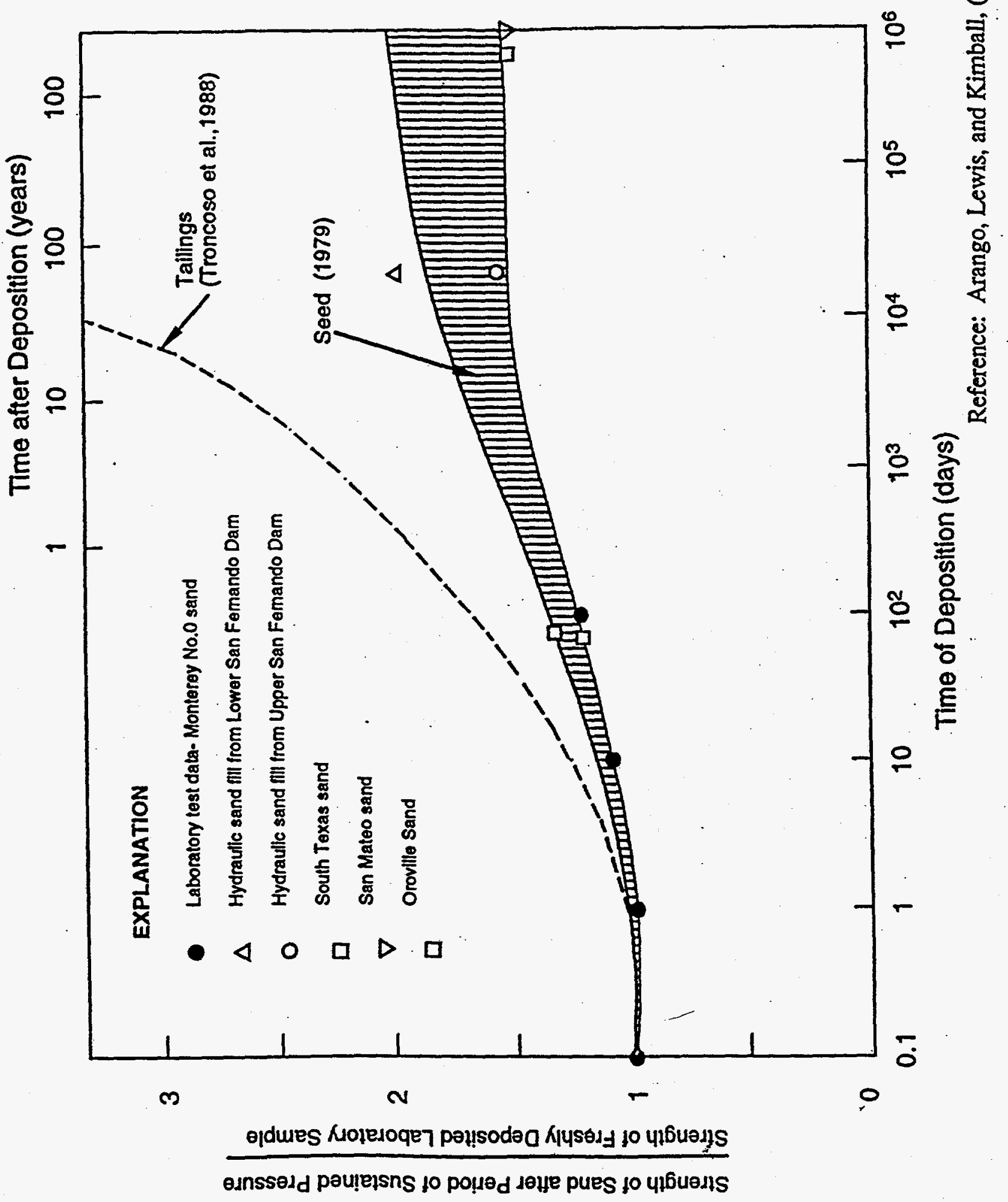




\section{Strength of Sand after T vears}

Strength Based on Empirical Chart (Clean Sands)

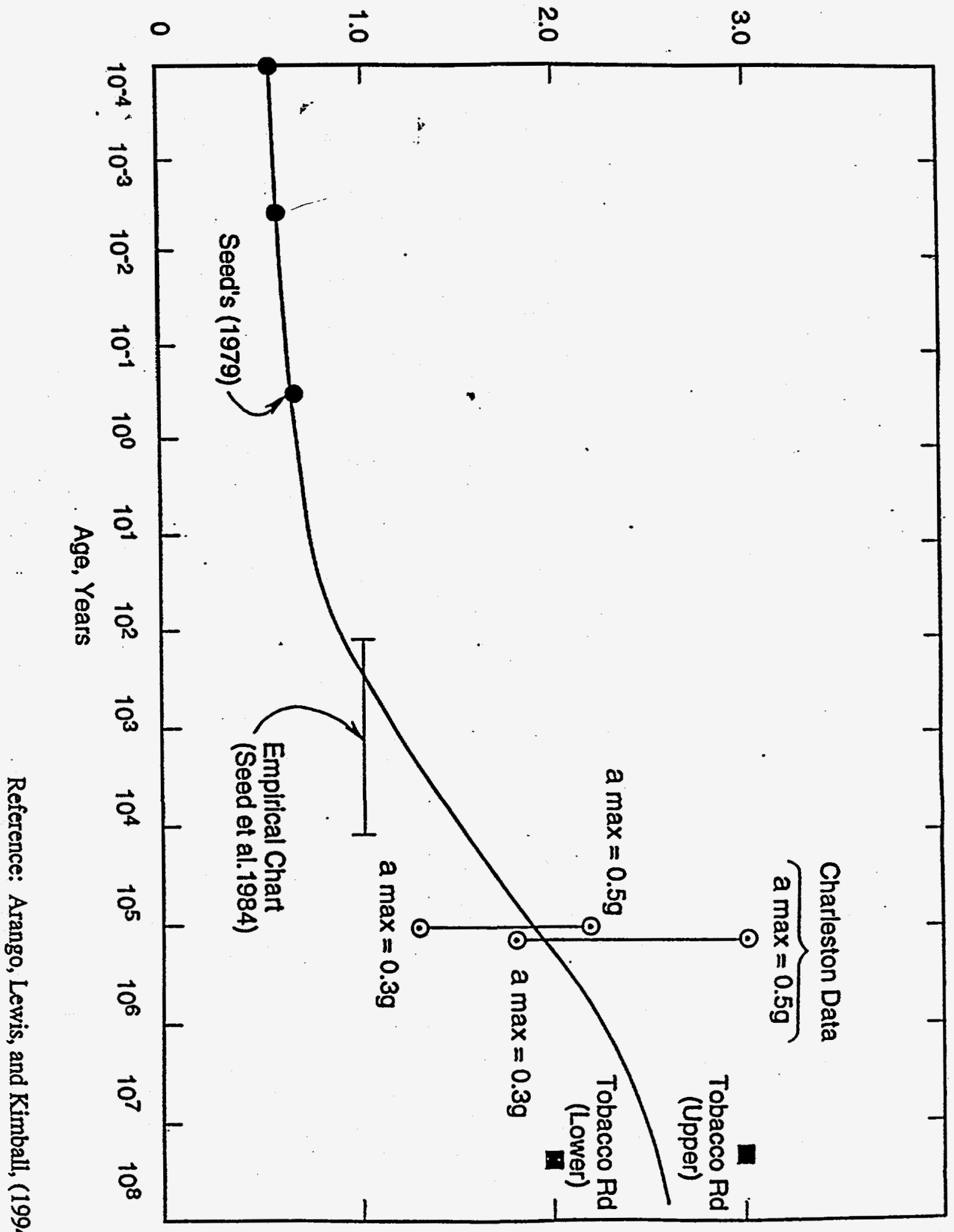




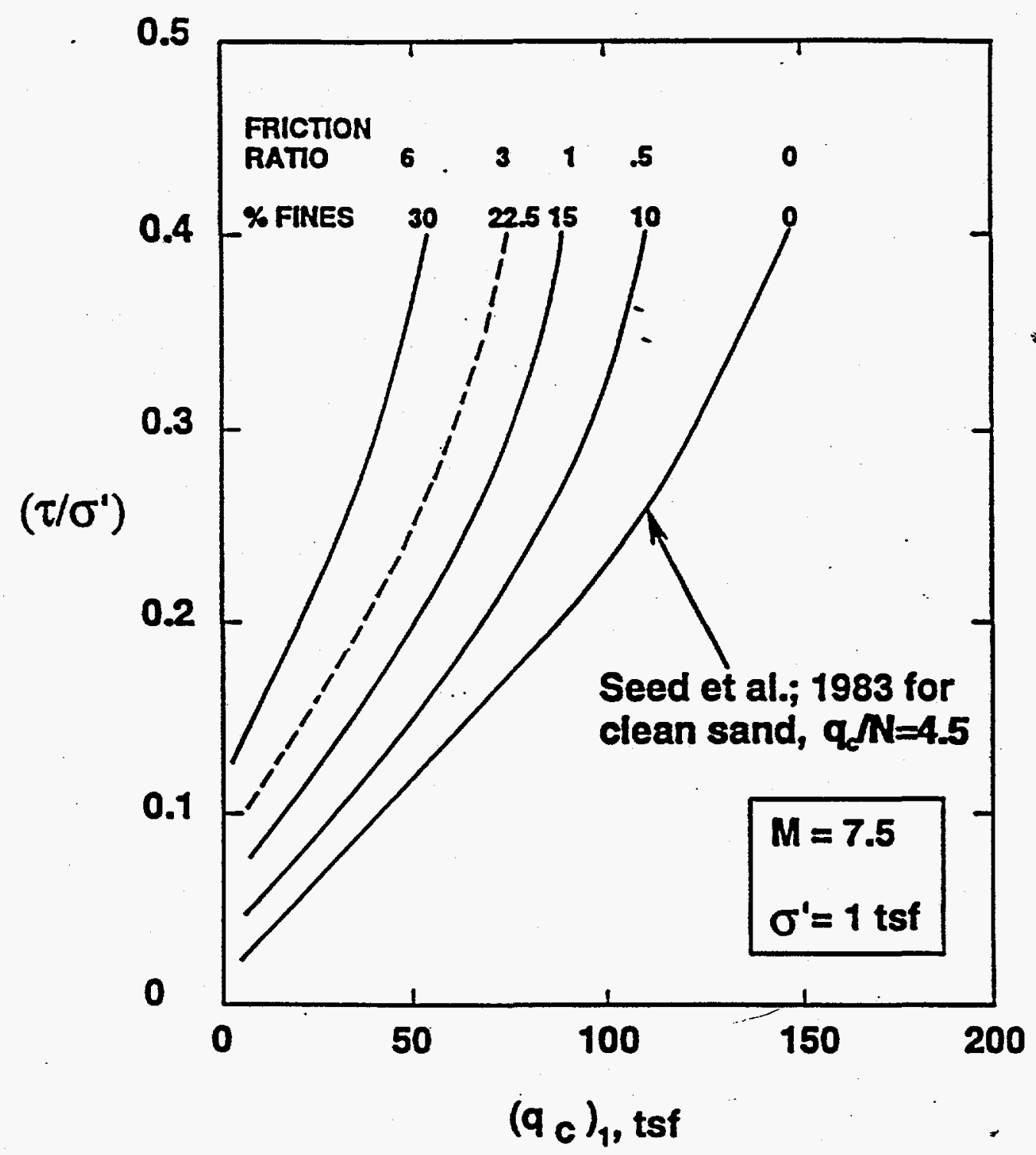

Figure 7-11 Cyclic Stress Ratio versus Cone Penetration Tip Resistance 


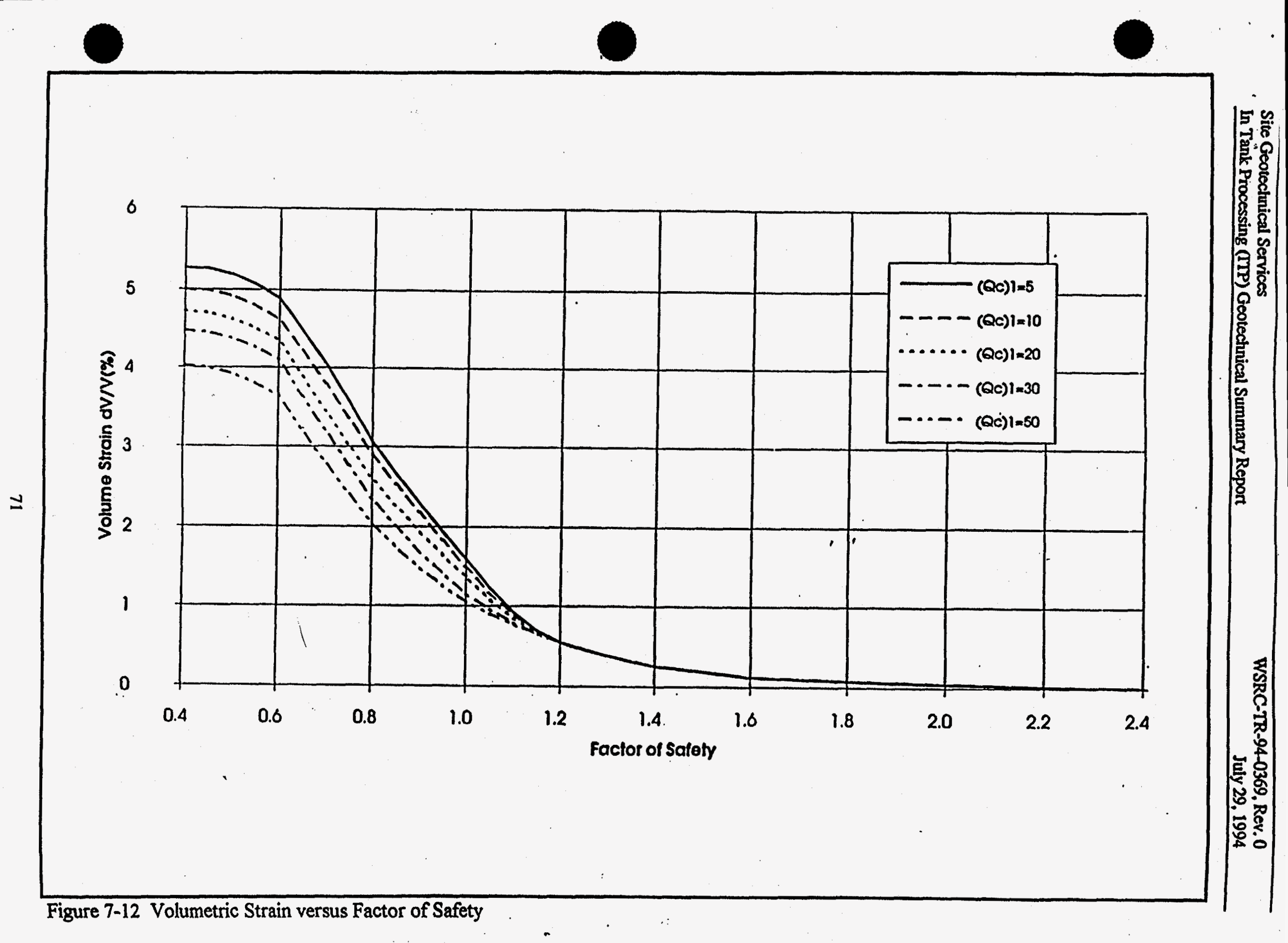




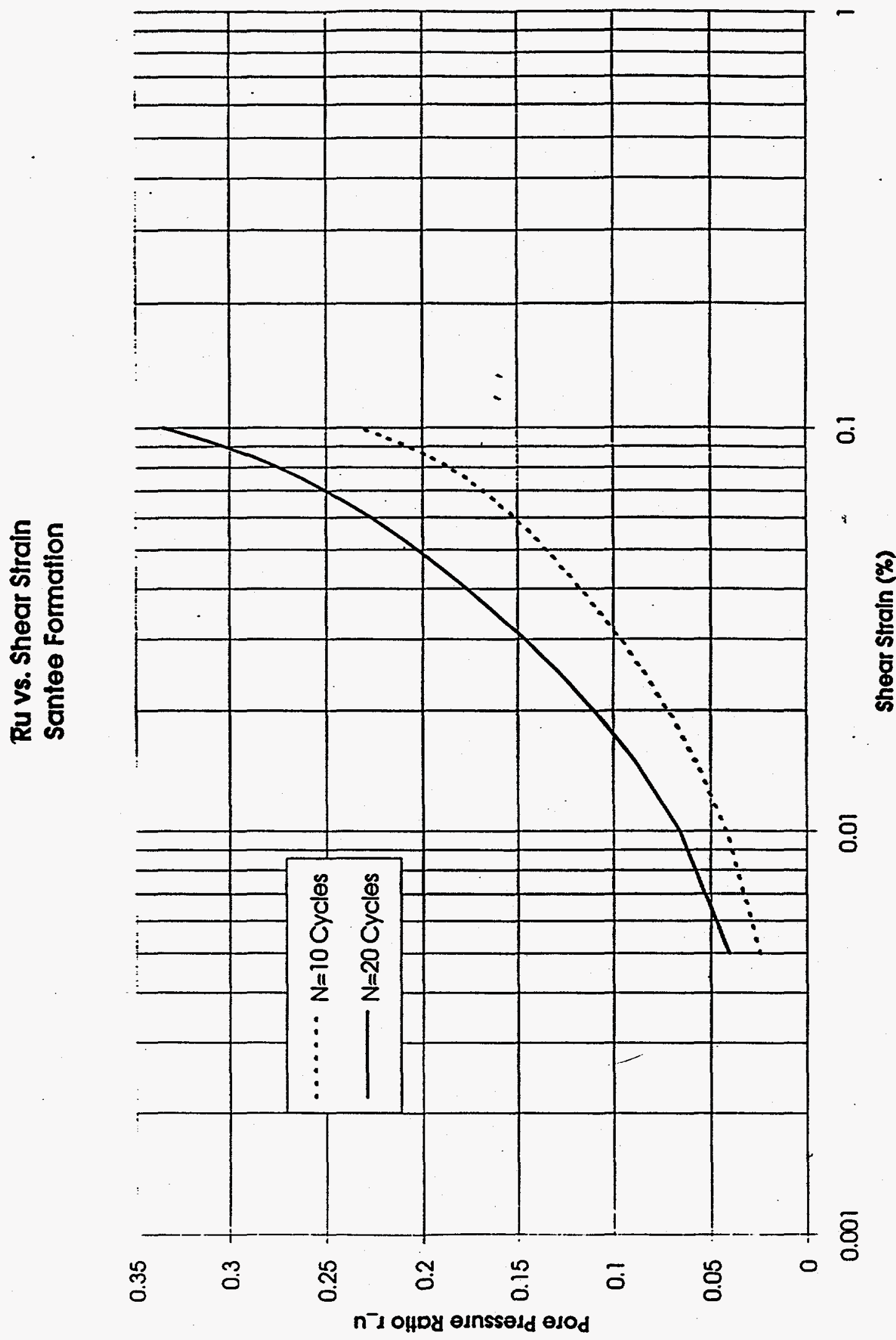



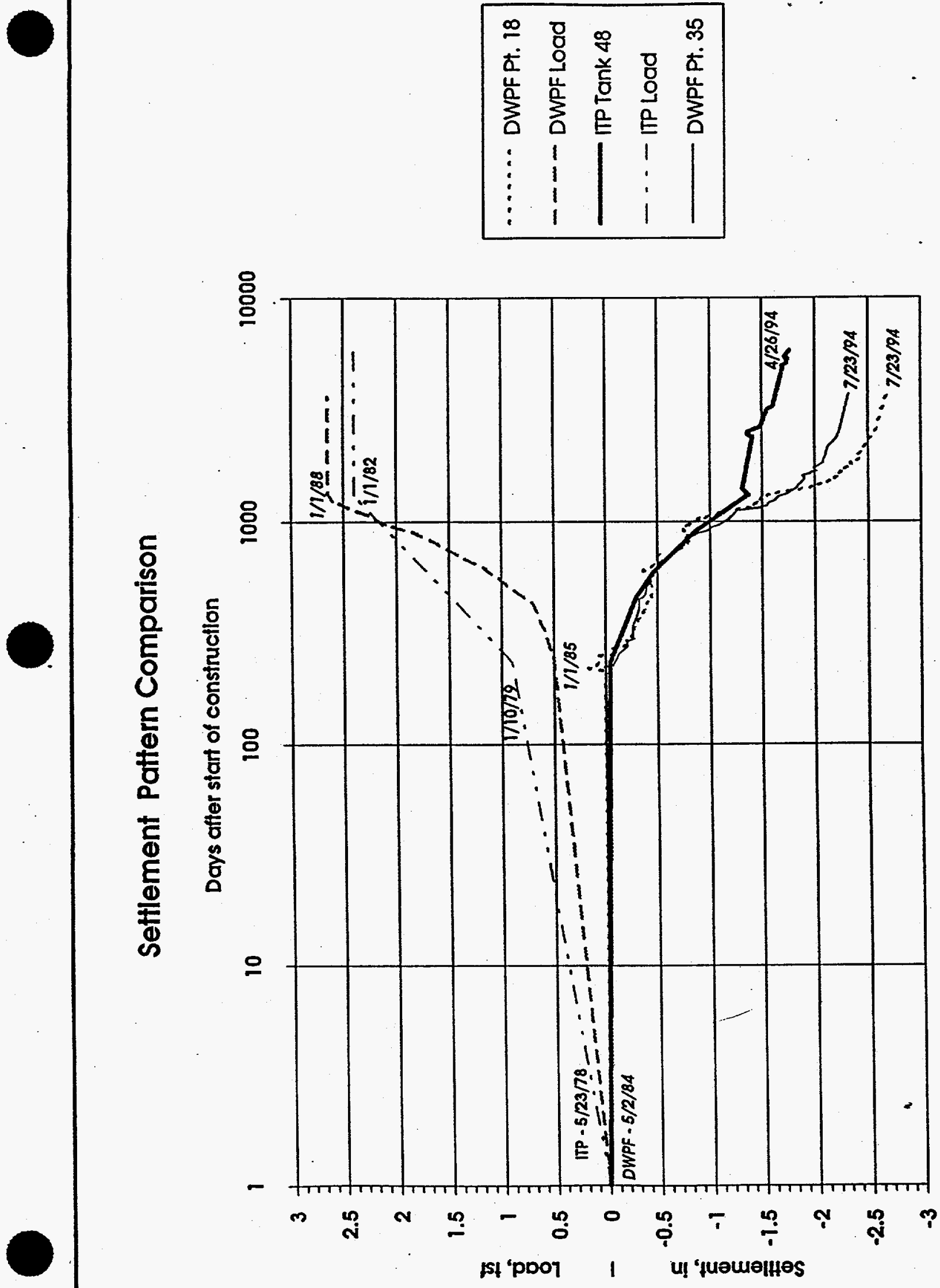

 


\section{TANK 51}

TANK 49

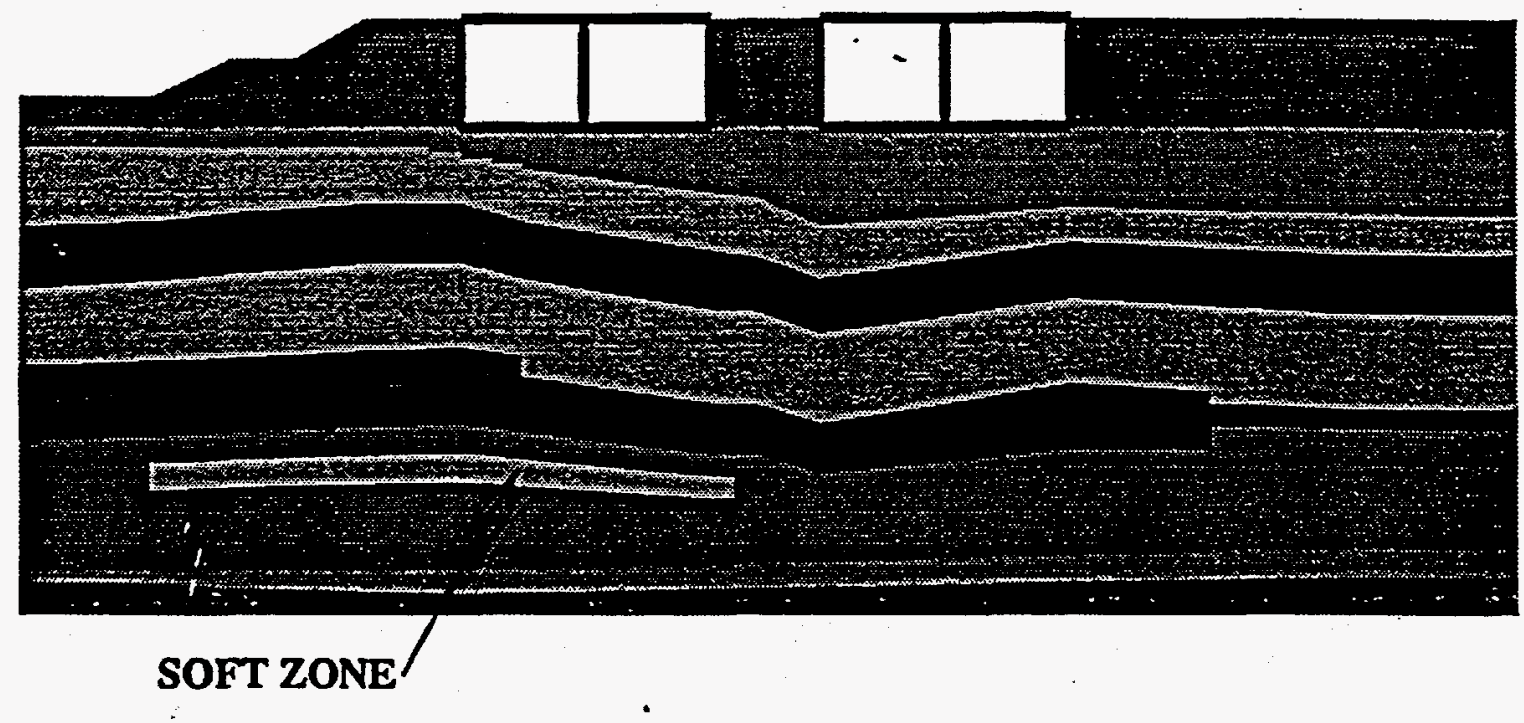

Figure 7-15 ITP "Soft Zone" Subsurface Profile A - A' 


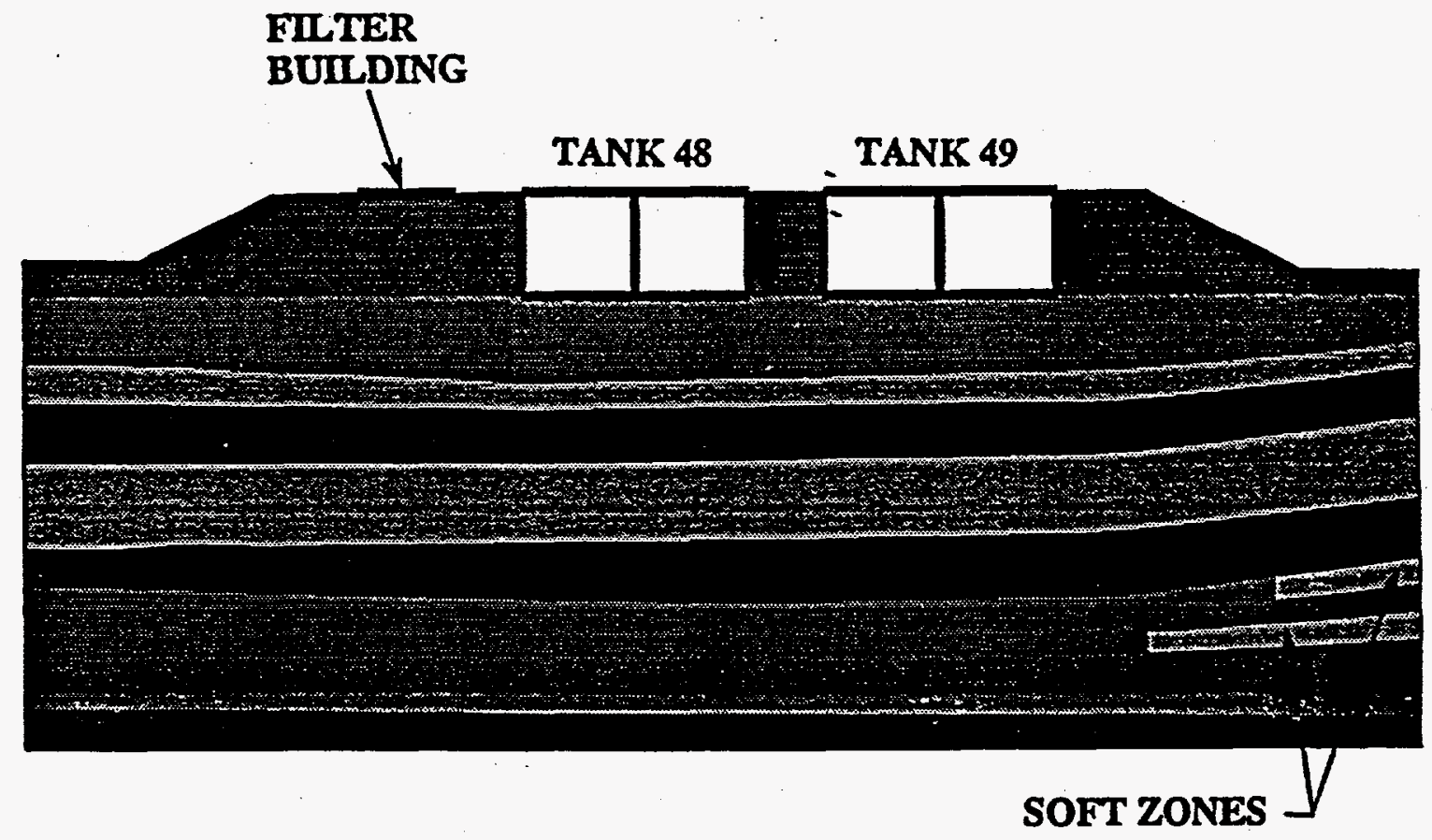

Figure 7-16 ITP "Soft Zone" Subsurface Profile B - B' 


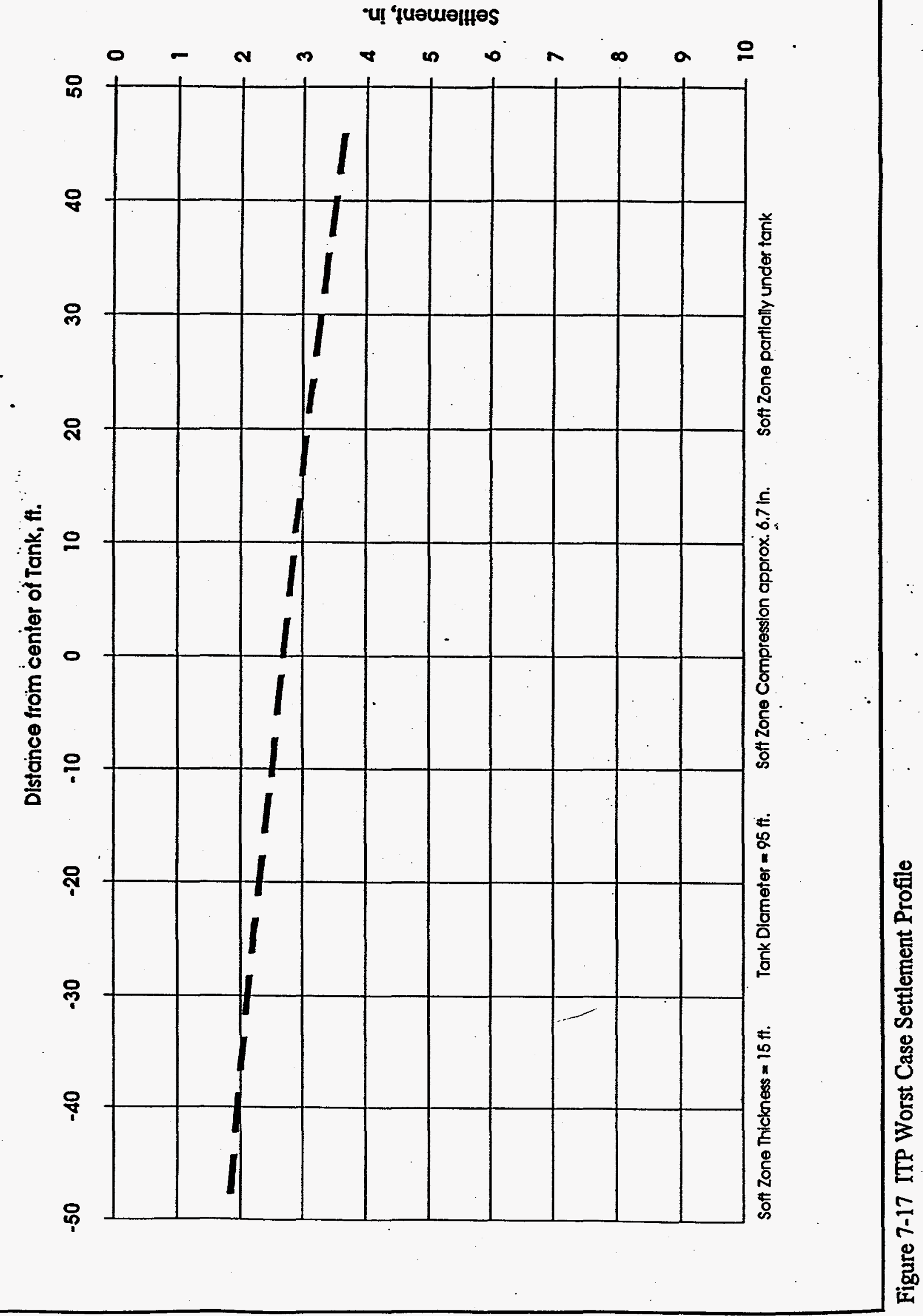

